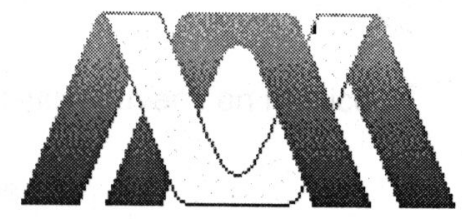

Casa abierta al tiempo

UNIVERSIDAD AUTÓNOMA METROPOLITANA

UNIDAD IZTAPALAPA

DIVISIÓN DE CIENCIAS SOCIALES Y HUMANIDADES

POSGRADO EN CIENCIAS ANTROPOLÓGICAS

Tramas de sentido y juegos tácticos en el tránsito institucional (no carcelario) de jóvenes "delincuentes".

Un acercamiento antropológico al higienismo contemporáneo.

Marta Vencesloa Pueyo

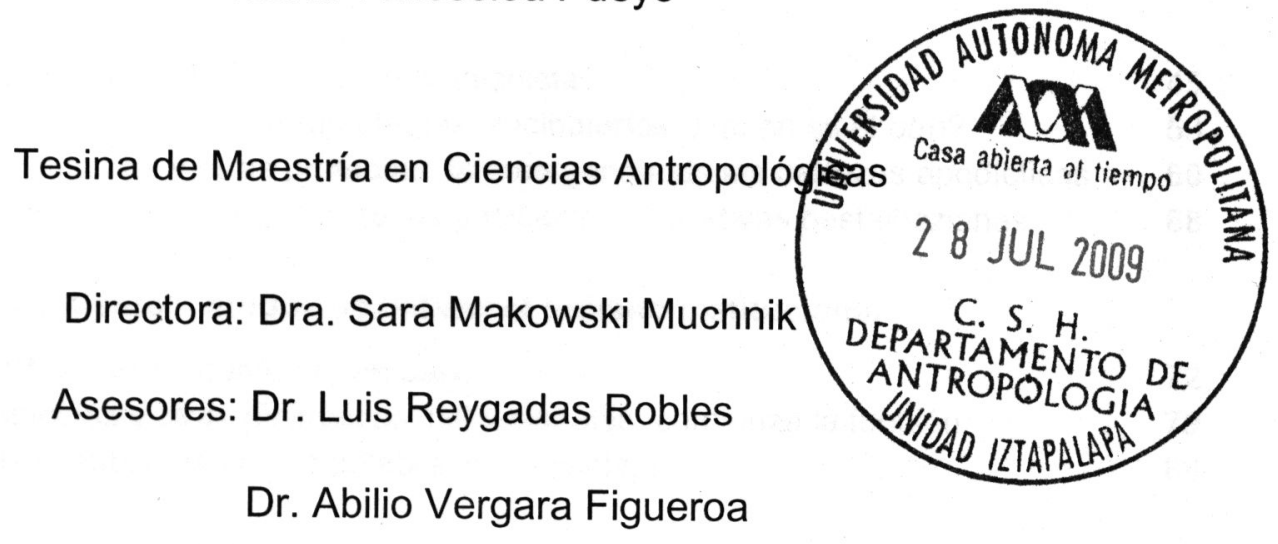




\section{NOTAS PRELIMIARES}

I. Antecedentes históricos de la Justicia Juvenil en México $\quad \mathbf{5}$

$\begin{array}{lr}\text { II. Presentación institucional } & \mathbf{8}\end{array}$

$\begin{array}{lr}\text { III. Consideraciones metodológicas } & 10\end{array}$

\section{CAPÍTULO I HORIZONTE DE ÉPOCA}

I.a. El poder de las clasificaciones: el "excluido" como desviado contemporáneo

I.a.1. La construcción de la alteridad

I.a.2. La función clasificatoria y los efectos del estigma

I.a.3. Las taxonomías de la desviación como dispositivos coadyuvantes a la construcción del orden social

I.a.5. "Exclusión social" como categoria discursiva de la desviación contemporánea

I.b. Universo concetracionario y "exclusión social": la gestión diferencial de ciertas poblaciones

I.b. 1. Introducción a las categorías homo sacer y nuda vida

I.b. 2. Otorgar un estatuto especial: la categoría "exclusión social"

\section{CAPÍTULO II TRAMAS DE SENTIDO Y JUEGOS TÁCTICOS EN EL TRÁNSITO DE JÓVENES “DELINCUENTES”: \\ DRAMATURGIAS, RESISTENCIAS Y SUBJETIVACIONES}

II.a. Instituciones de "reinserción" y "prevención" social: inventarios para la ortopedia moral

II.a.1. Marcas contemporáneas del discurso neohigienista

II.a.2. La ilusión del sujeto perspicuo y sus efectos alucinatorios: ¿quién es el otro?

II.a.3 Premoniciones, augurios y otras profecias: la emergencia de las certezas apodícticas

II.a.4. El "déficit" del otro pobre: el regreso de las posiciones educativas pestalozzianas

Il.b. Jóvenes "en tratamiento": modos de habitar el tránsito institucional

II.b.1. Umbrales: el "tratamiento" como rito de paso

II.b.2. Tácticas, resistencias y otras picarescas institucionales: comienza la función

II.b.3. Cartografías de la subjetivación: la palabra como anclaje

CAPÍTULO III

\section{EL TRABAJO SOCIAL EDUCATIVO COMO ANTI-DESTINO}

CAPÍTULO IV

PALABRAS FINALES...

8

(1)


"El infierno de los vivos no es algo por venir; hay uno, el que ya existe aquí,

el infierno que habitamos todos los días, que formamos estando juntos.

Hay dos maneras de no sufrirlo. La primera es fácil para muchos: aceptar el infierno y volverse parte de él hasta el punto de dejar de verlo. La segunda es arriesgada y exige atención y aprendizaje continuos: buscar y saber reconocer quién y qué, en medio del infierno, no es infierno, y hacer que dure, y dejarle espacio.

ÍTALO CALVINO

\section{INTRODUCCIÓN}

Ésta es una investigación antropológica que, incardinada en coordenadas pedagógicas, aborda la práctica reformatoria inscrita en el trabajo social educativo dirigido a aquellos que el discurso de época ha dado en llamar "excluidos sociales", nuestros anormales contemporáneos. Con este fin, exploramos el tránsito institucional (no carcelario) de jóvenes que cumplen medidas penales alternativas (MPA) en una entidad que trabaja para la "prevención del delito" y la "reinserción" de "menores infractores" en la Ciudad de México. Inscrito en el entramado de la justicia juvenil, este centro realiza intervenciones "psicoeducativas" para la recalificación de "adolescentes de conducta antisocial", lo que la ley tipifica como "tratamiento externo" o "en externación".

Al mismo tiempo, y de forma ineludible, este trabajo se adentra en el análisis extenso de los procesos de construcción y conducción de esos otros desviados y anormales, y de su profuso correlato taxonómico. Se trata de un recorrido preliminar a través de las arquitecturas que hacen posible la producción y el tratamiento del "excluido social" en su tránsito por los complejos entramados institucionales de la reeducación, o lo que es lo mismo, de la corrección moral.

Articulamos los principales interrogantes que suscitaron la presente investigación en torno a dos objetos de estudio: 
1. La labor "reeducadora" de la institución: ¿Desde qué lógica operan este tipo de entidades? ¿Cuáles son las conexiones del discurso y la práctica de la "prevención" con las viejas premisas higienistas? ¿Qué se pretende con la "reinserción"? ¿Cómo son concebidos los jóvenes que atienden? ¿Brinda este tipo de dispositivos la posibilidad de construir nuevas aperturas y filiaciones con lo social a los jóvenes que las habitan?

2. Las tramas de sentido que los jóvenes construyen en su tránsito institucional por dispositivos sociales de este tipo: ¿Cómo habitan estos recorridos? ¿Cómo modula su experiencia la propedéutica reformatoria de la institución? ¿Y la entrada al entramado de la justicia juvenil? ¿Qué recursos y estrategias elaboran para manejarse en dispositivos como el estudiado?

Arrojar luz sobre estos interrogantes supone la necesidad -y fundamentalmente el deseo- de poner a dialogar dos disciplinas: la antropología y la pedagogía social. Dos discursos diferentes que, interconectados en nuestro objeto de estudio, aportan su especificidad de lectura, no como importación de una en la otra, sino como contribuciones genuinas que nos permiten un abordaje poliédrico del fenómeno. Sin embargo, cabe precisar la pregunta: ¿qué de lo particular de la antropología, posibilita la reflexión sobre la práctica del trabajo social educativo?

En "Las ciudades invisibles" Marco Polo insta al Gran Kan a discernir qué es infierno de lo que no lo es, para hacerlo perdurar y abrirle un espacio. La antropología, con su utillaje etnográfico, nos permite describir, explorar, analizar, interrogar las prácticas institucionales y las significaciones que estructuran la experiencia de los jóvenes que las habitan. Pertrechos ineludibles en la tarea de desenmascaramiento de las metamorfosis y los disfraces del universo concentracionario contemporáneo (Agamben, 2006:156), ese infierno a veces invisible que la antropología, avezada en el estudio de lo no aparente, permite vislumbrar. Hoy, nos alerta Núñez (2005), ese espacio biopolítico se traviste en el 
discurso higienista de la "prevención social", y se despliega en los dispositivos de gestión y control de ciertos sectores poblacionales: las "nuevas clases peligrosas".

Si la antropología nos ayuda a discernir lo que es infierno, de lo que no lo es, la pedagogía social -en el marco de esta investigación- posibilita la apretura y pervivencia de espacios que, lejos del averno, restituyan el derecho de todo ser humano a filiarse al entramado social y cultural de su época. Esta disciplina toma como objeto de estudio las prácticas sociales educativas ${ }^{1}$, permitiendo su análisis, crítica y trasformación, dando centralidad a aquello que, desde otros discursos, aparece como "resto". (Núñez, 2004a:110)

Entroncados en la pedagogía social, nos aproximamos a otro de los propósitos que alberga esta investigación: esbozar un modelo de trabajo educativo posible para la atención a jóvenes que atraviesan situaciones altamente complejas. Este propósito reside en el deseo de contribuir a saldar la deuda simbólica de protección, hospitalidad y cuidado que los adultos contraemos con las nuevas generaciones. Esa responsabilidad que Hannah Arendt (1996) definió bellamente como deuda de vida. Esto es, pensar qué modelos institucionales pueden devenir plataformas sólidas de anclaje en la implacable corriente de la modernidad líquida (Bauman, 2002). Amarres que, lejos de fijar a estos jóvenes en el lugar de "resto" a segregar, supongan resortes que les permitan emprender nuevas e inesperadas búsquedas sociales y culturales hacia lugares altamente estimados...

\section{Cuaderno de bitácora}

Hablar de jóvenes "problemáticos", "delincuentes", "infractores", "antisociales", "marginales", etc., nos remite al estudio de la negatividad de aquellos que representan la zona de sombra y oscuridad de toda sociedad, y como apuntamos con anterioridad, al entramado de las imprescindibles taxonomias sociales que legitiman las intervenciones reformatorias sobre el "excluido social". De esta

\footnotetext{
${ }^{1}$ Aquellas que se despliegan en múltiples espacios sociales.
} 
manera, el primero de los tres nudos que conforman la investigación, examina con detenimiento la construcción del "excluido" como desviado contemporáneo y su tratamiento biopolítico en los espacios concentracionarios encubiertos en determinadas prácticas del trabajo social.

En el segundo nudo abordamos las líneas medulares de la investigación. La inmersión en lo tangible propia del trabajo etnográfico nos permite elucidar las formas de intervención de los dispositivos reeducadores y los modos en que los "menores infractores" los habitan, corporeizando algunos de los supuestos planteados -en términos generales- en el capítulo anterior.

La tercera y última parte plantea de manera sintética (no podemos olvidar que el marco de esta investigación es antropológico) una propuesta de trabajo social educativo con jóvenes, en la que se esbozan algunas de las premisas básicas para construir modos de hacer que, sostenidos en el derecho de todo sujeto a formar parte del entramado de su época, se desarrollen junto con los chicos que transitan las instituciones en las que trabajamos (y no sobre ellos), posibilitando las construcción de nuevos y valiosos anclajes sociales y culturales.

Antes del abordaje a los tres nudos planteados se imponen algunas precisiones de orden jurídico, institucional y metodológico, que recogemos sintéticamente en el siguiente apartado. 


\section{APUNTES PRELIMINARES}

\section{Antecedentes históricos de la Justicia Juvenil en México}

La ciudad de San Luis Potosí acogió en 1923 el primer Tribunal de Menores de México. Tres años después, en 1926, se crea un juzgado similar para el Distrito Federal. Este incipiente sistema de justicia especializado abocó sus primeros esfuerzos en justificar la necesidad de otorgar una atención particular a niños y adolescentes "infractores", alejada de la rigidez penal a la que eran sometidos los adultos.

En 1928 se promulga la Ley de Prevención Social de la Delincuencia Infantil en el Distrito Federal y territorios federales (conocida como Ley Villa Michel). Esta ley instó al Estado, auxiliándose de instituciones de beneficencia, a eliminar la delincuencia infantil corrigiendo las perturbaciones físicas y mentales de los menores, y evitando un medio familiar deficiente.

En 1941 se crea la Ley orgánica y Normas de Procedimiento de los Tribunales de Menores y sus Instituciones Auxiliares, que puso en primer plano la necesidad de reeducar a los “menores delincuentes". Ésta fue reformada en 1971, creándose la Dirección General de Servicios Coordinados de Prevención y Readaptación Social.

En 1974 se instaura la Ley que permitió instaurar los primeros Consejos Tutelares para Menores Infractores del Distrito Federal (Jiménez, 2009), dispositivos que han sobrevivido hasta la fecha. Su principal propósito fue promover la readaptación social de aquellos que, siendo menores de dieciocho años ${ }^{2}$, infringían leyes penales, reglamentos de policía y buen gobierno, o manifestaban alguna otra forma de conducta que hiciera presumir inclinaciones a causar daños a sí mismo, a su familia o a la sociedad. El Consejo estableció dos formas de

\footnotetext{
${ }^{2}$ En 1931 se estableció la mayoría de edad penal en los dieciocho años.
} 
actuación: una correctiva, cuando el menor ha infringido disposiciones legales, y otra preventiva, cuando su conducta hace presumible el que cause un daño. En los supuestos referidos, el Consejo intervenía mediante el estudio de la personalidad, llevando a cabo la realización de estudios médicos, psicológicos, pedagógicos y sociales, así como, la aplicación de medidas correctivas y de protección a la vigilancia del tratamiento.

El siguiente momento a señalar es 1991, cuando se instituye la Ley para el Tratamiento de Menores Infractores para el Distrito Federal, en Materia Común, y para toda la República, en Materia Federal. (DOF, 24 de diciembre de 1991) Su objeto fue reglamentar la protección de los derechos de los menores, y lograr la "adaptación social" de los "infractores" mediante la implementación de medidas de orientación, protección y tratamiento. Se determinó la edad de responsabilidad penal para los mayores de once años y los menores de dieciocho.

Cabe subrayar que el marco legal desarrollado hasta el momento consolidó la coparticipación de organizaciones civiles, a través de la firma de convenios interinstitucionales, en algunas de las tareas del Sistema de Justicia Juvenil. Asimismo, y en lo que respecta a los derechos de los niños, México se adscribió a las disposiciones de carácter internacional que consignan estos derechos, integrándolos en el Derecho Positivo mexicano. ${ }^{3}$

En 2006 se instaura el Sistema Integral de Justicia de Adolescentes para la Federación, los Estados y el Distrito Federal (de donde se deriva la actual Ley de Justicia para Adolescentes para el Distrito Federal del 14 de noviembre de 2007), aplicado a quienes se atribuya la realización de una conducta tipificada como delito por las leyes penales, y tengan entre doce y dieciocho años de edad. El Sistema Integral de Justicia trata de garantizar los derechos fundamentales que

\footnotetext{
3 Nos referimos a la Convención sobre los Derechos del Niño, 1989; Reglas mínimas de las Naciones Unidas para la Administración de la Justicia de Menores, 1985; Reglas de las Naciones Unidas para la protección de los menores privados de libertad, 1988-1989; Reglas mínimas de las Naciones Unidas sobre las medidas No privativas de la libertad -Reglas de Tokio-, 1990.
} 
reconoce la Constitución mexicana para todo individuo, así como aquellos específicos atribuidos a los menores de edad. La procuración e impartición de justicia para adolescentes está a cargo de las instituciones, tribunales y autoridades especializados para cada orden de gobierno, y se podrán aplicar medidas de orientación, protección y tratamiento, atendiendo a la protección integral y el interés superior del menor. Las formas alternativas de justicia deberán observarse en la aplicación de este sistema, siempre que resulte procedente. Se señala asimismo que las medidas deberán ser proporcionales a la conducta realizada y tendrán como fin la reintegración social y familiar del adolescente, así como el pleno desarrollo de su persona y capacidades. El internamiento se utilizará sólo como medida extrema y por el tiempo más breve que proceda, y podrá aplicarse únicamente a los adolescentes mayores de catorce años de edad, por la comisión de conductas consideradas "antisociales graves". (Castellanos, op.cit.)

Es importante señalar que la ley actual, en lo que concierne a las medidas de tratamiento externo, pondera a los padres o tutores de los "infractores" como los principales responsables en la consecución de los objetivos de la reintegración, exigiendo su activa participación en el cumplimiento de la pena. La familia es concebida como factor determinante en el proceso de socialización del menor ( $y$ en su fracaso), así como en los intentos de re-socialización. El tratamiento en externación busca la integración del "menor" en su medio sociofamiliar.

Estas Medidas Penales Alternativas se inscriben en las corrientes de la prevención general positiva de derecho penal, que trata de reducir la aplicación de penas en prisión, y acercar al "infractor" a "acciones de reparación con el ánimo de que viva en sintonía con los principios de la convivencia humana”. (Castellanos, op.cit.) Su punto medular se articula en torno al tratamiento del delincuente para alcanzar su "reeducación", y por ende, su "reintegración". Nos referimos a la intervención directa en su personalidad, entorno familiar, vínculos y habilidades sociales a través de la aplicación de métodos psicosociales y educativos que influyan en su sistema de valores. 


\section{Presentación institucional}

La institución estudiada se define como una entidad independiente de toda filiación política, religiosa ${ }^{4}$ o económica, que tiene como "misión" principal la "prevención de conductas delictivas" y la "reinserción de menores infractores", contribuyendo así a la consecución de uno de sus objetivos secundarios: el "mejoramiento de la seguridad pública". Fundada en el año 1982, cuenta con el reconocimiento de la Dirección General de Prevención y Tratamiento de Menores (órgano dependiente de la Secretaría de Seguridad Pública del Gobierno Federal Mexicano) desde 1993, lo que le ha permitido introducirse en los engranajes del circuito de la justicia juvenil del Distrito Federal al alcanzar el estatuto de "institución auxiliar" para la aplicación de medidas de "tratamiento externo". El equipo de "operadores", curioso significante con el que los profesionales de la institución se autorefieren, está conformado por un total de doce psicólogos, trabajadores sociales y abogados, que atienden a un promedio de ochenta jóvenes por año.

A través de un convenio con la DGPT, desarrollan las medidas de "tratamiento externo" contempladas en la Ley de Justicia para Adolescentes para el Distrito Federal del 14 de noviembre de 2007, esto es, acciones "reeducativas" dirigidas a los "infractores" (y sus familias) implementadas en instituciones (no carcelarias) especializadas. Asimismo, proporciona asesoría y defensa legal gratuita a los acusados.

Hemos señalado que el "tratamiento en externación" es una alternativa a la privación de libertad para los "menores primodelincuentes" que cometieron una infracción "no grave". Esta medida considera que el "menor debe vivir en su medio social y familiar bajo el cuidado de sus padres", manteniendo la obligación de presentarse a recibir "tratamiento" en los días y las horas especificados por la

\footnotetext{
${ }^{4}$ Sin embargo, el vestíbulo de la institución está presidido por un crucifijo de dimensiones considerables, los profesionales aluden a dios en sus interacciones con los chavos, y durante los cuatro meses de trabajo de campo, los jóvenes y sus familias fueron convocados a varias misas oficiadas por un cura en la entidad (Navidad, inauguración de ampliación de las instalaciones del centro y 25 aniversario de la institución).
} 
institución (no más de veinte horas semanales). Este tipo de penas tienen una duración mínima de 6 meses y máximo de 12 meses $^{5}$, y el no cumplimiento por parte del joven comporta (una vez la entidad da parte a las autoridades judiciales), la revocación de la MPA y el ordenamiento de "tratamiento en internación", así como el encierro durante 72 horas del familiar-tutor responsable del "menor".

El primer contacto del joven con la institución se produce durante su detención en el Consejo de Menores (CM) ${ }^{6}$. Los psicólogos y trabajadores sociales se encargan de "captar", "diagnosticar" y "seleccionar" a los chavos que cumplen con los requisitos de acceso fijados por la entidad. Es útil trascribirlos en su literalidad:

a) Ser primoinfractores (entre 12 y 18 años). Esto responde a una lógica de prevención y a un porcentaje mayor de éxito en la reintegración. ${ }^{7}$

b) Tener disponibilidad y compromiso para participar en el tratamiento. ${ }^{8}$

c) Que los padres de familia o responsables legales del menor estén dispuestos a participar en los programas de la institución y tengan disposición al cambio [sic].

d) Pertenecer a población de escasos recursos o a algún grupo étnico marginado.

e) Presentar consumo de drogas en nivel experimental y/o funcional.

f) No estar bajo tratamiento médico farmacológico

Elegido el menor (y su familia), comienza el "procedimiento jurídico", donde los abogados de la entidad asumen la defensa del caso, y la asesoría legal a los familiares. Si el fallo judicial dictamina una medida de "tratamiento en externación", el joven comenzará el recorrido por la institución propiamente dicho. Éste consta de tres etapas: "recepción", "tratamiento" y "seguimiento".

\footnotetext{
${ }^{5}$ La mayoría de los chicos cumplen penas no inferiores a un año.

${ }^{6}$ Este periodo de encierro carcelario tiene una media de entre 3 y 4 meses de duración en el cual el Ministerio Público realizan las averiguaciones sobre el caso. Finaliza una vez que el juez dictamina la sentencia para el "menor": libertad, tratamiento en externación, o tratamiento en internación.

${ }^{7}$ Y podríamos añadir que atiende también a las posibilidades de éxito de conseguir que el juez falle a favor de una medida de tratamiento externo.

${ }^{8}$ Interesante eufemismo para referirse a la obligatoriedad de la asistencia.
} 
1. Recepción: abarca las primeras semanas del tránsito en el que los profesionales, mediante entrevistas, completan el diagnostico (iniciado durante el encierro en CT) sobre los "aspectos de la personalidad" y la "dinámica familiar". En este etapa inicial se establece también el "pronóstico" en el tratamiento tomando en cuenta los grados de "funcionalidad y de compromiso", así como el tratamiento a seguir.

2. Tratamiento: gravita principalmente en lo que los profesionales de la entidad llaman acciones "psico-pedagógico-educativas", conformadas por intervenciones grupales estructuradas en módulos temáticos ${ }^{9}$, así como por intervenciones individuales "psicoterapéuticas" destinadas a trabajar las "causas de la infracción", el "manejo de límites" y el "entorno familiar y social".

3. Seguimiento: a pesar de que está contemplado en el procedimiento, en la práctica no se lleva a cabo. Una vez concluida la MPA, los profesionales pierden el contacto con los jóvenes, quedando obturada la posibilidad de saber si el tratamiento logró sus principales objetivos: la "reinserción" y la "no-reincidencia".

A esta arquitectura institucional debemos añadirle el espacio académico (foráneo) de INEA (Instituto Nacional de Educación de Adultos), que cuenta con un aula para impartir clases a aquellos jóvenes cuya condena contemple la obligación de concluir los estudios de primario o secundaria. Las clases, dirigidas por voluntarios de INEA, se realizan una vez a la semana durante cuatro horas.

\section{Consideraciones metodológicas}

La aproximación etnográfica al objeto de investigación se realizó en la institución durante los meses de diciembre y noviembre de 2008, y enero y febrero de 2009. La estrategia metodológica se articuló en tres momentos consecutivos, en los que se utilizaron diversas técnicas:

\footnotetext{
9 Violencia intrafamiliar, adicciones, autoestima, valores, comunicación, sexualidad y realidad social, referida esta última a la identificación de "las problemáticas en las que se vive a nivel familiar y social".
} 


\section{Primera etapa}

Consulta del material publicado por la institución sobre conceptualizaciones y metodología de intervención en el trabajo reeducativo con "jóvenes problemáticos" (corpus teórico que orienta la práctica de los profesionales).

\section{Segunda etapa}

Entrevistas individuales semi-abiertas a seis "operadores" que participan activamente en las etapas de "recepción" y "tratamiento". Esta herramienta nos permite una aproximación a cuestiones tan medulares como las concepciones que los profesionales tienen de los jóvenes que atienden, la noción de encargo institucional y la tarea reeducadora, el aparato conceptual que orienta su práctica, entre los más importantes.

Los "operadores" entrevistados fueron tres psicólogas, un/a trabajador/a social, una abogada con experiencia en la atención a "menores infractores" que oscila entre doce y trece años.

Entrevistas individuales semi-abiertas a diez jóvenes. Chavos varones ${ }^{10}$ entre quince $y$ dieciocho años procedentes de las delegaciones Iztapalapa, Cuauhtémoc, Gustavo A. Madero y Venustiano Carranza. Ninguno de los entrevistados ha concluido los estudios de secundaria (tres de ellos tampoco concluyeron la primaria), y, a excepción de dos, el resto trabajan permanente o esporádicamente en la economía informal. Su origen y situación socioeconómica actual es en todos los casos desfavorable y precaria.

Las entrevistas estuvieron orientadas a acercarnos a aspectos tales como los modos de habitar la institución, sus percepciones sobre el tratamiento y el intento de corrección por parte de los "operadores", los efectos del estigma y las resistencias desplegadas ante la atribución de una identidad deteriorada.

\footnotetext{
${ }^{10}$ A pesar de que la atención está dirigida a chicos y chicas, la proporción de estas últimas con respecto al número de varones no alcanza el $2 \%$. En el momento del trabajo etnográfico no se atendió a ninguna mujer.
} 


\section{Tercera etapa}

Observación directa no obstrusiva en espacios de trabajo individual (chavooperador y chavo-familiar-operador) y en espacios grupales (grupo de desarrollo humano), con el propósito de registrar, describir y analizar las interacciones jóvenes-profesionales y jóvenes-jóvenes (roles, jerarquías, relaciones de poder, actuaciones, códigos, intercambios, camaraderías...)

De forma transversal

La aproximación etnográfica se urdió a su vez con los hilos de una atención perspicaz a los "entre pasillos", las sobremesas con los profesionales, los lapsus, los descuidos, las miradas... y todo ese abigarrado cuerpo informe de hechos locuaces que nos acercan, tal vez de forma más diáfana, a nuestro objeto de estudio. 


\section{CAPÍTULO I \\ HORIZONTE DE ÉPOCA}

\section{I.a. EL PODER DE LAS CLASIFICACIONES: EL "EXCLUIDO SOCIAL" COMO DESVIADO CONTEMPORANEO}

Dios habría podido hacer ricos a todos los hombres, pero quiso que hubiera pobres en este mundo para que los ricos tuvieran ocasión de redimir sus pecados.

LA VIDA DE SAN ELOY

\section{I.a.1. La construcción de la alteridad}

Prostitutas, drogadictos, delincuentes, reclusos, jóvenes inadaptados, vagabundos, alcohólicos... Este es, presumiblemente, el núcleo del llamado campo de la "desviación": los desviados sociales. Gente a quien se considera comprometida en cierto tipo de rechazo colectivo del orden social; aquellos percibidos como incapaces de utilizar las oportunidades del progreso existentes en los diversos caminos aprobados por la sociedad. (Goffman, 2003:166) Seres que dejamos de ver como personas totales y corrientes, para reducirlas a seres inficionados y menospreciados. (op.cit.:12) La alteridad, encarnada en la figura del "desviado", nos remite a un sistema de representaciones que asigna al otro una suerte de rasgos negativos que lo harán portador de un estigma. ${ }^{11}$ Estos otros, máximos exponentes de la degradación moral y social, serán ubicados en categorías sociales hacia cuyos miembros se genera todo tipo de respuestas negativas. Violencias físicas y simbólicas legitimadas en la naturaleza diferente del estigmatizado, cuya identidad deteriorada autoriza a reducir su humanidad, con consecuencias que pueden ir desde la invalidación social en sus múltiples y

\footnotetext{
11 Estos rasgos negativos, nos dice Gallén (2006:12), pueden ser completamente fantasiosos, encontrando precisamente en su naturaleza imaginaria la clave de su irrevocabilidad.
} 
multiplicadas modalidades (encierro, destierro, repudio, conmiseración, etc.), hasta el exterminio, la muerte.

La antropología privilegia y se define en torno al estudio de la categoría fundamental de alteridad. (Krotz, 2007:160) Desde nuestra disciplina se han realizado importantes aportes -empíricos y conceptuales- en la descripción y evaluación de los procesos de producción de identidad y de todo lo que la hace posible. La ciencia antropológica ha mostrado su pertinencia en el estudio de la negatividad de los seres que representan la zona de sombra, de oscuridad y desorden de toda sociedad. Al mismo tiempo ha mostrado que los otros, los extraños, lejos de ser un fenómeno natural, son un producto de dinámicas sociales e ideologías. Es siempre el resultado de una determinada y concreta relación sociohistórica y situacional. Como sostiene Santamaría (2002:7), es el efecto de la relación social entre dos heterogeneidades: relativa (los otros siempre son los otros de un heterogéneo nosotros) y relacional (los otros de un nosotros son un nosotros que nos ve como otros).

Presentamos en este espacio preliminar algunas reflexiones en torno a la siguiente premisa: las taxonomías de la desviación remiten a poderosos y abigarrados sistemas de clasificación mediante los cuales se distinguen y distribuyen los diferentes grupos estigmatizados, quedando, en mucho casos, apresados en categorías estancas de las que no les resultará fácil zafarse. Los procesos de etiquetamiento, nos advierte Melossi (citado en Larrauri, 2000:138), no son sólo procesos nominalistas, sino formas de gobernar los actos y controlar la realidad. Asimismo, argumentamos que la categoría de época "excluido social" deviene una modalidad contemporánea de nombrar, clasificar y operar sobre los sujetos desviados. 


\section{I.a.2. La función clasificatoria y los efectos del estigma}

Las inestimables aportaciones realizadas por Durkheim y Mauss en su trabajo "Sobre algunas formas primitivas de clasificación" (1996 [1901]) nos permiten arrojar luz sobre la importancia que la función clasificatoria tiene en la construcción y mantenimiento de todo orden social, pues se trata de operaciones imprescindibles para dotar de significación y legibilidad al mundo, haciendo posible la vida social. Estos autores se interrogan acerca de qué es lo que lleva a los seres humanos a disponer sus ideas en sistemas clasificatorios, y en qué sustrato se encuentra "el plan de tan profunda disposición". (op.cit.: 31) Al hilo de estas cuestiones, apuntan que la función clasificatoria estriba en agrupar seres, acontecimientos y hechos del mundo y ordenarlos en grupos diferentes entre sí, separados por límites claramente definidos. Clasificar cosas o seres no significa únicamente construir categorias, implica también disponerlas en base a relaciones de inclusión y exclusión. $Y$ es que toda clasificación entraña un orden jerárquico que, lejos de ser un producto espontaneo, refracta el orden social de un determinado grupo. En palabras de los autores, "la clasificación de las cosas reproduce la clasificación de los seres humanos" (op.cit.: 33), esto es, existe una correspondencia entre las estructuras sociales y el orden mental; una suerte de homogeneidad entre sociedad y universo, en donde éste sería una reverberación de la estructura social.

Delgado (2007) sostiene que la actualidad del ensayo de Durkheim y Mauss sobre las clasificaciones primitivas nos conduce a apreciar cómo nuestra propia sociedad hace inteligible la racionalidad que emplea para clasificar, distribuir, distinguir, separar y jerarquizar por grupos categoriales los objetos tanto humanos como materiales que la conforman. Para estos autores [Durkheim y Mauss], la acción de clasificar, como apuntábamos anteriormente, no es espontánea ni responde a una necesidad natural del ser humano. Por un lado, éste no pudo encontrar en sí mismo los elementos esenciales de la clasificación, y por otro, "las cosas no se presentan ellas mismas así agrupadas a la observación". (Durkheim y 
Mauss, op.cit.:30) Siguiendo los planteamientos de Delgado (op.cit.:200), estas indicaciones nos permiten proponer que no es la visibilidad de las diferencias físicas, sociales o culturales las que generan la diversidad, sino que son los mecanismos de diversificación los que motivan la búsqueda de marcajes que llenen de contenido la voluntad de distinguirse y distinguir a los demás, no pocas veces con fines estigmatizadores y excluyentes. "No se clasifica porque haya cosas que clasificar, sino que es porque clasificamos que las podemos descubrir. No es la diferencia la que suscita la diferenciación, sino la diferenciación la que crea y reifica la diferencia"12. (lbíd.)

La tesis de Douglas (1991b) recogida en "Pureza y peligro" también contribuye al propósito de nuestras reflexiones. Para esta autora, la vida en sociedad implica un sistema de clasificación de objetos, personas y relaciones. Todo sistema taxonómico es por definición incompleto; presenta zonas de ambigüedad e indefinición sobre los que gravitan interrogantes, misterios, franjas oscuras... Las anomalías, entendidas como fenómenos perturbadores del orden social que presentan dificultades en el momento de su clasificación, son asociadas con lo contaminante y lo impuro. Aquello que está ubicado en un lugar confuso e incierto vela la delineación de las fronteras simbólicas que distinguen las diferentes categorías sociales.

El "desviado" no ocupa un lugar normalizado en el escenario social, es un personaje ambiguo que presenta irregularidades cuando se lo intenta clasificar. Es percibido como un ser sucio, impúdico, inmoral, cuya presencia resulta incómoda, por lo que se cernirán sobre él todos aquellos mecanismos sociales que protejan e inmunicen a la comunidad estructurada contra las contradicciones y los miedos derivados de la relación con los que amenazan el orden social. En la categoría desviado operan vigorosas estructuras simbólicas que son el reflejo de la estructura social en la que se inscriben. Existe una tenaz demarcación simbólica que distingue lo sucio (el excluido, el desviado y contaminado), de lo limpio (el

\footnotetext{
${ }^{12}$ En un sentido análogo, Barth (1976) sostiene que las fronteras no se trazan para separar diferencias, sino que, por el contrario, al ser trazadas surgen de improvisto las diferencias.
} 
incluido, el normal y puro). Los primeros serán estigmatizados por su impureza y su identidad deteriorada, los segundos, aquellos que tienen el poder de elaborar e imponer los sistemas lógicos de significación, quedarán libres de toda mácula.

En sintesis: los mecanismos de clasificación, y su correlato de nomenclaturas lógico-sociales, son instrumentos cognitivos, al mismo tiempo, que dispositivos de poder y control que ordenan y separan grupos sociales, delineando diferencias y fronteras, a veces inexpugnables. Como ya señalaron Berger y Luckmann (2001), toda etiqueta implica una cierta localización social, esto es, la adjudicación de un lugar concreto en lo social. Al mismo tiempo, y esto es fundamental para nuestro objeto de estudio, constituyen un eficaz artefacto en la asignación de nuevas identidades estigmatizadas. Autores como Goffman (op.cit.), Becker (1971) y Lemert (1967), señalaron que la persona etiquetada, en muchos casos, asimila y reproduce la definición que otros le atribuyen, ajustando su comportamiento a las expectativas asociadas al estatus social asignado (adolescente infractor, joven problemático, loco, etc.). Detengámonos a continuación en los complejos efectos del estigma.

Los teóricos del etiquetaje (labelling approach) ${ }^{13}$ inscritos en la Escuela de Chicago mostraron en la década de los sesenta las implacables consecuencias que la atribución del estigma tiene en los sujetos marcados por signos inferiorizantes. A ellos les debemos el abordaje de los procesos de estigmatización desde el análisis de la relación tripartita entre estigmatizador-estigmatizado-institución.

Para Goffman (2003), uno de los autores que con más penetración abordaron la cuestión, el ser descubierto y calificado como desviado tiene importantes consecuencias para la autoimagen de la persona afectada, así como para su posterior participación social. La consecuencia más importante es un cambio

\footnotetext{
${ }^{13}$ Esta teoría, también conocida como Teoría de la reacción social, está atravesada por dos corrientes sociológicas: el interaccionismo simbólico (inspirado en Mead) y la etnometodología (inspirada en la sociología fenomenológica de Schuz). Becker y Goffman destacan en el ámbito de la reflexión sobre la desviación desde el interaccionismo.
} 
drástico en la identidad pública del individuo, que lo conducirá a ocupar un nuevo estatus y sostener una nueva identidad pública. El sujeto etiquetado como "desviado", "anormal", etc., experimenta una identidad deteriorada, que lo impele a considerarse indigno, inferior, abyecto. Esta identidad, continúa el autor, se proyecta en las interacciones sociales que el sujeto mantiene en su vida cotidiana. De esta manera, aquel que ha sido marcado con un atributo defectuoso, es muy posible que acabe aprendiendo los términos de su inferioridad, esto es, interiorizándolos, significándolos. El clasificado como "joven problemático" acaba inevitablemente convirtiéndose en lo que dicen de él que es, es decir, acaba "problematizándose".

En una línea semejante, Becker (1971), en su inestimable obra "Los extraños", muestra que la consecuencia más importante de la aplicación de una etiqueta consiste en un cambio decisivo de la identidad social del individuo; un cambio que tiene lugar en el momento en el que se introduce en el estatus de "desviado". La etiqueta actuaría a modo de profecía autocumplida, esto es, el definido como "desviado", acaba actuando como tal. El sujeto termina por adoptar la identidad que los demás le atribuyen; se ponen en movimiento una serie de mecanismos que conspiran para conformar al sujeto a la imagen que la gente tiene o espera de él. (op.cit.: 41)

Lemert (1967), otro de nuestros chicanianos sobresalientes, plantea que la reacción social o el castigo a un comportamiento desviado induce a cometer otras desviaciones al generar en el individuo un cambio de la identidad social que lo lleva a desempeñar el papel de acuerdo a la etiqueta que le ha sido asignada. Una de las distinciones centrales en su teoría de la desviación es la que realiza entre delincuencia primaria y delincuencia secundaria. Lemert desarrolla esta separación para mostrar cómo el castigo de un primer comportamiento desviado tiene a menudo la función de instigar al sujeto a la "desviación", generando, por medio de un cambio de la identidad social del individuo estigmatizado, una tendencia a desempeñar el nuevo papel asignado. La desviación primaria es 
definida por el autor (op.cit.: 40) como los actos que el sujeto realiza debido a múltiples factores sociales, psicológicos, biológicos, etc. En la desviación secundaria el sujeto ya no actúa movido por esos factores iníciales, sino guiado por una nueva situación, una nueva identidad creada por la actuación de los órganos de control, como una forma de responder a los problemas originados por esa relación social. Para Lemert las "causas" originales de la desviación se desplazan, como veremos en próximos párrafos, para situar en primer plano la importancia central de la reacciones de desaprobación, degradación y aislamiento de parte de la sociedad.

La tesis lemertiana nos permite impugnar la concepción educativa de las MPA en particular, y de las prácticas de reinserción en general. La intervención del sistema penal-asistencial, en lugar de ejercer un efecto de inclusión social sobre el sujeto considerado como desviado, determinan, en la mayoría de los casos, una consolidación de la identidad de desviado (en nuestro caso, la de "menor infractor") en su presentación social y en su comportamiento. Someter al sujeto a tratamiento y rehabilitación en dispositivos carcelarios, arguye Lemert (op.cit.), contribuye a que el individuo asuma definitivamente su etiqueta de desviado. Las instituciones y agentes de control refuerzan la conducta desviada, por lo tanto son falsos los fines preventivos de la pena y su concepción de reeducación, la cual no puede ejercer un efecto educativo sobre la persona sometida a ella, sino el sufrimiento y la pérdida de las capacidades de reacción de su yo.

Es en este sentido recalificador que voces representativas de la criminología crítica (Larrauri (2000), Baratta (2004), Bergalli, Bustos y Miralles (1983), González Vidaurri y Sánchez Sandoval (2008), entre otros) han cuestionado activamente el proceso penal, argumentando que es precisamente ese recorrido el que contribuye de forma decisiva a la construcción del sujeto "criminal". De Leo (1985:14) lo plantea con una claridad meridiana: "las instituciones de la justicia para los menores son esencialmente un aspecto fundamental de la criminalización de los jóvenes, en el sentido de que su acción desempeña un papel primordial en 
la definición, delimitación, elaboración y producción social e institucional del fenómeno".

Además de señalar que los etiquetados como delincuentes son rechazados por la sociedad, la criminología crítica ha enfatizado vivamente que los procesos de designación pública, conduce a que el propio sujeto asuma una nueva identidad, reordene su personalidad, y se afiance en su nuevo status (de delincuente), distinto del que poseía cuando inició sus actividades delictivas. Se trata de lo que Matza (1981) sintetizó como la "ironía del sistema penal": el proceso penal, supuestamente orientado a disminuir el número de delincuentes, provoca con su proceso público de etiquetamiento que los sujetos que había realizado actos de tipo delictivo asuman esa identidad y actúen posteriormente como delincuentes, que era precisamente lo que se pretendía evitar. Podemos hacer extensible esta ironía a ciertas prácticas del campo social que, marcando una separación rotunda entre incluidos y excluidos, terminan reafirmando la lógica de exclusión que pretendían combatir en la medida en que operan confirmando la mácula de inferioridad de los sujetos que ansiaban "reinsertar" en la vida colectiva.

Las instituciones y los profesionales del campo social son actores fundamentales y necesarios en la producción y refuerzo de las identidades deterioradas que tratamos de analizar. No en vano Becker (op.cit.: 43) sostuvo que el paso definitivo de la carrera de un desvaído consiste en entrar a un grupo desviado organizado, en nuestro caso, entrar en los circuitos institucionales de la justicia juvenil. En este tránsito de interacciones con profesionales y otras personas que comparten el mismo estigma, el sujeto reforzará posiciones, razones, actitudes, etc., en relación a la identidad otorgada.

Veremos en la segunda parte de esta investigación que es necesario que los estigmatizados reciban de ellos mismos la imagen de sujetos sobre los que se debe intervenir, pues cuentan con alguna carencia, desviación o minusvalía que los separa de un modelo de "normalidad" celosamente salvaguardado por los instigadores morales (op.cit.:137), aquellos que se encargan de imponer las reglas, y situar qué es lo aceptable, y qué lo inaceptable. 
El análisis del corpus construido hasta el momento sobre los procesos de estigmatización, nos conduce a plantearnos nuevos y sugerentes interrogantes: ¿el sujeto siempre asume la etiqueta que se le asigna? Su asunción, ¿comporta indefectiblemente el comienzo de una carrera delictiva-desviada ${ }^{14}$ ¿Generan resistencias los sujetos al intento de atribución de una identidad deteriorada? Y si es así, ¿de qué manera? ¿Con qué tácticas? Las consideraciones de de Certeau (2007) serán nuestro hilo de Ariadna en la construcción de las respuestas a las incógnitas planteadas.

\section{I.a.3. Las taxonomías de la desviación como dispositivos coadyuvantes a la construcción del orden social}

Emile Durkheim (2006 [1895]) fue uno de los primeros teóricos en abordar las funciones sociales de la desviación. Para este sociólogo, la desviación contribuye a consolidar los valores y las normas culturales; deviene parte indispensable en el proceso de creación y mantenimiento del consenso sobre las mismas. El fenómeno de la desviación resulta funcional en dos sentidos: primero, porque provoca y estimula la reacción social, estabilizando y manteniendo vivo el sentimiento colectivo en el que se basa (la conformidad de las normas) y, en segundo lugar, porque el hecho de que la autoridad pública descargue su función reguladora sobre el fenómeno de la desviación proporciona pautas sociales para poder integrar elementos disfuncionales o de cambio social, coadyuvando así al fomento de la unidad social. La respuesta unitaria frente a las acciones de desviación fortalece el lazo social y contribuye a definir los límites morales.

Durkheim criticó la representación de la desviación como un fenómeno patológico argumentando que éste se da en toda sociedad. Está ligado a las condiciones y a la fisiología de toda vida colectiva como parte integrante de una sociedad "sana". En última instancia, el sujeto desviado no es un ser radicalmente antisocial, un

\footnotetext{
${ }^{14}$ Este interrogante no puede ser abordado etnográficamente ya que la institución estudiada no realiza un seguimiento de los chicos después de concluir la MPA.
} 
cuerpo extraño introducido en el seno de la sociedad, más bien ocupa el lugar de agente regulador de la vida colectiva que permite dotar a la estructura social, mediante una adecuada reacción reguladora, de elementos funcionales para la integración y cohesión del sistema.

Medio siglo más tarde, los teóricos del etiquetaje introdujeron un cambio de paradigma en el estudio de la desviación que supuso un viraje fundamental de la perspectiva de análisis: de estudiar el control social como respuesta a la desviación, se pasó a analizar la desviación como respuesta al control social. El nuevo objeto de estudio ya no sería el desviado y las causas de su comportamiento (paradigma etiológico), sino los órganos de control social ${ }^{15}$ y sus múltiples funciones de vigilancia de la desviación (paradigma de la reacción social). Este enfoque, como adelantamos en el apartado anterior, considera que es imposible comprender la desviación si no se estudia la acción de las instancias de control que la definen, comenzando por sus normas abstractas, hasta llegar a la acción de las instancias oficiales.

El labelling approach considera que la desviación hace referencia a comportamientos definidos como tales. Son comportamientos sociales como los demás, sólo que se definen como delito, enfermedad mental, etc. Tal y como indica Becker (op.cit.:19), el desviado es aquél a quien se le ha aplicado con éxito la etiqueta. No llega a alcanzar el estatus de desviado aquel que habiendo tenido el mismo comportamiento no ha sido alcanzado por la acción de las instancias de control. Así, la reacción social define un determinado acto como desviado, siendo la desviación una construcción social, no un hecho social, y el desviado aquel a quien se le ha atribuido esa marca anormalizante. No es el acto en sí mismo lo desviado, sino el significado que se le confiere, esto es, su interpretación. Para que un comportamiento desviado sea percibido como tal, resulta necesario observar la reacción social frente al mismo; la simple desviación objetiva respecto a un modelo o una norma no es suficiente, debe

\footnotetext{
${ }^{15}$ Sistema policial, judicial, psiquiátrico, médico, carcelario, asistencial, etc.
} 
de generar reacciones que perturben la percepción habitual y suscite indignación, embarazo, miedo, sentimiento de culpa, conmiseración, etc. ${ }^{16}$

Llegado a este punto del recorrido, estamos en condiciones de plantear una de las tesis principales que orienta esta investigación. A saber: todo orden se constituye a partir de una exclusión. (Tizio, 1997:93) Para darle un lugar de existencia a ese otro segregado es necesario clasificarlo previamente ${ }^{17}$, esto es, generar taxonomías que definan y ubiquen un lado oscuro del cual mantenerse alejado, y que, en ese alejarse, la sociedad pueda estructurarse y pensarse a sí misma como compacta y cohesionada. El imaginario social sitúa la existencia amenazante de los otros diferentes en los márgenes, en el exterior del grupo... en contra del orden de la comunidad. La construcción de la desviación/anomalía social es reflejo de los miedos que la sociedad experimenta. Atiende, como sostiene Lluis Mallart con relación a la enfermedad (citado en Gallén, op.cit.:56), a un dispositivo conceptual que permite explicar las diferentes formas de desorden que pueden desestabilizar una sociedad, o dicho de otro modo, un medio que permite pensar la sociedad, organizarla y re-estructurarla. El desviado garantiza la separación entre lo normal y anormal, lo ordenado y lo desordenado, lo puro y lo impuro, al marcar la distancia necesaria entre los dos dominios: un orden estructurado y armónico vs. un desorden informe y anárquico. Esta construcción del otro responde a operaciones lógicas, que como sostiene Lévi-Strauss (1982), se construyen

\footnotetext{
${ }^{16}$ No son pocos los criminólogos que han abordado el delito desde esta perspectiva. Dennis Chapman plantó en su obra "Sociology and the stereotype of the criminal" (1968) que el concepto criminal es una construcción social que forma parte del engranaje de la política del control social. Para Sack (citado en Baratta, op.cit.:108) la criminalidad, como realidad social, no es una entidad preconstituida respecto a la actividad de los jueces, sino una cualidad atribuida por estos últimos a ciertos individuos. El autor considera como juicios arbitrarios aquellos mediante los cuales atribuye un hecho punible a una persona (los cuales producen la cualidad criminal en el sujeto) con consecuencias juridicas (responsabilidad penal) y sociales (estigmatización, cambio de status, de identidad social, etc.). Desde la sociología del conflicto, Turk (1969) sostuvo la idea de que la criminalidad es un estatus social atribuido mediante el ejercicio del poder de definición. La criminalidad no es una conducta de un sujeto solo frente al Estado, sino el resultado de conflicto entre grupos. Atribuye al modo de operar de la policía el rol principal dentro de los mecanismos que llevan a la distribución de estatus de criminal y a su concentración en determinados grupos sociales en desventaja.

${ }^{17}$ Y la clasificación supone el acto de nombrar. (Leach, 1985)
} 
siempre a partir de oposiciones e incompatibilidades: incluido/excluido, normal/anormal, adaptado/inadaptado, orden/desorden...

La teoría psicoanalítica de la sociedad punitiva arroja luz a estas consideraciones. Sostiene que la reacción penal al comportamiento delictivo no tiene la función de eliminar o circunscribir la criminalidad, sino que corresponde a mecanismos psíquicos ante los cuales la desviación criminalizada aparece como necesaria e ineliminable para la sociedad. (Baratta, op.cit.:45) Los sujetos proyectan sus propias tendencias asociales, más o menos inconscientes, en la figura del delincuente. Edwar Naegeli (citado en Baratta, op.cit.:52) lo plantea en los siguientes términos: "En todo hombre hay una tendencia a transferir esta sombra [lo negativo de todo ser humano] a una tercera persona objeto de proyección, es decir, a desplazarla al exterior y con ello a concebirla como algo externo, que pertenece a un tercero. En lugar de dirigirse hacia sí mismo, se insulta y se castiga el objeto de esa transferencia, al chivo expiatorio, para el cual es sobre todo característico el hecho de que se halle en condición inerme".

Gallén (op.cit.: 88) destaca la importancia del papel paradójicamente central de los "excluidos" en todas las culturas: son fuente de desorden y contaminación, al mismo tiempo que son la sustancia generadora por excelencia a partir de la cual se hace y rehace la vida social. El etiquetado como "anormal", continúa la autora (op.cit.: 89), permite al orden social pensarse a sí mismo -con sus incongruencias y desordenes-, como el resultado contingente de una presencia monstruosa a la que es necesario vigilar. Operación que, como apunta Reguillo (2005:408), "aligera nuestras culpas y mitiga nuestros miedos". En su abordaje a los procesos de exclusión en la Edad Media (asombrosamente análogos a los contemporáneos), le Goff (2008:179) compendia de forma magistral las bases ideológicas de la exclusión. Merece ser citado en extenso: "en una sociedad [la medieval] acosada por el miedo a la contaminación ideológica, pero vacilante en cuanto a excluir a quienes puedan tal vez contribuir, contradictoriamente, a la salvación de los puros, lo que prevalece respecto de los marginados es una 
actitud ambigua. La cristiandad medieval parece desterrarlos y admirarlos a la vez; les tiene miedo en una mezcla de atracción y de espanto. Los mantiene a distancia, pero fija esa distancia de manera tal que los marginados estén al alcance. (...) La sociedad medieval tiene necesidad de esos parias apartados porque, si bien son peligrosos, son visibles, porque en virtud de los cuidados que les prodiga se asegura tranquilidad de conciencia y, más aún, porque proyecta y fija en ellos mágicamente todos los males que aleja de si".

La dicotomía normal-anormal garantiza la estricta separación de los contaminantes en una esfera segregada (pero al alcance) que delimita los incluidos de los excluidos. De esta manera, podemos entender la categoría discursiva "desviación", y su modalidad contemporánea, la "exclusión social", como herramientas imprescindibles en la construcción de un orden simbólico que sitúa a los individuos apresados en ellas como los expiadores de la comunidad, aquellos que disipan miedos al pensarlos del otro lado de la frontera del orden y la normalidad. Y es que la existencia del excluido, ser anómalo, confirma la situación de inclusión de incluido, el cual podrá respirar tranquilo sabiéndose dentro de los parámetros de la normalidad, alejado del desorden y el desconcierto. Las palabras de Gallén (op.cit.: 92) son reveladoras: "Todas las prevenciones, los cuidados, los riesgos que implica situarse en la frontera advierten no del riesgo que haya fronteras, sino del pavor descomunal que provoca imaginar que no las hubiera".

Además de procurar la separación entre normales y anormales, el poder de las taxonomías de la desviación -y su correlato de estigmatización- coadyuva a la consolidación del orden social al operar como dispositivos pedagógicos. Gallén (op.cit.) y Juliano (2002) se han referido a esta dimensión instructiva -la primera autora en relación al estudió de personas clasificadas como borderline, y la segunda, centrándose en la figura de la trabajador sexual-. Estas taxonomías operan como dispositivos pedagógicos que instruyen y aleccionan sobre el orden social, recordando en todo momento la existencia de las fronteras que separan lo "aceptable" de lo "inaceptable", y el precio que se paga por transgredirlas. El 
estigma "puta" deviene paradigmático en este sentido, pues advierte al resto de mujeres de los peligros que asedian a aquellas que osen traspasar el límite de lo moralmente correcto y permitido: el repudio y la vergüenza.

El riguroso análisis etnográfico que realiza Douglas (1978) sobre la brujería en África Central deviene ilustrativo al hilo de nuestras reflexiones. La brujería se presenta como dispositivo que contribuye al mantenimiento del orden social a partir de sus efectos de refuerzo moral y normativo en el comportamiento. La autora sostiene que los sistemas sociales tienen diversas interpretaciones del mal, y que todas ellas están encaminadas a reforzar los mecanismos de control sobre la población. Determinados valores morales se mantienen y ciertas reglas sociales se definen, gracias a las creencias en el contacto peligroso, como cuando la mirada de una persona que ha cometido adulterio se considera capaz de atraer la enfermedad sobre sus vecinos o sobre sus hijos. (Douglas, 1991a:XXXI)

Podemos encontrar en nuestras sociedades la misma operación lógica que en las sociedades africanas estudiadas por Douglas. Las comunidades analizadas por esta autora se sienten en el seno de un universo hostil donde existen fuerzas maléficas que las amenazan; los siniestros poderes son controlados por otros seres humanos: el brujo, un personaje perverso y malicioso. De esta manera, a su figura -una más del elenco de taxonomías de la desviación- y a los poderes ocultos que controla, le son atribuidas enfermedades, accidentes y demás infortunios. Nos topamos con la misma premisa: la idea del mal exterior (encarnada en la figura del desviado) y el bien interior (asentada en seno de la comunidad).

Douglas apunta dos pautas principales en la acusación de brujería (1991b:53-55) en las que podemos observar su funcionalidad, ese hacer y rehacer continuo del orden social y sus disposiciones estratificadoras. Cuando el brujo es una persona foránea a la comunidad, la función de la acusación consiste en reafirmar la frontera y la solidaridad intragrupal. Cuando el brujo es un "enemigo interior", la función de la acusación es volver a definir los límites, distribuir su jerarquía o 
dividir a la comunidad. Pero las acusaciones de brujería, como las de desviado, no sólo sirven para expulsar de la comunidad a un miembro "incómodo" o no deseado, es también un instrumento de conformidad que refuerza el sistema social moral y los códigos sociales. (Douglas, 1991a) La brujería deviene dispositivo pedagógico de control que advierte de manera subliminal sobre los riesgos que comporta desviarse del código normativo establecido, pues se corre el riesgo de ser tachado de brujo. Se trata de una poderosa herramienta de control: permite estigmatizar a aquellos individuos considerados desviados o disidentes responsabilizándolos de cualquier desgracia acontecida.

Remontándonos todavía más lejos en la historia, encontramos en la caza de brujas llevada a cabo entre los siglos XIII y XVIII otro de los propósitos cometidos de este tipo acusación. Además de un intento de acabar con la autonomía de mujeres paganas que actuaban al margen del cristianismo, González Echevarría (1984:14) añade que estas persecuciones fueron también un mecanismo para distraer al pueblo de las causas reales de sus males.

El tupido inventario de taxonomías estigmatizantes que nos remite al "Corazón de las tinieblas" de toda sociedad, da cuenta de poderosos mecanismos de control, estratificación y contención social... pero lo que es aun más estremecedor, a la vieja costumbre humana de ver el infierno en cuerpo ajeno: un intento de desresponsabilización de nuestras propias miserias interiores en la búsqueda de un otro que expíe nuestros pecados: bruja, puta, maricón, yonki, menor infractor, excluido social... Por fortuna, siempre nos quedarán los brujos dinka que, en lugar de enfatizar la hostilidad hacia los demás, nos recuerdan los peligros que hay en nuestro interior.

\section{I.a.4. Producción institucional de los sujetos desviados}

La confección del fenómeno de la desviación se edifica en torno a dos procedimientos: la producción del sujeto desviado, y su posterior publicitación. 
Retomando a Becker (op.cit.: 13), podemos decir que no es que existan per se y a priori sujetos cuyas conductas sean desviadas, sino que es en base a la creación e imposición social previa de un universo de reglas, que aquel de quien se cree que las ha quebrantado podrá ser ubicado como un "desviado". Todos los grupos sociales crean reglas y, en ciertos momentos y en determinadas circunstancias, intentan imponerlas. Las reglas sociales definen ciertas situaciones y los tipos de comportamiento apropiados para las mismas, prescribiendo algunas actuaciones como "correctas" y sancionando otras como "incorrectas". O dicho de otro modo, los grupos sociales con poder crean la desviación al hacer las reglas cuya infracción constituye la desviación, y al aplicar dichas reglas a ciertas personas en particular y clasificarlas de marginales. No se clasifica la desviación porque haya diferentes tipos, sino que es porque la clasificamos que podemos descubrirla. Recordemos las palabras de Delgado (op.cit:200): no es la diferencia la que suscita la diferenciación, sino la diferenciación la que crea y reifica la diferencia. La desviación no es una cualidad del acto cometido por la persona, sino una consecuencia de la aplicación que los otros hacen de las reglas y las sanciones para un "ofensor". El desviado es una persona a quien se ha podido aplicar con éxito dicha calificación; la conducta desviada es la conducta así llamada por la gente. (Becker, op.cit.:19)

En el proceso de desviación los infractores deben ser descubiertos, identificados, capturados, condenados por "anómalos", y estigmatizados por su inconformismo. Así, resulta necesaria una publicitación de la presunta desviación para que ésta genere las condiciones sociales asignadas para cada caso (menosprecio, encierro, eliminación física...). Esta consideración nos conduce directamente a la existencia necesaria de aparatos institucionales (creados por los grupos de poder) que, por un lado regulen y gestionen la desviación, y que por otro, confieran el estatuto de "desviado" a determinados individuos y grupos sociales, esto es, entidades que produzcan los sujetos desviados. Las instituciones de gestión del resto social han existido desde antiguo. Lugares que van desde la stultifera navis, pasando por manicomios, asilos, cárceles y entidades caritativas, hasta llegar a 
las manifestaciones más contemporáneas como los Servicios Sociales, los dispositivos de prevención social, o los CIE (Centro de Internamiento para Extranjeros) de la Unión Europea. Detengámonos en estas dos dimensiones apuntadas: producción y publicitación del sujeto desviado.

En primer lugar podemos convenir que las tareas de regulación y gestión institucional de la desviación insinúan el interés de los grupos de poder por mantener un determinado orden social. Aquellos que perturban el orden social, los "anormales", fuente de todo tipo de incertidumbres e inestabilidades, deben de ser ubicados en lugares que los separen de los normales a través de inquebrantables fronteras (físicas y/o simbólicas). Clasificar en grupos diferenciados ( $y$ supuestamente homogéneos) a los disidentes de la normalidad permite controlarlos al inscribirlos en instituciones ad hoc concebidas para cada una de las desviaciones ideadas (los "primodelincuentes" en entidades de "prevención del delito", "enfermos mentales" en el manicomio, los "drogodependientes" en los centros de rehabilitación, las "madres solteras" en las casas cunas, y así, un inconmensurable etcétera).

En un momento histórico marcado por fuertes asimetrías sociales, y vigorosos procesos de homogenización y segregación, los ideales adaptativos, y con ellos los binomios adaptado-inadaptado, incluido-excluido, normal-anormal, etc., cobran un fuerte protagonismo. La producción actual del resto social deviene desmesurada y arrolladora. Es por ello que los dispositivos contemporáneos encargados de su gestión -desde sus modalidades represivas (cárceles, reformatorios, manicomios, etc.) hasta los asistenciales (centros de reinserción, comunidades reeducativas, asistencia social, etc.)- devienen poderosos y necesarios instrumentos de control y contención del conflicto y el desorden. En este sentido, la obra de de Stanley Cohen (1988) sobre la sociedad moderna como sociedad disciplinaria ("Visiones de control social") realiza un interesante examen sobre las transformaciones producidas en la historia reciente de las sociedades occidentales, que influyeron decisivamente en la definición, organización y perfeccionamiento de los sistemas de control social de la desviación. Si bien el 
marco del presente trabajo no permite que nos detengamos en ellas, es útil precisar de manera sintética los principales cambios a los que dieron lugar dichas transformaciones, cuestión que sin duda nos permite delinear con más precisión los relieves del escenario que tratamos de dibujar. El autor apunta el incremento progresivo de la involucración del Estado en el control de la desviación; aumento de clasificaciones y diferenciaciones de los desviados con la consiguiente creación de monopolios especializados de profesionales ocupados de cada tipo de desviado; incremento de la segregación de los desviados en instituciones cerradas; y por último, la sustitución y extensión del cuerpo por la mente como objeto del control social.

En segundo lugar, con respecto a la publicitación de los sujetos desviados, nos remitimos a las palabras de Tizio (op.cit.: 98-99), quien sostiene que la "desviación" para existir debe ser nombrada; no se dice en primera persona, es un tercero, Otro social, el que hace el juicio. De este modo, la desviación social no existe fuera de los aparatos, instituciones y profesionales que la designan y regulan. Recordemos a de Leo: las instituciones penales no son respuesta al fenómeno de la criminalidad sino que tienen una función productiva y constitutiva del fenómeno mismo.

Karsz (2004:133-134) articula los dos puntos anteriores al señalar que -y con esto nos adentramos en la idea del "excluido social" como personaje desviado contemporáneo- que no cualquier persona puede acceder y figurar en dicha categoría. Hay que tener problemas diversos y, además, estar apresado en las mallas de cierta maquinaria de codificación de lo real. ${ }^{18}$ Para entrar a la categoría exclusión, individuos y grupos deben conocer ciertos itinerarios materiales relativamente típicos, y presentar cierto número de características determinadas en términos de empleo, escolaridad, vivienda, vida familiar, etc. La condición suficiente es realizar un itinerario inscrito en una serie de significaciones teóricas,

\footnotetext{
${ }^{18} \mathrm{El}$ autor se refiere a las redes institucionales de asistencia social.
} 
de clasificaciones administrativas, de intimidaciones institucionales, de asignaciones económicas y de tratamientos políticos.

\section{I.a.5. "Exclusión social" como categoría discursiva de la desviación contemporánea}

Hemos sostenido que cada sociedad, en cada momento histórico, ha encontrando las categorías necesarias para designar y clasificar a los sujetos que perturban el orden social, así como los aparatos institucionales destinados a su gestión. La categoría "exclusión social" ocupa un lugar privilegiado en el discurso de época para designar las nuevas formas de pobreza, al mismo tiempo que viene a condensar, en sus múltiples subcategorías, a individuos y grupos que inquietan y desordenan el paisaje social ("niño de la calle", "menor infractor", "inmigrante", "toxicómano"...). De esta manera, se nombra y se opera sobre aquellos sujetos que aparecen como fracasos normativos para las lógicas sociales.

Si el "excluido social" es el "desviado" contemporáneo, podemos ubicar otras formas históricas de nombrar la desviación social. Renouard (citado en Tizio, 1997:94-95) ubica cuatro momentos comprendidos entre 1830 y 1970, así como sus instituciones de gestión para cada uno de ellos. Debemos destacar de este recorrido la inmemorial vinculación, palmariamente vigente en nuestros días, que el poder político ha realizado entre sujetos desviados y pobreza, cuestión que nos permite imbricar ambos fenómenos discusivamente. Los grupos considerados desviados coinciden con los sectores socioeconómicamente más empobrecidos, que es donde los aparatos institucionales descargan su acción social (asistencia, caridad, programas de prevención, etc.). Se trata de una vieja ecuación: a mayor marginación social, mayor control institucional.

Las instituciones asistenciales y represivas operan como elementos que permiten regular y contener a las emergentes "clases peligrosas", consideración que nos permite anudar, como veíamos en Cohen (op.cit.), el trabajo social (de financiación gubernamental o privada) con cuestiones de orden público. 
1. De 1830 a 1880. La definición de "desviación" viene dada en términos de culpabilidad. El aparato de gestión es la administración penitenciaria, cuya finalidad es la neutralización/corrección del sujeto. La atención se focaliza en éste y su acto, y se opera a través del castigo. Es la llamada Escuela Clásica del Derecho Penal, adherida a las concepciones de Beccaria. La culpabilidad se centra en el sujeto.

Este modelo, contemporáneo a la burguesía en ascenso, privilegiaba dos valores: el trabajo y la libertad. De allí el intento, mediante la reclusión y la disciplina, de que el sujeto tomara esos valores. La finalidad correccional era un recurso a la disciplina en el marco de un modelo carcelario.

2. De 1880 a 1920. La definición está dada en términos de victimización. El aparato de gestión está imbuido de las ideas del movimiento filantrópico, y la finalidad es la moralización. Al considerar al sujeto como víctima se formula un programa tutelar que incluye las acciones educativas. El pasaje de la corrección a la moralización, entendida como salvación del sujeto y de la sociedad, pone la acción educativa en primer plano. La problemática del sujeto es utilizada para hablar de desviación familiar. Se pasa de la responsabilidad del sujeto a la responsabilidad familiar. Se desculpabiliza al sujeto y se culpabiliza la familia. La problemática del sujeto sería efecto de la mala educación por la ineptitud familiar o por la inmoralidad del medio. El alcoholismo, la prostitución, la falta de recursos devienen indicadores de la "debilidad moral" de la familia, pues la suposición de peligrosidad se focaliza en ésta. De este modo se pasa de la dimensión retributiva al cambio moral.

3. De 1920 a 1970. La definición de desviación está dada en términos de inadaptación. El aparato de gestión es la psiquiatría y la justicia para niños, cuya finalidad es la integración socioprofesional de los sujetos "inadaptados". El pasaje de la moralización al de adaptación marca una nueva forma de considerar la desviación. Éstos aparecen como la antítesis de la adaptación social, y los profesionales del campo social trabajan para su reinserción. 
4. Desde 1970. El discurso pone en primer plano las carencias sociales de los sujetos. El aparato de gestión son los servicios sociales, cuya finalidad es integración social de la exclusión. El trabajo social (materializado en el vasto entramado de instituciones asistenciales) se propone como elemento regulador de la crisis social, que aparece como una actividad que toma a su cargo los problemas del "mal" funcionamiento social.

El recorrido de Renouard termina en la década de los setenta donde la desviación social viene definida a través de la categoria "inadaptación". Éste fue el significante en uso hasta principios de la década de los noventa, cuando la Comisión Europea privilegió la utilización de la categoría "excluido social" en el debate sobre la desigualdad y las políticas sociales ${ }^{19}$, logrando así un amplio consenso de uso en el discurso político, mediático, sociológico, y de los profesionales del campo social a ambos lados del Atlántico.

Sin embargo, más allá del cambio de significante, podemos convenir que el modo de operar continúa siendo el mismo. Las instituciones contemporáneas de gestión del resto social procuran, a través de acciones educativas, la "reinserción" o "readaptación" de aquellos sujetos que no tienen una integración normalizada a la esfera pública. La estructuras simbólicas que subyacen en estos dispositivos tejen una urdimbre de categorías que clasifican y diferencian, por ejemplo, a los "buenos pobres" de los "malos pobres", o que distinguen y etiquetan a sujetos inadaptados, re-educables y re-insertables, etc. Categorías que lejos de ser objetivas, operan como marcas que coadyuvan a la estigmatización y abyección de sus portadores. Se trata de atributos inferiorizadores aplicados con el propósito de constatar que el "excluido" es "anómalo" y "peligroso", y que por tanto, debe ser no sólo custodiado y controlado, sino también sometido a nuevos entrenamientos y marcajes que, como apunta Balandier (1994:65), permitan deconstruir y reconstruir su personalidad.

\footnotetext{
${ }^{19}$ Algunas interpretaciones sostienen que la Comisión favoreció el uso de una expresión distinta a la de pobreza ante la incomodidad de los Estados miembros por asumir la persistencia, y en algunos casos, el aumento, del número de pobres en sus países. (Moreno, 2000:58) No olvidemos que existen 52 millones de personas pobres en la Unión Europea. Para la nueva retorica oficial, el uso de la denominación "exclusión" posee un carácter menos "incorrecto" políticamente.
} 
En esta nueva modalidad discursiva de nombrar la desviación persisten dos fenómenos. Por un lado, se mantiene la codificación de la desviación en términos morales; las instituciones que regulan la exclusión social también pretenden la moralización del sujeto, al que supone una suerte de desviación moral. Por otro lado, perdura la antigua equiparación entre desviación y pobreza. La exclusión social, como cualquier otra modalidad de desviación, se define con relación a los ideales de época. Los preceptos contemporáneos están atravesados por la lógica neoliberal, de tal manera que los individuos que no alcancen los crecientes estándares de productividad y consumo quedarán del lado de la anomalía y la irregularidad. Así, el "excluido social", como sus modalidades predecesoras de desviación, presentan un desajuste entre el individuo y la sociedad en términos morales y de productividad económica.

La "exclusión social" nombra la desviación de forma edulcorada y dentro del orden de lo políticamente correcto. Sin embargo, veremos que, pese a que el discurso y los nuevos dispositivos de gestión de la exclusión se han disfrazado de mayor civilidad (ONG, Servicios Sociales, entidades para la prevención social...), los mecanismos de clasificación y estigmatización no han cambiado lo más mínimo. El poder estigmatizante de la categoria "excluido social" continúa operando con la misma fuerza implacable que sus predecesoras ("inadaptado", "vago", "maleante"). Aunque con apelativos diferentes, las categorías nos remiten a un mismo orden simbólico, a un mismo lugar: lo peligroso y contaminante, lo impuro y desordenado. Nuevos discursos que encubren viejas prácticas.

Concluimos estas líneas apuntando una idea final. La eficacia social de los discursos consiste en que las definiciones tienen su eficiencia propia porque el significante, aquel utilizado para clasificar, crea realidades. Por ello, no se trata de buscar la verdad última sobre la "exclusión social" sino de analizar el aparato conceptual que se utiliza para nombrarla. Se trata, en última instancia, de abrir un interrogante profundo que marque los caminos de una investigación necesaria que 
nos ayuden a desentrañar las operaciones e intenciones que subyacen en los mecanismos de clasificación de esos otros estigmatizados.

\section{I.b. UNIVERSO CONCENTRACIONARIO Y "EXCLUSIÓN SOCIAL": LA GESTIÓN DIFERENCIAL DE CIERTAS POBLACIONES}

Presentamos en esta segunda parte del capítulo otro de los abordajes posibles a la inmemorial modalidad de exclusión que tratamos de desentrañar: la otorgación de un estatuto especial a determinados sectores sociales que les permite coexistir en la comunidad, pero que, al mismo tiempo, les priva de ciertos derechos, y de la participación en determinadas acciones sociales. Esta modalidad nos remite a las viejas prácticas de separación y alejamiento que en la actualidad se metamorfosean en la asignación de nuevas y edulcoradas categorías. (Lo que no cambia es la elección de los sectores poblacionales a los que se les inflige la marca). Hoy, la "exclusión social" es la etiqueta que otorga ese estatuto devaluado, y que permite apresar, clasificar y operar sobre aquellos que no tienen una incorporación "normalizada" en la sociedad, los perturbadores del orden social, el resto.

Lo que nos interesa aquí es, por un lado, elucidar cómo la asignación de la categoría de época "exclusión social" restringe el acceso a ciertos derechos y despoja de valor político a sus portadores, y por otro, desentrañar la producción de la exclusión como un fenómeno que acontece en el interior del propio sistema, no en sus márgenes. Las nociones de universo concetracionario, nuda vida (Agamben, 2006) y biopolítica (Foucault, 1994) nos permiten realizar un acercamiento interesante en el sentido señalado. Es necesario aclarar en este punto que el análisis que presentamos a continuación tiene como propósito trazar algunas de las coordenadas medulares de una topografía extensa: los procesos contemporáneos de exclusión en su sentido amplio. Si bien las categorías agambeanas no son estrictamente válidas para referirnos a los "menores 
infractores" que cumplen una pena no privativa de la libertad ${ }^{20}$, son aparejos meritorios e imprescindibles en el desentrañamiento del tratamiento y los engranajes que conforman la gestión diferencial de ciertas poblaciones.

\section{I.b.1. Introducción a las categorías homo sacer y nuda vida}

Desde el comienzo, la modernidad, acompañada de su progreso económico, arrojó enormes cantidades de lo que Bauman ha denominado sobrante humano. (2005:161) Todo modelo de desarrollo es selectivo y exige el recorte, la poda, la segregación, la separación o la extirpación de aquellas partes de la materia prima humana que demuestren ser ineptas para ese modelo. Dichas partes emergen como sobras al final de la cadena de producción del orden social, diferenciándose de los productos deseables y útiles. El actual modelo de desarrollo neoliberal exige de la invalidación y la eventual aniquilación de ciertos modos de vida y de subsistencia del ser humano, ya que no pueden ni podrían alcanzar los crecientes estándares de productividad y rentabilidad. Se trata, como sostiene Wallerstain (2006:41), de mecanismos estructurales mediante los cuales quienes no actúan bajo la premisa de la acumulación incesante de capital son eliminados eventualmente (o para siempre, añadiríamos) de la escena social. Por primera vez en la historia, nos dice Forrester (1997), sectores cada vez mayores de población se tornan innecesarios, prescindibles.

Lo particular de este momento histórico no es que exista desigualdad, ya que siempre la ha habido, sino que hoy esa exclusión alcanza dimensiones nunca antes vistas. Los "desechables", los "imprescindibles", los "superfluos" crecen día a día de forma incontenible. Las zones d'attente de algunos aeropuertos

\footnotetext{
${ }^{20}$ El "tratamiento en externación" de las MPA no cuenta con el grado de violencia y barbarie de universos concentracionarios como, por ejemplo, los presidios contemporáneos. Por otro lado, y como veremos en el próximo capítulo, los jóvenes de la institución estudiada no son enteramente nuda vida. Aunque carecen de valor político y del acceso a ciertos derechos, no están del todo inermes en el espacio de excepción.
} 
internacionales ${ }^{21}$, la cárcel de Guantánamo, los Centros de Detención de Extranjeros $(\mathrm{CIE})$, las periferias de algunas ciudades, cárceles, manicomios, Servicios Sociales... son nuestros estados de excepción contemporáneos, una estructura política fundamental que, tal y como sostiene Agamben (op.cit.), ocupa cada vez más un espacio protagónico en nuestro tiempo, amenazándonos con convertirse en regla. En la lógica de la excepción, la ley se aplica desaplicándose. Se trata de espacios donde el orden jurídico normal queda suspendido, y donde si se comenten, o no atrocidades no dependen del derecho, sino del funcionario, policía, carcelero o trabajador social de turno.

Para este autor el campo de concentración es el espacio que se abre cuando el estado de excepción empieza a convertirse en regla. Es precisamente su nacimiento lo que marca de manera decisiva el espacio político de la modernidad. "La creciente desconexión entre el nacimiento (la nuda vida) y el Estado nación es el hecho nuevo de la política de nuestro tiempo, y lo que llamamos campo de concentración es precisamente tal separación". (op.cit.:223)

Arendt (2004) se refirió en su obra "Los orígenes del totalitarismo", a los campos de concentración como la manifestación más sangrante de la dominación totalitaria, cuyo triste corolario fue el "todo es posible"; la paradójica experiencia humana de la deshumanización. Lo sustancial de la obra de Agamben reside precisamente en la idea de que ese "todo es posible", ni se acota a los campos de concentración nazis, ni pertenece únicamente al pasado. Por el contrario, se ha extrapolado y extendido a otras esferas de la vida social contemporánea, convirtiéndolas en estados permanentes de excepción.

Se imponen algunas precisiones sobre las categorias nuda vida y homo sacer (Agamben, op.cit.) antes de continuar nuestro recorrido. La primera de ellas alude a la vida a quien cualquiera puede dar muerte, pero que es a la vez insacrificable:

\footnotetext{
${ }^{21}$ En la zone d'attente francesas los extranjeros pueden ser retenidos durante cuatro días antes de la intervención de la autoridad judicial.
} 
el homo sacer. Se trata de una figura del derecho romano arcaico, en que la vida humana se incluye en el orden jurídico únicamente bajo la forma de su exclusión, esto es, de la posibilidad absoluta de que cualquiera lo mate. Podríamos referirnos, en un uso biopolítico del término, a aquellos que son "matables", "desechables", "inservibles"; los sustraídos radicalmente de la comunidad cuya muerte no entraña en la práctica ninguna consecuencia jurídica. En la modernidad, apunta Foucault (op.cit.), la biopolítica inscribe la vida en el centro de la política estatal. Se produce así una transformación del enunciado básico de la soberanía jurídica: de hacer morir y dejar vivir, recalamos en el hacer vivir y dejar morir. De esta manera todos los ciudadanos se presentan virtualmente como homo sacer. "La sacralidad de la vida, que hoy se pretende hacer valer frente al poder soberano como un derecho humano fundamental en todos los sentidos, expresa, por el contrario, en su propio origen la sujeción de la vida a un poder de muerte, su irreparable exposición en la relación de abandono". (Agamben, op.cit.:109) Nos topamos aquí con el poder soberano: cuya estructura original está constituida en la excepción y, por ende, en la capacidad de producir nuda vida, aquella desposeída de todo valor político.

Para Agamben, las parejas categoriales fundamentales de la política occidental son nuda vida-existencia política, zoé-bíos, y exclusión-inclusión. Esto es, la distinción entre vida natural y vida política, entre el hombre como simple ser viviente y el hombre como sujeto político. Como en Foucault (op.cit.), la introducción de la zoé en la esfera de la polis constituye el acontecimiento decisivo de la modernidad (primer paradigma del espacio político de Occidente). Sin embargo, Agamben completa la tesis foucaultiana añadiendo un proceso paralelo en el que, al mismo tiempo que la excepción se convierte en regla, el espacio de la nuda vida -situado originalmente al margen del orden jurídico- va coincidiendo de manera progresiva con el espacio político, de forma que zoé y bíos, exclusión e inclusión se tornan irreductiblemente indiferenciables. En el nacimiento de la democracia moderna, la nuda vida se convierte en el nuevo cuerpo político de la humanidad. 
La exclusión como norma es otra de las tesis de Agamben que permiten el desarrollo de nuestro análisis. El autor sostiene que la excepción es una especie de exclusión, y que ésta tiende a convertirse en regla. Lo que caracteriza a la excepción es que lo excluido no queda absolutamente privado de conexión con la norma; por el contrario, se mantiene en relación con ella en forma de suspensión. La excepción no se sustrae de la regla, "si no que es la regla la que, suspendiéndose, da lugar a la excepción y, sólo de este modo, se constituye como regla, manteniéndose con relación a aquella". (op.cit.:30) Reiteramos el punto clave del universo concentracionario: la norma se aplica en la excepción desaplicándose, retirándose de ella.

\section{I.b.2. Otorgar un estatuto especial: la categoría "exclusión social"}

Apuntamos en la primera parte del presente capítulo que cada momento histórico ha contado con modalidades particulares de definir y operar sobre el sobrante humano. Robert Castel (2004a:65-66) apunta en su texto "El encuadre de la exclusión", tres modalidades históricas de exclusión: la realizada mediante una sustracción completa de las comunidad (deportación, destierro, matanza...); la construcción de espacios cerrados en el seno de la comunidad, pero separados de ésta (manicomios, prisiones, guetos...); y por último, la asignación a ciertas poblaciones de un estatuto especial que les permita coexistir en la comunidad, pero que las priva de ciertos derechos, y de la participación en determinadas actividades sociales. Nuestro objeto de investigación se inscribe en la geografía de esta tercera modalidad, de donde la inscripción de ciertos sectores poblacionales en la categoría de época "exclusión social"22 deviene una de sus manifestaciones contemporáneas.

22 En su multiplicidad de subcategorías: "menores infractores", "jóvenes antisociales", "drogadictos"... 
El mecanismo es simple: se establecen categorías diferenciales de individuos y grupos sociales que, posteriormente, serán gestionados a través de procesos de distribución y "tratamiento" en circuitos ad hoc para cada una de los marcajes elaborados. Se trata de lo que Castel (1984) ha llamado gestión diferencial de (ciertas) poblaciones. Los dispositivos de intervención social directa gestionan el resto social, aquellos que, como veíamos anteriormente, no cuentan con una incorporación normalizada en la sociedad; sectores poblacionales que no alcanzan los crecientes estándares de productividad y rentabilidad económica, quedando excluidos de la inscripción en el sistema de derechos y de la participación social que comporta el estatuto de ciudadanía.

Abordamos en párrafos precedentes la tesis de Douglas (1991b) por la que podíamos acceder a los límites simbólicos que separan los grupos, a través del análisis de las clasificaciones sociales (limpio/sucio, puro/contaminado...). Lo que "está fuera de lugar", lo corrompido e infecto, encubre una reflexión sobre las fronteras entre las categorías sociales. Por lo que las estructuras simbólicas que operan en la categoría "exclusión social" dan cuenta de la estructura social en la que se inscribe. Existe un límite simbólico que distingue lo sucio (el excluido, el desviado y contaminado), de lo limpio (el incluido, el normal y puro). Los primeros serán estigmatizados por su impureza, los segundos, quedarán "limpios" de todo signo infamante.

Este orden simbólico velado permite al discurso de época situar al "excluido social" fuera de la comunidad a la que pertenece. Se trata de sujetos que presuntamente carecen de vínculos sociales; están des-afiliados, y por tanto fuera de lo social. Sin embargo, para Agamben, la exclusión se produce en el interior de los dispositivos sociales. Se trata del estatuto paradójico del campo de concentración en cuanto a espacio de excepción: es lugar que se sitúa fuera del orden jurídico normal, pero que no por eso es simplemente un espacio exterior. (op.cit.:216) Los "excluidos sociales" forman siempre parte de la sociedad de la que se dice son expulsados. Están no fuera de la sociedad, sino fuera de ciertos circuitos, de ciertas prácticas. 
Son exiliados en el interior del sistema. Si, como sostiene Castel (2004b:63), la descolectivización es en sí misma una situación colectiva, podemos convenir que la pareja formada por "exclusión" y "social" se confronta mutuamente, encerrando contradicciones insostenibles.

Retomemos en este punto uno de los axiomas fundamentales de nuestra investigación: todo orden se construye a partir de una exclusión. (Tizio, op.cit.) Podemos pensar en los "excluidos" contemporáneos como los representantes de la nuda vida que la modernidad crea necesariamente en su interior, pero cuya presencia no consigue tolerar en modo alguno. Agamben sitúa aquí la fractura biopolítica fundamental: es lo que no puede ser incluido en el todo del que forma parte, y lo que no puede pertenecer al conjunto en el que está ya incluido siempre. (op.cit.:226)

La fractura resultante entre bíos y zoé que encierra la nuda vida, toma forma en la excepción, esto es, en algo que sólo es incluido por medio de una exclusión. La excepción es una exclusión inclusiva, que sirve para incluir lo que es expulsado. Los excluidos se incluyen en el sistema "excluyéndose", esto es, ocupando el lugar de "otro", del "diferente", del que queda "afuera". Al mismo tiempo, los incluidos necesitan de los excluidos para certificar su condición de "incorporado" en lo social.

El abordaje que Octavio Paz (1993) hace de los "Pachucos" (grupo social al que hoy el discurso de época categorizaría como excluido), ilustra de manera bellísima esta cuestión, al mismo tiempo que bosqueja algo de los jóvenes que poblaron el dédalo etnográfico de esta investigación. Los pachucos, señala Paz, se incluyen en la sociedad norteamericana excluyéndose. Son bandas de jóvenes, generalmente de origen mexicano, que viven en ciudades del sur de EEUU. Se singularizan por su vestimenta, conducta y lenguaje. Los pachucos son seres liminales: no reivindican la nacionalidad de sus antepasados, ni se identifican con la cultura norteamericana y la moralidad de su American way of life. A pesar de 
esta liminalidad flotante, Paz señala su ferviente voluntad de ser, una voluntad que no afirma nada concreto sino la decisión de no ser como las personas que les rodean. Los pachucos responden a la hostilidad de una sociedad que los rechaza reafirmando vivamente su identidad. Lejos de decantarse por la carrera de obstáculos de la adaptación a su entorno, afirman y subrayan sus diferencias. Con su conducta anárquica, nos dice el autor, señalan "no tanto la injusticia o la incapacidad de una sociedad que no ha logrado asimilarlos, como su voluntad personal de seguir siendo distintos". (op.cit.:17) Su conducta agresiva y provocadora es una exageración de los modelos contra los que pretende rebelarse. Subrayan con su indumentaria el deseo de separarse de la sociedad. Su puesta en escena, con su suerte de disfraces y artificios, los protege al mismo tiempo que los destaca, los oculta al mismo tiempo que los exhibe. Sabe que su dramaturgia irrita y exaspera a la sociedad. Es esta provocación la que les permite construir un lugar en la sociedad que hasta hace poco los ignoraba: victima, delincuente, etc. El pachuco se incluye excluyéndose. "Se lanza al exterior, pero no para fundirse con lo que lo rodea, sino para retarlo". (op.cit.:20) El pachuco afirma su exasperada voluntad de no-ser. Es un ser "peligroso". Su peligrosidad brota de su singularidad. Es un personaje híbrido, perturbador y fascinante... algo que debe ser suprimido.

Encontramos otro de los aspectos de la exclusión social como espacio de excepción en las restricciones de acceso al orden jurídico normal de los "excluidos" (más allá de que el discurso oficial los ubique como ciudadanos de pleno derecho). En el tiempo de la biopolítica el poder decide sobre el momento en que la vida deja de ser políticamente relevante: esta categoría, y los individuos que la encarnan, carecen de valor político. Ya a principios del siglo XX, Simmel (1971 [1908]) situó la pobreza como una ciudadanía de segunda clase. Los pobres son miembros de la sociedad, pero la ayuda que reciben del Estado (o de instituciones aparadas en él, como sería nuestro caso) no les es otorgada para asegurar su igualdad como ciudadanos, sino para preservar la fábrica social. Los pobres que reciben asistencia estatal son concebidos como objetos inertes sin 
derechos. La ayuda pública, continua Simmel, es una rama de la Administración en la cual las partes interesadas no tienen ninguna participación. Son sujetos subordinados, con derechos pasivos que se fundan en una relación de dependencia con la Administración. No son concebidos como sujetos de derecho, sino como individuos "defectuosos" al que los que hay que corregir o domesticar para que puedan adecuarse a estilos de vida "estandarizados"; o dicho de otro modo, a las formas que requiere el mercado laboral. Todo ello en nombre de la "reinserción", la "reeducación" o la "prevención". Atrapados en una red institucional que trata de recalificarlos moralmente, se los conmina a tener una individualidad moralmente sana. Volvemos, como se verá en el próximo capítulo, al higienismo decimonónico y su idea de "individuo moral".

Dos últimas consideraciones importantes a modo de cierre. En el proceso de antagonismo que conduce al reconocimiento de los derechos y de las libertades encontramos el cuerpo sagrado con su doble soberano, su vida insacrificable $y$, sin embargo, expuesta a que cualquiera se la quite. Con esta idea Agamben no trata de devaluar los logros y los esfuerzos de la democracia. Más bien trata de comprender por qué, "en el mismo momento mismo en que parecía haber vencido definitivamente a sus adversarios y haber llegado a su apogeo, se ha revelado de forma inesperada incapaz de salvar de una ruina sin precedentes a esa zoé a cuya liberación había dedicado todos sus esfuerzos". (op.cit.:20)

La tesis que postula una íntima vinculación entre democracia y totalitarismo deviene esencial para entender los procesos contemporáneos de exclusión. Es especialmente valiosa al permitirnos inferir que, hasta que no se resuelvan las contradicciones que implica que nuestra política sólo reconozca la vida como único valor, nazismo y fascismo, que habían hecho de la decisión sobre la nuda vida el criterio político supremo, seguirán siendo actuales, incluso en sus versiones más edulcoradas. Sólo una política que sea capaz de superar la escisión biopolítica fundamental de Occidente, podrá detener el creciente abismo entre incluidos y excluidos, privilegiados y desposeídos, ciudadanos y no 
ciudadanos, etc. Si no se vence esta separación, cualquier intento de fundar libertades políticas en los derechos del ciudadano estará condenado al fracaso.

En este sentido, resulta imprescindible pensar la acción de los dispositivos del campo social en relación con lo político; de lo contrario están abocadados a reproducir la exclusión en lugar de combatirla, y con ella a propagar el paradigma político del espacio de excepción que, estigmatizando e inferiorizado, priva a individuos y grupos sociales cada vez más amplios del valor político que, de forma inherente, posee toda vida humana por el simple hecho de existir. 


\section{CAPÍTULO II}

\section{TRAMAS DE SENTIDO Y JUEGOS TÁCTICOS EN EL TRÁNSITO INSTITUCIONAL (NO CARCELARIO) DE JÓVENES “DELINCUENTES”: DRAMATURGIAS, RESISTENCIAS Y SUBJETIVACIONES}

\section{II.a INSTITUCIONES DE "REINSERCIÓN" Y "PREVENCIÓN" SOCIAL: INVENTARIOS PARA LA ORTOPEDIA MORAL}

It is ironic that the obsessive solicitude of family, church, moralist, and administrators for child welfare served to deprive children of the freedoms that they

had previously shared with adults and to deny their capacity for initiative, responsibility, and autonomy. The "invention" of delinquency consolidated the inferior social status and dependency of lower-class youth.

ANTHONY M. PLATT

\section{II.a.1. Marcas contemporáneas del discurso neohigienista}

\section{Breves pinceladas históricas}

Las concepciones liberales del siglo XVIII y el cientificismo del XIX inauguraron una implacable cruzada contra el vicio, la depravación, y la inmundicia moral. La transparencia y el control fueron sus principales consignas; las clases obreras y populares, su objeto de intervención. EI siglo XIX ve nacer la justificación social y moral a todas las técnicas de señalamiento, clasificación e intervención dirigidas a los anormales, esa "gran familia indefinida y confusa", y el acomodo de una trama institucional que, en los límites de la medicina y la justicia, sirve simultáneamente como estructura de recepción para los desviados, y como instrumento para la 
defensa del nuevo orden social. ${ }^{23}$ (Foucault, 2000a) Sus concepciones, caballo de batalla de la prevención de los comportamientos considerados socialmente indeseables, se erigieron como baluarte de la lucha contra la miseria moral y material. Esta lógica supuso el deslizamiento de las premisas del discurso médico, al discurso social. (Núñez, 1990) Así, significantes como "prevención", "riesgo", "tratamiento", "intervención", etc. comenzaron a formar parte de la jerigonza cotidiana de las prácticas del campo social. Es útil precisar que la vinculación entre pobreza y "clases peligrosas" de volverá, a partir de entonces, inextricable, irrevocable...

Uno de los más insignes apóstoles del "buen gobierno" decimonónico fue Jeremy Bentham. Este pensador liberal sostenía que los marginales de su época requerían de la coacción pura, instrumento mucho más efectivo que cualquier llamado a la inteligencia -por cierto, inconstante y hasta inexistente- de los pobres. "Los despojos, la escoria de la humanidad", los adultos y los niños sin medios de sustento, los mendigos, las madres solteras, los aprendices rebeldes y otras gentes de su calaña, debian ser detenidos y llevados por la fuerza a hogares de trabajo forzado, administrados de forma privada donde "la escoria se transformaría en metal de buena ley". ${ }^{24}$ (Bentham citado en Bauman, 1999:137) Su propuesta moralizadora deseaba eliminar el peligro, iluminando con la mirada panóptica hasta el último rincón donde el vicio y la depravación acechaban. Asistimos a la aparición de diferentes instituciones de control, prevención y rectificación (y de las categorias de individuos a las que se dirigen), así como a toda una serie de mecanismos de vigilancia, distribución y gestión de las "nuevas clases peligrosas".

La pedagogía no fue ajena a los ideales de época de este poco afortunado episodio de la historia. Ésta será atravesada por un doble registro político: por un lado, como disciplina que aportará el diseño escolar a modo de dispositivo de

\footnotetext{
${ }^{23}$ Recordemos aquí que el higienismo constituyó un resorte imprescindible en la tecnificación y consolidación del Estado.

24 Propuso al mismo tiempo construir 500 hogares para 2000 de los pobres que representaban "una carga pesada" para la sociedad, manteniéndolos allí bajo la vigilancia constante y la autoridad de un alcalde.
} 
anulación de diferencias; y, por otro, como pedagogía especial, disciplina que aportará el diseño de los espacios de segregación de los anormales. (Núñez, op.cit:92) La pedagogía correccional -que cristaliza con el higienismo- tuvo como objeto de atención especializada a todos aquellos sujetos que encarnaban la discrepancia. En su dimensión asistencial, operó para el "enderezamiento" y la "reforma" de aquellos sectores que quedaban fuera de la norma. La acción educativa devino así una suerte de tecnología de la sujeción (Núñez, op.cit.:101) dirigida a lograr el control sobre el individuo y sus circunstancias. La vigilancia, el control y la moralidad de los sujetos fueron las orientaciones que, sostenidas en el tiempo, contribuyeron a edificar la educación social contemporánea y su tratamiento de la "exclusión social".

\section{Neohigienismo contemporáneo: estudio de caso}

En la actualidad, encontramos el viejo paradigma positivista, y su retórica higienista, reimplantados con fuerza en el campo de las ciencias sociales. Considerando que los discursos no se circunscriben solamente a los "decires", sino que están compuestos indisolublemente por las prácticas sociales y las representaciones que le van asociadas de forma estrecha (Foucault, 1970), vislumbramos un escenario inquietante para la praxis del trabajo social educativo. Hoy las nuevas tecnologias de control social aparecen travestidas de oratoria filantrópica y lenguaje políticamente correcto. Significantes como "reinserción", "prevención", "riesgo social", "re-educación"... dan cuenta de esa urdimbre de tácticas locuaces que configuran estrategias silenciosas (Foucault, 1980:95): el control y la contención social de los "excluidos".

El acercamiento etnográfico nos ha permitido desencriptar algunas de las marcas institucionales que atienden a la lógica higienista. Abordemos a continuación las más sustanciales.

El higienismo establece una relación de causalidad única entre las condiciones de vida material de las clases populares y su adhesión a comportamientos consideradas "desviados" y "nocivos" para el propio sujeto y/o el conjunto de la 
sociedad. La institución estudiada aplica esta premisa con una precisión pasmosamente milimétrica. Los profesionales son unánimes al considerar que, en primer lugar, la intervención educativa y terapéutica con los jóvenes está destinada a producir ciertos cambios en ellos que mitiguen la "peligrosidad" que representan para sí mismos y la sociedad; en segundo, que el entorno social, esto es, los diversos ambientes donde transcurre la vida cotidiana de los chavos es una de las causas principales de la "conducta infractora" (p.72, publicación de la institución).

Al mismo tiempo, es significativo señalar la intervención al "interior" de la familia (espacio de corrección por antonomasia de los instigadores morales del siglo XIX) como una pieza fundamental del engranaje en el proceso de "reinserción" del joven. $Y$ es que, no sólo el entorno social es "contaminante", la familia también puede ser un "mal ejemplo", por lo que será necesario, como sostenía una de las psicólogas del centro, "tratar la disfuncionalidad de los padres". ¿Cómo? "Educándolos en el marco de la prevención",25 (trabajador social). Y es que "nosotros sabemos que el núcleo familiar es donde se desatan todos los factores de riesgo y llevan a que el adolescente cometa un delito" (abogada); la esfera familiar "es finalmente donde se desarrollan todas las habilidades y recursos del chavo" (psicóloga).

Esta lógica establece un nexo entre pobreza y dinámicas intrafamiliares marcadas por la violencia y el consumo de drogas. En relación a las familias de procedencia de los jóvenes, se afirma que éstos "sufren una socialización contradictoria que se refleja en sus actitudes y conductas; a veces como forma de defensa y de reacción, otras, como intentos de fuga social y desadecuación pero casi nunca como manifestaciones conscientes y responsables" (p. 47, publicación de la institución).

${ }^{25}$ Cabe volver a señalar en este punto que uno de las condiciones sine qua non para que la institución admita al chico, es el "consentimiento" de los familiares a someterse a "tratamiento". 
Otra de las particularidades higienistas que atraviesa la institución reside en la continua búsqueda de categorías clasificatorias para cuadrar y regular comportamientos, actitudes, dinámicas, etc. A través de esta inercia entomológica encontramos, por ejemplo, que los chicos pueden tener una conducta social, asocial, parasocial, disocial o antisocial; y que su "nivel de riesgo" o de "problemática social" puede ser bajo, medio, alto, muy alto... Al interrogar a los profesionales a cerca de las diferencias y razones de estas, y otras clasificaciones, nos topamos con criterios endebles y poco fundamentados; cuestión que contrasta con las catastróficas consecuencias que este tipo de codificaciones tienen para los individuos sujetos a los procesos de etiquetamiento institucional. Se trata, como ha sostenido Foucault (2000a:297), de "elaboraciones teóricas irrisorias, pero de efectos duramente reales".

El dueto de época prevención y riesgo social son un ejemplo paradigmático de estas categorías esperpénticas, pero implacables. Penetrando con fuerza en las prácticas hegemónicas del campo social, se han consolidado como núcleo teórico de la re-edición de las viejas prácticas de gestión poblacional higienista en las últimas décadas. Estas conceptualizaciones positivistas son parte del utillaje al servicio de los nuevos modelos de control social. Las intervenciones preventivas se dirigen (y se justifican) únicamente hacia ciertos sectores sociales: aquellos donde se supone la existencia de un riesgo. Una focalización que se cierne en torno a poblaciones económicamente empobrecidas, aquellas que no cuentan con una incorporación normalizada en la sociedad. Cuestión que nos permite pensar los conceptos de "prevención" y "riesgo" en función de una clase social concreta sobre la que operar.

La retórica preventiva atraviesa el discurso y la práctica profesional con vigorosos efectos de estigmatización para los sujetos atrapados en ella. Encontramos una de las más inquietantes en la carta de presentación institucional que los profesionales emplean con los chicos y sus familiares: "la misión principal de la entidad es la prevención del delito". Este cometido da cuenta de una de las premisas con la que 
los profesionales intervienen en el sujeto: el joven volverá a delinquir. Ésta opera a modo de premonición que anticipa la aparición de conductas anómalas. Y es que, sobre cada uno de los jóvenes agrupados en el perfil "menor infractor", existe una imputación implícita de futuros comportamientos peligrosos y conflictivos por el hecho de ser pobres, de vivir en una zona suburbial, de tener una familia disfuncional... "La prevención es importante porque puede romper un ciclo intergeneracional [sic] de violencia, adicciones y conductas infractoras. Provee de un excelente espacio para educar a los padres, a la vez que proporciona información a la comunidad y la involucra en la búsqueda de soluciones adecuadas para sus miembros." (p.74, publicación de la institución) Queda justificada de esta forma toda intervención preventiva sobre el joven, y su entorno: esto es, la acción omnipotente de los profesionales para entrometerse en todas las diferentes esferas de la vida del sujeto. Analizaremos con detenimiento éstas y otras inercias proféticas en posteriores apartados.

Otras cuestiones interesantes se desprenden de este ilustre significante. Algunas citas de las publicaciones de la entidad nos permiten ilustrarlas. Una de ellas corresponde a un autor llamado Marchiori (1989), quien afirma que "la prevención del crimen debe comenzar por el descubrimiento temprano de las tendencias agresivas o antisociales de los jóvenes, para prevenir no sólo la conducta problemática o infractora sino su posible reincidencia". (p. 74) Ergo, toda conducta definida como "problemática" o "antisocial" puede devenir delictiva, e incluso reincidente. Nos topamos una vez más con la unívoca relación positivista entre causa y efecto. La causalidad contra la que se lucha (entornos familiares y sociales nocivos) aparece como origen único del fenómeno de la delincuencia juvenil, lo que supone simplificar hasta rozar lo absurdo un asunto mucho más complejo. Bajo este simplismo exagerado el procedimiento a seguir deviene evidente e incuestionable: implementar "actividades que impidan el desarrollo de un patrón fijo de comportamiento ilegal” (p.74, publicación de la institución).

De la definición de prevención social elaborada por la institución se desprende nuestra última observación. Ésta es precisada como el conjunto de "estrategias 
que tienen por objeto evitar o impedir un evento, percibido o definido como inaceptable o, por lo menos contener o reducir los daños derivados del evento. Si se quiere ser eficaz, se debe devolver capacidad y competencia a la gente, capacitándola a fin de que pueda utilizar lo mejor posible sus recursos" (p.73, publicación de la institución). De donde términos como "eficacia", "capacidad" o "competencia", darían cuenta de la concepción institucional del sujeto: una suerte de minusválido social al que hay que instruir y entrenar en la gestión de sus capacidades, al parecer seriamente mermadas. Se trata de un sujeto "deficitario".

El significante riesgo social es otra de las categorías ubicuas que cuentan con un uso recurrente entre los profesionales del campo social contemporáneo. La prevención tiene por objeto detectar riesgos sociales, por lo que ambas categorías terminan conformando un dúo indisoluble dentro del variado inventario de categorías omniexplicativas de la teoría social positivista.

Bajo esta lógica determinista, la categoría "jóvenes en riesgo" es concebida por la institución estudiada como un grupo homogéneo y predeterminado por su situación de clase: "Ante situaciones estructurales que determinan sus vidas, estos grupos desarrollan diferentes respuestas sociales (representadas básicamente en la conducta social) matizadas por su procedencia sociocultural'. (p. 37, publicación de la institución) Sin embargo, la rotundidad de estas aseveraciones, y el uso reiterado del término, contrasta con las dificultades de los profesionales en el intento de definirla. Cuando fueron interpelados sobre este significante, no pudieron dar cuenta de su definición: "cuando ocurren conductas que pueden resultar problemáticas en un determinado entorno" (trabajador social); "son situaciones que ponen en riesgo a los adolescentes" (psicóloga); "situaciones que pueden derivar en conductas problemáticas o infractoras" (trabajadora social). Con la esperanza de encontrar una definición más acotada sobre riesgo social, consultamos una de las publicaciones del la entidad donde hallamos una acepción más difusa, si cabe, que las anteriores. Toman la definición del término de un texto 
de Berga (2003) ${ }^{26}$ : "El termino riesgo social es utilizado para referirse tanto a circunstancias en que el individuo o el grupo se considera afectado por las condiciones del entorno social en el que vive (frecuentemente en referencia a situaciones de dificultad social), como a las consecuencias que puede tener su conducta para la sociedad (dando lugar a situaciones de conflicto social'. Líneas más abajo: "la noción de riesgo social se encuentra intimamente relacionada con la exclusión social" (p. 36). En páginas posteriores encontramos: "se habla de riesgo social como contingencia o proximidad a un daño, el estar expuesto a "algo". (...) Ese estar expuesto a "algo" puede derivar en un daño, aunque no necesariamente" (p. 52).

Son dos las inferencias que podemos realizar: 1. El riesgo social, al parecer, afecta únicamente a los "excluidos". 2. Cualquier evento puede representar un riesgo; esa suerte de ente informe que acecha a los jóvenes, individuos que sin las facultades y el intelecto necesario para discernir entre situaciones peligrosas y seguras, se vuelven vulnerables a todo tipo de amenaza. Podemos retomar la idea de Núñez (2004b:129) al señalar que el éxito de este tipo de significantes reside en no saber qué significan y qué acotan. Términos, en última instancia, idóneos para sostener un pensamiento único y el empirismo ciego que lo sustenta.

No podemos finalizar este recorrido por la geografía de los significantes estrella del campo social, sin nombrar a otros de los omnipresentes: la resiliencia, término de las ciencias físicas exportado a la psicología en la década de los setenta. Esta peculiar categoría pretende dar cuenta de la capacidad de los sujetos para sobreponerse a todo tipo contratiempos, e incluso a resultar fortalecidos por los mismos. La institución coloca la resiliencia como una virtud a cultivar en los chicos. Con este fin será necesario fomentar entre otros factores, la moralidad, entendida como "la capacidad para desearle a otros el mismo bien que se desea para sí mismo y comprometerse con valores específicos, unida a la capacidad para darle sentido a la propia vida" (p.60, publicación de la institución). La resiliencia aparece

${ }^{26}$ El título del libro habla por si solo: "Aprendiendo a ser buenas: los procesos de riesgo social en las adolescentes". 
entonces como una suerte de lo que Karsz (2007:128) ha llamado, resurrección laicizada. Se trata de enderezar al otro... "de amonestar y de rectificar, de transformar a las personas en seres relativamente nuevos, de ayudarlas a estar otra vez en pie, de poner derecho lo que fue torcido (por las deficiencias familiares, la droga, la prostitución, la delincuencia,...). (Ibíd.)

Y es que el higienismo, ataviado con sus categorías contemporáneas, trata de poner orden y rectitud allá donde no lo hay. "Esto implica un combate permanente, la insaciable pasión de hacer el bien. (...) Se trata de devolver su humanidad a todos aquellos que hoy están despojados de ella, a todos a quienes les falta lo esencial. Una tarea titánica. Porque lo que preocupa (...) es justamente lo esencial, lo verdadero, lo humano; esto es lo que cuenta en última instancia, a través -y más allá- de los problemas reales y concretos de la vivienda, género, empleo, hambre, escolaridad, violencia, sufrimiento subjetivo...". (Karsz, op.cit.:104)

Velar sobre la educación de un hombre, es velar sobre todas sus acciones, es colocarle en una posición en que pueda influir sobre él como se quiera, por la elección de los objetos que se le presentan, y de las ideas que se llegan a formar en su imaginación.

JEREMY BENTHAM

\section{II.a.2. La ilusión del sujeto perspicuo y sus efectos alucinatorios: ¿quién es el otro?}

El trabajo de intervención educativa y terapéutica de los profesionales de la institución viene atravesado por la presunción de trasparencia de sujeto: es posible ver su "interior", conocer su "naturaleza íntima", escrutar su alma... Esta idea sugiere que el "operador" puede incidir en lo más profundo del joven para lograr cuestiones tan "audaces" como re-estructurar su personalidad o transformar su interior. Se trata de un sujeto legible a la mirada del trabajador del campo 
social, además de, y esto es fundamental, modelable. Si la "interioridad" del sujeto puede ser objeto de aprehensión, esto es, ver sus entrañas y conocer las dinámicas oscuras que marcan su comportamiento, podrá ser también corregido. El tratamiento se encamina entonces a incidir en su interior para recalificarlo moralmente, y hacer de él un ser "virtuoso". Objetamos a estos planteamientos alucinatorios su premisa de perspicuidad. Ya Kant arguyó en el siglo XVIII la imposibilidad, "aun ejercitando el examen más riguroso", de llegar por completo a los más recónditos motivos que guían las acciones de los seres humanos, "cuando se trata de valor moral no importan las acciones, que se ven, sino aquellos íntimos principios de las mismas que no se ven". (Kant, 2007 [1788]:32) A esta discrepancia, añadimos el desmarque de otras de las presunciones subyacentes a la ilusión de trasparencia: el ideal de un sujeto que no engaña. "El sujeto, más allá de su conciencia, no es transparente ni para sí mismo; (...) La resistencia de lo íntimo, la reserva de lo privado, siempre se guarda aunque sea sin proponérselo". (Tizio, 2008)

Sin embargo, la idea del sujeto diáfano, hace que la suspicaz mirada del profesional, y su inagotable sed de conocimiento, no deje ningún ámbito de la vida del joven sin escudriñar. Es necesario examinar cada una de sus esferas para que nada quede relegado a la oscuridad. De ahí el exhaustivo inventario que realizan desde las primeras entrevistas con los chavos sobre sus relaciones familiares, entorno social, adscripciones religiosas, grupo de pares, y todo el catálogo de sus orientaciones, disposiciones y preferencias (morales). Proceder en el que, por otro lado, encontramos los ecos de la caridad, esa práctica "intransigente, e incluso, agresiva, invasora, atropelladora con sus interlocutores" (Karsz, op.cit.:104). ${ }^{27}$

27 Los jóvenes deben mostrarse ininterrumpidamente ante la mirada de los profesionales (incluyendo la propia mirada del antropólogo que los "cosifica" como un objeto de estudio y los observa impúdicamente). Se trata de la existencia tácita de un derecho de intromisión del especialista en "excluidos sociales", donde éstos quedan exentos del derecho a su privacidad y a establecer los límites de lo que él considera como injerencia o no. El "operador" se arroga el derecho de realizar preguntas indiscretas, indagar en "mundo interior", observar conductas intimas... y el "menos infractor" a dar explicaciones, justificar su modo de vida, a abrir su intimidad, etc. Como dice Manuel Delgado (op.cit.), se les obliga a exhibir lo que los demás podemos mantener oculto. 
Es interesante advertir como, bajo esta ilusión de transparencia, los profesionales interpretan el "correcto" comportamiento del joven (acorde a la reglamentación y disciplina de la institución) como manifestación rotunda del éxito del tratamiento. Por el contrario, toda discordancia es entendida como falta de progreso en su proceso de corrección. "La apariencia social adviene estatuto ontológico del sujeto"28 (Núñez, 1990:94), es decir, el comportamiento que el joven despliega en el marco institucional, termina definiendo su "interioridad". Es por ello que la vigilancia debe ser continua.

E: ¿En qué aspectos aprecias que el tratamiento del chavo va bien?

$P$ : En su fisionomía, su apariencia, su forma de hablar, y sobre todo la actitud que tienen. Antes pasaban y te aventaban. $Y$ ahora hasta te hacen una caricia. Son actitudes, por ejemplo, "buenos días", saludan. Me da risa porque me avisan cuando quieren salir al baño. Me dicen: "voy al baño". Son esas pequeñas actitudes... que te pidan permiso para ir al baño es una cosa pequeña, pero refleja un gran cambio en el chavo.

(Psicóloga)

E: ¿Cómo sabes que el tratamiento ha concluido con éxito?

A: En principio, en su aspecto físico lo notas... lo notas de inmediato. El chico deja de ser esa persona que se conduce agresiva, o tal vez, que se conduce insegura.

(Abogada)

Esta postura nos remite a lo Berndfeld (1973) llamó pedagogía cuartelaría, en alusión a las lógicas que miden sus logros educativos en función de la obediencia de los sujetos a la normativa institucional, confundiendo así, los efectos pedagógicos con los comportamientos propios del sometimiento. ${ }^{29}$ Se trata de la vuelta al viejo orden de la mirada y el efecto moralizador de la vigilancia benthaniana. (Foucault, 2000b) Mirada que fue dirigida con especial enjundia hacia aquellos sectores oscuros y depravados de la sociedad: las clases subalternas, objeto de disciplinamiento, corrección y salvación moral del detritus

\footnotetext{
${ }^{28}$ Socialidad y subjetividad, las dos dimensiones del sujeto kantiano, se asimilan.

${ }^{29}$ Como veremos en la segunda parte de este capítulo, los chavos se percatan rápidamente de los criterios conductuales a través de los cuales se mide el "éxito" de su tratamiento, dando lugar a interpretaciones dramáticas altamente eficaces del papel que se espera de ellos.
} 
que ellas mismas generaban. ${ }^{30}$ Ya hemos señalado que los individuos susceptibles de ser recalificados moralmente son reclutados en los mismos sectores sociales que siglos atrás.

La investigación nos muestra los efectos alucinatorios de una mirada panóptica que continúa confiriendo un estatuto ontológico a aquello que el sujeto manifiesta ante los ojos de su vigilante. En esta clave podemos entender el forzamiento al que el joven es sometido durante las primeras entrevistas con los profesionales para que "confiese" su autoría en el delito imputado (esta conminación comienza en el primer contacto del joven con los “operadores" de la institución durante la reclusión en el Consejo de Menores). Es importante mencionar en este punto que, dicha autoinculpación es condicio sine qua non para que el chavo sea admitido en la institución. Si no se declara culpable, no le será brindado el servicio.

Cuando los profesionales son interrogados por la necesidad de esta "confesión", apelan a razones tales como la honestidad y la verdad. Sostienen que los chavos mienten per se y que niegan sistemáticamente su implicación en los hechos (ergo hay una presunción a priori de que son culpables del delito imputado, independientemente de que el joven niegue su relación con los hechos, e incluso de que el juez todavía no haya dictaminado su culpabilidad).

El razonamiento de los profesionales sobre esta exigencia es maravillosamente simple. Por un lado, forzándoles a que digan La Verdad aprenden a ser honestos. Por otro, auto-adjudicándose la autoría del delito (supuestamente) cometido, no sólo se hacen cargo de él, sino que aprenden a "responsabilizarse" de la globalidad de sus actos. Una trabajadora social lo sintetizaba de la siguiente manera: "El chavo abre su intimidad y honestidad cuando reconoce su culpabilidad". Se piensa que si se puede nombrar algo, en este caso su supuesta implicación en los hechos imputados, entonces se sabe qué hacer con eso. Como

\footnotetext{
${ }^{30}$ Aunque Bentham no fue el primero en otorgar un lugar privilegiado a la mirada vigilante. Los manuales medievales para los inquisidores instaban a los agentes de la ideología oficial a espiar y observar con cuidado los gestos de los marginados (especialmente los herejes). Estos textos incluian descripciones detalladas sobre la gestualidad, modos de hablar, etc. que permitian distinguir y aislar a los indeseables. (le Goff, 2008:178)
} 
si por el solo hecho de nombrarlo se transformara en real y pudiera dar cuenta además, de la certeza del abordaje. (Ayciriex y Moretti, 2004:60)

Pero no terminan aquí las ventajas de la lógica de la perspicuidad. La autoinculpación coadyuva además al rompimiento de las resistencias que el joven presenta al trabajo educativo y terapéutico.

E: ¿Cuándo consideras que un chavo está "reinsertado"?

$P$ : Cuando se responsabiliza.

E: ¿Y cómo sabes que se ha responsabilizado?

P: Tan sencillo como cuando le preguntas cómo fue su infracción. Entonces empiezan a narrar y dice "creo que si tengo responsabilidad". Entonces ahi es cuando realmente te das cuenta de que el chavo está reinsertado.

(Psicóloga)

Sin embargo, la infalible y objetiva mirada de los profesionales está atravesada por las representaciones hegemónicas sobre cómo deben ser los desviados. La categoría "menor infractor" cuenta con sus "inherencias" particulares que contribuyen a forjar una determinada construcción (a priori) del otro. Examinemos dos de estas características inmanentes, aparentemente paradójicas, que colonizan la concepción de los profesionales: culpable y víctima.

La premisa de partida es que el chavo es siempre culpable, no dice la verdad.

E: ¿Y no cabe la posibilidad que el chavo no haya cometido el delito?

$P$ : No ese día. De ahí depende tu habilidad [para ver]. Entonces podría parecer injusto: 'Yo no robé: Pero de verdad, a todos los que he atendido, algunos ese dia no lo hicieron, pero ya 10 habian hecho otras veces.

(Psicóloga)

La palabra de los chicos está permanentemente bajo sospecha, es puesta en entredicho con singular frecuencia. Por si fuera poco, su crimen "no solamente les aqueja a ellos; es a toda la familia, a toda la sociedad" (abogada), acusación recurrente que podemos ubicar en sintonía con la construcción de los jóvenes 
como "nuevo enemigo" de la sociedad de la que tan agudamente nos ha alertado Reguillo. (2005; 2007)

El sujeto es paradójicamente culpable, al mismo tiempo que víctima. Es víctima de una familia "disfuncional", de una colonia marginal, de unas habilidades y competencias sociales deficitarias... En definitiva: víctima de un entorno pernicioso. Ambas representaciones despojan de responsabilidad al sujeto, que será colocado en el lugar de objeto sobre el que operar.

"Los veo como chavos que tienen muchas carencias, es una forma de expresar su inconformidad. No la mejor manera, no les estoy dando su avión, pobrecitos, han sufrido mucho. Pero desde ahí es como ver dónde se ha educado".

(Psicóloga)

La representación como víctima vuelve a justificar la intervención. En la primera parte de este trabajo sosteníamos que para ser objeto de reinserción, el sujeto debe previamente ser fragilizado, inferiorizado, esto es, interpelado como joven necesitado, perdido, desventurado, excluido, desdichado... y por lo tanto protegido por el "buen" criterio profesional que, en nombre de su BIEN, sabe qué es lo que le conviene.

"Es una persona [en relación a la "tipología" de jóvenes atendidos por la institución] demasiado susceptible. Es una persona que puede ser manejable. Entonces en base a ello se les debe orientar para que ellos conozcan sí es bueno o malo lo que van a decidir".

(Abogada)

"La única alternativa que conocen es lo ilegal, las drogas, toda la violencia..."

(Psicóloga)

P: “(...) y a ratos los veo como sinsentido".

E: ¿A qué te refieres?

$P$ : Como que no tuvieran un sentido, como ¿para qué te esfuerzas si las cosas están mal? Y pareciera que estamos hablando ya de adultos de 50 años, cuyas conductas no se puede modificar. 
E: ¿Te refieres a chavos sin intereses, sin metas?

$P$ : Más que sin metas es, ¿para qué modifico si todo está mal? Como si estuvieran en una desesperanza de que las cosas no pueden ser distintas".

(Psicóloga)

Alguien irresponsable, sinsentido, culpable del delito, víctima de su entorno... en definitiva, alguien del que no se espera mucho, son representaciones institucionales que sólo producen desesperanza y displicencia.

La concepción de víctima nos remite a aquel destinado al sacrificio. Homo sacer despojado de todo valor político para el cual no es necesario habilitar nuevas oportunidades sociales o culturales, sino intervenir en sus actitudes con el fin de producir individuos conformes con el destino social que se les adjudica. Gallén (op.cit.:78) sostiene que la misión de los profesionales del campo social es la de apaciguar al "excluido", disuadirlo para que acepte integrarse en un orden inferior y más precario. Con ello se adscribe a la idea lévistrossiana por la cual "el enfermo puede ser curado; el inadaptado o el inestable sólo puede ser persuadido" (citado en Gallén, Ibíd.).

En este sentido es ilustrativo señalar que la respuesta unánime de los profesionales cuando fueron interpelados por lo que esperan de los chicos que atienden fue: "que no reincidan", que se conduzcan por el camino recto. Cabe preguntarse sí, además de "no reincidir", puede esperarse algo más de estos jóvenes. ¿Existe una apuesta institucional para que puedan ocupar otros lugares sociales más allá del resto social? Como veremos en la recta final de este subcapítulo, las certezas institucionales sobre quién es el otro, invalidan la emergencia de la apuesta necesaria de todo trabajo educativo. A saber: que el sujeto construya nuevas y particulares filiaciones sociales y culturales con los saberes que le son transmitidos.

Cerramos este recorrido apuntando el mecanismo que, en última instancia, opera en la construcción del otro que venimos analizando. Podemos referirlo con el nombre de proceso de totalización, procedimiento por el cual el sujeto es definido a partir de un rasgo distintivo o de una dificultad determinada (conducta 
problemática, adicción a la droga...) que le otorga una nueva identidad que absorbe al resto e ignora las otras cosas que también es. El joven será concebido entonces como "delincuente", "problemático", "drogadicto", etc. Este mecanismo atiende a la tesis de Becker (op.cit.:40) por la cual el estatus desviado es un estatus principal. La posesión de un rasgo desviado totaliza al sujeto, de modo que se lo supone automáticamente poseedor de otros rasgos indeseables supuestamente asociados al mismo. El joven pasa a ser "la encarnación, la corporalización, de una categoría social que lo engloba y define más allá de sí mismo" (Santamaría, op.cit.:74), ya no es alguien particular y enigmático. Impugnado en su totalidad como ser humano, sólo queda lugar para emerja como el "problema social".

Hemos fracasado sobre los bancos de arena del racionalismo demos un paso atrás y volvamos a tocar la roca abrupta del misterio.

URS VON BALTHASAR

\section{II.a.3. Premoniciones, augurios y otras profecías: la emergencia de verdades apodícticas}

Sabemos de los usos sociales y políticos de la ciencia como eficientes mecanismos para naturalizar un orden social determinado. Los aparatos taxonómicos de la teoría social, con su barroco inventario de nomenclaturas, han contribuido a delimitar categorías sociales y a legitimar su disposición en un orden de subordinaciones, exclusiones y jerarquías. Muchas de las clasificaciones que se utilizan en el campo del trabajo social, importadas entre otras de la antropología y la pedagogía, funcionan como retóricas de verdad, esto es, como conceptualizaciones investidas de un carácter de evidencia. Estos 
pronunciamientos irrefutables, además de esconder las trampas más insidiosas, obturan los espacios de ignorancia indispensables para dar paso a la emergencia nuevos interrogantes.

De esta manera, significantes como "joven en riesgo social", "menor infractor", "adolescente problemático" o "familia disfuncional", aparecen ante la mirada de los profesionales del campo social como una realidad en sí misma. Estas categorías son pensadas en su positividad, es decir, como objetos externos que están allí disponibles para ser capturados por las redes de visibilidad de las teorias. Y es dentro de estos límites que, como arguye Diker (2004:9), algunos jóvenes se vuelven adolescencia, mientras que otros se vuelven "menores", "delincuentes", "excluidos", o "inadaptados". Sabemos que estas prácticas nominativas crean una realidad propia, y con ella, determinados efectos. $Y$ es que, el "discurso, en tanto proceso de producción de sentido, produce efectos de realidad" (Núñez, 2004b:125), representaciones y significaciones que crean imágenes y símbolos con consecuencias reales en el plano social, institucional, pero también en la subjetividad de los individuos.

Cuando se nombra a los chavos como "menores infractores" y se los representa a partir de esa nominación, se aspira a aprehenderlos como realidad "objetiva", obviando las interpretaciones inobjetables y las certezas necesariamente válidas que guían el trabajo de intervención de los profesionales. Ubicamos esta postura en sintonía con lo que Karsz (2007:150) denomina "ideal de maestría", un lugar profesional cercano al "saberlo todo", a intervenir antes de que pase nada; una posición, dice el autor, que "implica una extrema dificultad para aprender otra cosa que lo que ya se sabe, un principio paralizante por excelencia”.

La declaración institucional de trabajar para la prevención del delito esconde uno de estos supuestos incondicionalmente ciertos: el sujeto volverá a delinquir (si no se lo "trata"). 
"Entonces, si este chico sale [del Consejo Tutelar] y no hay un medio de contención, en este caso una familia, una figura como son los padres, la abuela, el tío... y regresa a ese entorno familiar pues suponemos que vuelve a delinquir, es decir, reincide".

(Abogada)

Una de las psicólogas al ser preguntada por el modo en el que trabaja la "planificación familiar" con los jóvenes: "La planificación familiar es que utilicen métodos anticonceptivos y que vean también los gastos que conlleva tener un hijo. Dicen "qué bonito está mi hijo". Pero, ¿a tus 16 años?... iya dos hijos!... ¿cuáles son los gastos?... te tienes que dar cuenta, porque eso te hace sentir más presionado, y eso te va a llevar a robar para mirar por tus hijos, para que no les falte alimento".

En una sesión dirigida a los familiares de los chavos en el momento en el que éstos están detenidos en el Consejo de Menores, un psicólogo les interpela: "hay que romper la espiral. Cuando lo van a ver al Ministerio Público le llevan comida... buena comida, lo consienten, lo apapachan, le prestan mucha atención... Asi el chavo volverá a delinquir porque sabe que de esa manera ustedes le prestarán atención".

"Adolescente en riesgo" o "joven asocial", son figuras construidas por un discurso de certezas apodícticas que vienen a confirmar los supuestos herméticos de trabajadores sociales y psicólogos, anulándose así la posibilidad de elaborar cualquier hipótesis sobre el sujeto que permita orientar el trabajo educativo. El encorsetamiento en teorias y representaciones incontrovertibles inhabilita la operación de encuentro con el otro desde un lugar diferente. Para los "operadores" el sujeto no depara ninguna sorpresa; tampoco ningún enigma. ${ }^{31}$ No hay interrogante, duda o incertidumbre por la que se dejen atravesar, ni en relación a quién es el joven que atienden (sus intereses, inquietudes...), ni en relación a las categorias omniexplicativas que guían su intervención. Esta posición de hermetismo y certidumbre constituye uno de los principales escollos para la tarea educativa, enemiga por definición de lo definitivo, lo imposible y lo determinado.

En estas nominaciones irreversibles reside una de las claves para entender la insistencia de los profesionales en el síntoma, fijación que coloniza todos los espacios de trabajo terapéutico y educativo de la institución. El sujeto y su

${ }^{31}$ Recordemos que es trasparente a la mirada y previsible en sus conductas. 
"interioridad" son aprehendidos en los términos de la dificultad social que manifiesta: "menor de conducta problemática". Sabemos que las expectativas que se ciernen sobre un sujeto que es esencializado como "disfuncional" o "inadaptado", es que siga siéndolo. De esta manera, la intervención con los jóvenes gravita insistentemente en torno a la cuestión conductual, postura que, resta decir, anula la apertura de espacios donde dar cabida a los intereses y deseos de los chavos.

Bernfeld, en la obra ya citada (1973), alertó sobre la inconveniencia de insistir sobre el síntoma en la atención educativa de la llamada "inadaptación". Para el autor, esta posición conduce a fijar al sujeto en el punto de la transgresión de la norma social -elemento que, por otro lado, forma parte de la normalidad de los adolescentes. Para la institución y sus profesionales, el joven es un "menor infractor", esto es, es un sujeto que ha trasgredido la norma, un sujeto que no dice la verdad, por lo que aspectos como la disciplina y la sinceridad son obsesivamente abordados en los espacios "pisico-pedagógicos-educativos". Como ya situamos con anterioridad, el "éxito" del tratamiento es medido en términos conductuales, por lo que el trabajo de los profesionales va encaminado a forjar un chavo disciplinado (y moralmente recalificado). Sus comportamientos son juzgados desde una moral acartonada que establece una dicotomía clara entre el "bien" y el "mal", de donde sólo se ofrece una opción: el sometimiento a las normas y dejarse guiar a un "buen puerto", al lugar que se supone más adecuado para él. Todo ello en nombre de su bien. Se vuelve a repetir el malentendido básico al que se refieren Díaz y Hillert (1993:16): la creencia de que todos los adolescentes deben subirse al mismo tren para evitar descarrilamientos.

Interjecciones como "siéntate bien", "tira el chicle", "quítate la gorra", "pórtate bien", "no entres con aretes", "habla bien, no estamos en tu colonia"..., atraviesan de forma recurrente las interacciones de los "operadores" con los chicos. Y es que, a pesar de las amonestaciones, los jóvenes continúan acudiendo a las sesiones ataviados con gorras, comiendo chicle, y "portándose mal". Como sostuvimos en el capítulo anterior, aquel clasificado como "joven problemático" acaba inevitablemente convirtiéndose en lo que dicen de él que es, es decir, acaba 
"problematizándose"; adoptando la identidad que los demás le atribuyen y actuando como tal. Estas cuestiones sintomáticas son producidas por el propio funcionamiento institucional. La insistencia e intensidad con la que se opera sobre estos síntomas, termina cronificando al sujeto en los mismos. (Núñez, 1990:94) El chavo pasa a ser efectivamente la encarnación de la categoría que lo produce como "menor infractor" o "joven de conducta problemática". Retórica que etiqueta, al mismo tiempo que sentencia y predispone. Como veremos en la segunda parte de la presente investigación, los chavos terminan identificándose (parcialmente) con estos significantes. Se trata de las profecias autocumplidas de las que, con excelentes trabajos, nos alertaron los sociólogos de la desviación.

A partir de estas presunciones incuestionables se confecciona una plaza institucional para el sujeto a la medida de la definición-construcción del problema: "joven asocial". Se trata de una plaza estándar construida a priori; no es un lugar vacio que permita albergar sus intereses, elecciones... su palabra (espacio imprescindibles en la construcción de nuevas filiaciones sociales). Se trata más bien de una convocatoria encorsetada, en donde se hará encajar al joven quiera o no (a lo que responderá con las tácticas que le permitan resistirse a este forzamiento).

Otra de las certidumbres inquietantes que habitan la institución reside en la capacidad omnisciente del diagnóstico como productor indiscutible de saber en relación al sujeto. Esta técnica evaluativa tiene la capacidad de revelar quién es "realmente" el sujeto, y las acciones a seguir. Encontramos manifestaciones institucionales significativas de elogio a este tipo de saber técnico en adscripciones a citas como la siguiente: "muchos de los problemas de la identificación de niños antisociales pueden resolverse a través de criterios diagnósticos estándares o mediante una investigación que identifique constelaciones específicas, medibles y replicables de conductas que ayuden a definir los tipos específicas de disfunción". (Kazdin (1998), citado en publicación de la institución) Asimismo, una de las abogadas del centro comenta en referencia 
al diagnóstico: "(...) para mí son vitales porque yo tengo acceso a ellos y siempre los leo porque me dan una panorámica de mi verdadero defendido, de quién es. Pero a la vez, me puede decir si es verdad lo que chavo me estaba refiriendo, o bien hay cuestiones que no me quiso abrir".

La actividad cognoscitiva del diagnóstico tiene por objeto elaborar "evidencias" sobre el sujeto que, en muchos casos, terminan por adquirir un estatus de predicción. Sus efectos nominativos contribuyen a edificar fronteras inexpugnables y premoniciones varias acerca de los comportamientos que se esperan de los chavos. Nos topamos con la alucinación positivista por la cual, aplicando cuestionarios, test y otros artilugios, podremos asomarnos al "interior" del chavo. Una presunción que da cuenta de la posibilidad de aprehender el mundo del sujeto como una realidad objetiva. Las inmodestias omniscientes del diagnóstico borran al sujeto y su particularidad. Se construye un otro a imagen y semejanza del discurso en el que se inscriben los profesionales, confirmando así los supuestos que incardinan sus preceptos teóricos (y morales). Como sostiene de Leo (1985:67), el diagnóstico contribuye a elaborar, sostener y confirmar una imagen del joven "delincuente", con todos los elementos de rigidez, esquematismo y prejuicio implícitos en la misma. El saber se elabora en conformidad a las premisas ideológicas y científicas construidas en torno a la desviación. Oráculo positivista, el diagnóstico sólo arroja certezas incuestionables, no hipótesis de trabajo (piedra angular de la tarea educativa).

La aplicación de la "Escala de Funcionamiento Familiar" utilizado por la institución para "diagnosticar" el grado de "funcionalidad" de las familias de los jóvenes, encarna un ilustrativo (e irrisorio) ejemplo de las consideraciones que venimos desarrollando. Este artilugio positivista trata de medir cuán "funcional" es una familia en aéreas tales como la imposición de límites, la comunicación, la afectividad, la jerarquía, los modos de control de conducta $^{32}$ y la psicopatología ${ }^{33}$,

32 Entendido como los "patrones que una familia adopta para manejar sus impulsos y para mantener modelos de qué es bueno y qué es malo, y para luchar contra las situaciones físicas peligrosas". (Extracto del "Manual para la Escala de Funcionamiento Familiar") 
entre otros. Para ello, el "operador" realiza un tedioso e intimidatorio cuestionario de cuarenta preguntas, que la familia al completo, incluido el joven, deberá responder. Las opciones de respuesta son cerradas (1. El padre, 2. La madre, 3. Los hijos, 4. Todos los miembros, 5. Ningún miembro).

De esta suerte, la respuesta a la pregunta 34: ¿¿Quién/es en la familia se abrazan espontáneamente?" nos permitirá saber cuál es el grado de "funcionalidad afectiva" de la familia (en una escala del 1 al 4). A través de la respuesta a la cuestión número 39: “¿Quién/es de la familia han presentado algún problema emocional?", y la número 40: “¿Quién/es en la familia se aísla?”, podremos conocer el grado de psicopatología familiar. Incluso, podemos acercarnos a la jerarquía familiar a partir de la pregunta 4: "Si se reúne la familia para ver la TV, ¿quién decide el programa?" Se trata de un escabroso juego de inferencias a partir, no sólo de las respuestas, sino también de los comportamientos que los miembros de la familia sostuvieron al contestarlas. Sus actitudes terminan por globalizarlos o totalizarlos al colegir aspectos de carácter subjetivo del modo en el que contestaron el cuestionario.

En otro orden de cosas, preguntas como "¿Se han llegado a golpear?" ( $\left.n^{\circ} 35\right)$; "¿Hay alguien en la familia que se embriague con alcohol o tome otro tipo de estimulantes?" ( $\left.n^{\circ} 36\right)$ o "¿Quién/es han tenido problemas con la autoridad?" ( $n^{\circ}$ 37), dan cuenta del supuesto que engarza el cuarteto neohigienista: pobrezaviolencia intrafamiliar-drogadicción-criminalidad.

Concluimos este relato de certezas apodícticas con una de las más inquietantes. Podríamos sintetizarla con el epígrafe de "sujeto aquiescente". Los profesionales dan por supuesto que el joven siempre consiente a la intervención "psicopedagógico-educativa". Es más, ni siquiera contemplan en su discurso, ni en su práctica esta condición medular para que el trabajo educativo sea posible. ${ }^{34}$

\footnotetext{
33 "Se habla de ello cuando los conflictos no se resuelven debido a la rigidez de patrones de interacción". (Extracto del "Manual para la Escala de Funcionamiento Familiar")

${ }^{34}$ Es importante destacar que al interpelar a los profesionales sobre alguna cuestión relacionada con el consentimiento de los chavos que atienden, ninguno de los entrevistados entendió la pregunta en la primera ocasión que fue formulada. La noción consentimiento no forma parte de su universo de premisas.
} 
Sabemos que sin la anuencia del sujeto a la acción educativa, todo trabajo será infructuoso. Retomemos dos ideas cardinales al respecto. La voluntad del hombre no puede ser violentada (Hegel, 1993) [1832] y la moralidad es inaccesible al intento de coacción (Kant, op.cit.). Es decir, se puede forzar al sujeto a modificar sus acciones, pero resulta imposible, sin su consentimiento, forzarle a que modifique su subjetividad. Sin embargo, para la institución la noción de "menor infractor" remite a un sujeto intrínsecamente aquiescente, inteligible no sólo a la mirada del profesional, sino también a su poder. Las resistencias que el chavo pudiera implementar siempre serán superadas, eliminadas por el insistente trabajo de "concientización" o "sensibilización" encaminado a que el joven "pueda ver su problemática", a que "se de cuenta"... se trata de, a fuerza de sometimiento, "destrabarlo" ${ }^{35}$ (¿cómo si fuera una cañería embozada?) para lograr el cambio deseado: un sujeto disciplinado.

"E: ¿Qué sucede cuando el chavo no consiente al trabajo educativo o terapéutico?

P: Pues es mucha labor... Es como decir: 'finalmente ya estás aquí. ¿Qué podemos hacer? Por más que patalees, por más que te quejes, ¿qué podemos hacer?' $Y$ entonces sí concientizarlo: 'Te has venido comportando asi'. (...) Tienes que tener mucho en cuenta la valoración y el diagnóstico para ver cómo se venía comportando antes, y ahí retomar cómo se sigue comportando y hacerle ver cuáles son sus situaciones de riesgo".

E: Entonces si hay un no consentimiento por parte del chavo, ¿tu labor sería la de hacer un trabajo de 'concientización'?

P: Si.

E: ¿Y termina consistiendo?

P: Sí.

E: ¿Siempre?

P: Sí.

(Psicóloga)

Lo normal en el trabajo social educativo, es, nos recuerda (Meirieu, 1998:73), que la cosa no funcione, que "el otro se resista, se esconda o se revele. Lo normal es

\footnotetext{
${ }^{35}$ Los entrecomillados hacen referencia a los significantes más utilizados por los profesionales durante el trabajo de campo.

${ }^{36}$ La pregunta tuvo que ser explicada.
} 
que la persona que se construye frente a nosotros no se deje llevar, o incluso se nos oponga, a veces, simplemente, para recordarnos que no es un objeto en construcción sino un sujeto que se construye". Otorgarle al sujeto la posibilidad de no consentir, de negarse al intento de redención, supone la volatilización del sujeto ideal (el fenotipo de "menor infractor"), el Pigmalión necesario para que la cosa salga bien. Aceptar su negativa a la intervención, supone reescribir el guión, reinventar los roles... significa pasar de un movimiento unilateral y controlado, a un movimiento sísmico, donde el profesional ni puede controlar al sujeto ni controlarse a sí mismo. ${ }^{37}$ Admitir que el sujeto no consiente, es suponer un sujeto con deseo, con capacidad de elección, con inquietudes... alquien que está vivo.

\section{II.a.4. El "déficit" del otro pobre: en regreso de las posiciones educativas pestalozzianas}

Hemos definido el trabajo social educativo como la acción social orientada a la incorporación de los sujetos a la cultura de su tiempo, a través de la transmisión de aquellos saberes socialmente necesarios para que puedan inscribirse y circular por el entramado de su época. Saberes de valor social que otorguen al sujeto su lugar como heredero de los legados culturales, que por derecho, le corresponden. (Núñez, 1990; 1999) Para que la educación pueda hacer a las nuevas generaciones "actuales a su época" (Gramsci, 1973), es necesario acercarlos a la cultura y ofrecerles sus artilugios simbólicos como llaves de acceso a nuevas e insospechadas filiaciones sociales. Se trata, en las bellas palabras de Philiphe Mireau (1998), de "ofrecer un lugar en el mundo y las herramientas para ocuparlo".

Es en el marco de estas consideraciones que podemos platear el vaciamiento cultural de la institución. ${ }^{38}$ La investigación nos muestra la ausencia de aquellos

\footnotetext{
${ }^{37}$ El mecanismo de control a dos bandas (sujeto-profesional) ha sido abordado por Tizio (2008) en relación al uso del protocolo en la práctica educativa.

${ }^{38} \mathrm{Si}$ bien existe un espacio para INEA donde los chicos preparan los exámenes para certificar la secundaria, los profesionales lo consideran un espacio "ajeno" a la institución. La instrucción académica en INEA es un requisito del cumplimiento de la pena, no la posibilidad de poner a los chavos en relación con la cultura.
} 
saberes de valor social que posibiliten a los chicos otros recorridos posibles por lo social amplio. Lo que encontramos es un aleccionamiento en "habilidades", "capacidades" y "competencias" sociales, y cómo no, en la afamada "transmisión de valores" ${ }^{\text {"39 }}$, que desplaza los saberes culturales, para dar lugar a un trabajo educativo de corte moralizante. El joven deviene objeto de intervención y recalificación espiritual, y no un sujeto con derecho a apropiarse del patrimonio cultural que a todo ser humano le corresponde. Lo que encontramos en lugar de la transmisión de los saberes de valor social, es una especie de trabajo moral, travestido de "empatías", "autoestimas", "emociones", y otras dulzuras insistentes e implacables de "quienes están definitivamente seguros de saber lo que es bueno para el otro". (Karsz, op.cit.:128)

Cuando los profesionales de la institución son interrogados acerca de las herramientas que es necesario trasmitir en su tarea para que los chavos se "reinserten" -en referencia a la posibilidad de que circulen por lo social amplio- el inventario del utillaje utilizado gira en torno a cuestiones tan ampulosas como: conocerse a sí mismo; conocer su autoestima; enseñarles identificar y decir "no" a los factores de riesgo; enseñarles a comunicarse; a solucionar conflictos; a identificar y expresar emociones; a empatizar... Lo que los profesionales esperan que hagan con estos "útiles" es, en primer lugar, no "reincidir", para pasar después a cuestiones como encontrar un trabajo (de mesero, albañil, etc.), o formar una familia. No hay horizontes de promoción en la institución que los imaginen más allá del "resto social". Los chavos no son convocados a ocupar otros lugares sociales (acabar la preparatoria, acceder a la universidad, acercarse al arte, a la literatura...). No existe, por lo tanto, la apuesta imprescindible que todo acto educativo requiere: el envite para que los chicos se acerquen, aprendan, reflexionen, piensen... los múltiples desafíos que los saberes de época nos plantean.

${ }^{39}$ De donde el respeto a las normas y las reglas, y la responsabilidad de la infracción serían las más importantes. 
¿Se trata entonces de la vuelta de las viejas posiciones educativas pestalozzianas, aquellas diseñadas a la medida de la pobreza y la exclusión de quien las recibe ${ }^{40}$ Recordemos que una de las principales propuestas de este pedagogo del siglo XVIII fue la de educar al pobre para vivir en su pobreza.

Tomemos un ilustrativo pasaje sobre el concepto institucional de educación en el desarrollo de estas consideraciones. "Se entiende la educación como vía de superación de la persona, así como un factor importante de capacitación para la actividad productiva y como vía de promoción social. Pero también puede llegar a generar expectativas fuera del alcance de las/los niños y adolescentes, que desvíen su atención de otros problemas centrales para su subsistencia cotidiana. Es asi que en ciertas circunstancias la educación deja de ser un bien absoluto para convertirse en un asunto de análisis dentro de la situación de riesgo, sobre todo de aquella población cercana a una situación de exclusión social". (p.57, publicación de la institución -la negrita es mía-) Ergo los pobres necesitan de una educación hecha a "su" medida, no vaya a ser que atravesando mundos literarios o resolviendo problemas matemáticos, encuentren el deseo de saltar los rediles del destinó de ignominia al que son convocados.

Unas páginas después podemos leer que la educación "busca afirmar todos los conocimientos positivos respecto del entorno social, como de la relación con los otros, el trabajo, la recreación, la salud, etc." (p.75) Y es que la función educativa consiste en dar "herramientas [a los jóvenes] para manejarse en su realidad" (trabajador social). Es decir, la educación no es concebida para estos chavos como posibilidad de adquirir las herencias culturales que les permitan emprender otros recorridos, sino como un dispositivo de sujeción a un destino social prefijado.

Sostenemos que estas posturas encierran la idea de que la pobreza es, no sólo una condición social, sino una determinación, un atributo que define a los jóvenes que viven situaciones de pauperización. El sujeto, por el hecho de vivir en un entorno de pobreza, es portador de un déficit económico, social, cultural, moral, y

${ }^{40}$ Claro que, hariamos bien en preguntarnos sí es que alguna vez desaparecieron del todo. 
además, cognitivo. Una cita recogida en una de las publicaciones de la entidad nos permite mostrar esta espinosa cuestión:

"La competencia cognitiva de niños y niñas de familias en ambientes de alto riesgo social se asociaría a politicas de crianza más restrictivas y autoritarias, que aquellas observadas en familias pertenecientes a ambientes de bajo riesgo con niños/as cognitivamente competentes. Situación que obedece en gran medida a la presencia de riesgos reales que enfrentan las familias en ambientes de alto riesgo, frente al cual estas familias actuarían de un modo más restrictivo". (Baldwin, Baldwin y Cole, 1992)

El corolario de las posturas plateadas es tajante: los hijos de familias en "riesgo", esto es, pobres, son deficientes, o si se quiere en un tono más eufémico, menos competentes. La institución es atravesada por una lógica "etnocéntricamiserabilista" que "describe al sujeto subalterno en términos de inferioridad respecto de una cultura legitimada, bajo el principio que sostiene que a la privación material le corresponde la privación cultural". (Grignon y Passeron citado en Duschatzky y Corea, 2007:83) Sostenemos que los efectos de esta dialéctica devaluativa del otro pobre producen implacables efectos de inmovilidad social. El sujeto está definido previamente, se trata de un joven en riesgo social, un chavo con déficit cognitivo, un adolescente incapaz... Estas etiquetas se juegan no sólo en relación a "quién es el otro", sino también a "quién podrá ser". Las categorías despreciativas, nos recuerda Cornu (2004:22), sólo producen desesperanza. Y a la inversa, abrir, habilitar, reconocer y favorecer oportunidades sin prejuzgar, nos alienta a rehuir del fatalismo de profecías autocumplidas. $Y$ es que "el sentido de lo posible multiplica la realidad y abre a otras realidades". (Ibíd.) 


\section{II.b. JÓVENES EN "TRATAMIENTO": MODOS DE HABITAR EL TRÁNSITO INSTITUCIONAL}

La decisión de la comunidad de tomar medidas en relación con un individuo considerado desviado no es un simple acto de censura, sino que constituye un preciso rito de transición que, simultáneamente, lo aparta de su posición social normal y lo lleva a una situación desviada perfectamente definida.

KAI T. ERIKSON

\section{II.b.1. Umbrales: el "tratamiento" como rito de paso}

"Hacer un tratamiento" encaminado a "cambiar las actitudes" para "ser mejores personas". Así podríamos sintetizar, utilizando lo que durante el trabajo de campo fueron sus expresiones más recurrentes, el modo en el que los jóvenes entienden su paso por la institución. El trabajo etnográfico evidencia que los chavos infieren con suficiente precisión cuál es el encargo institucional y, muy especialmente (con claridad meridiana) qué es lo que se espera de ellos durante el tratamiento:

"Que ya no sea igual que antes".

(Salvador, 17 años)

"Que sea mejor persona, que no sea lo mismo que era antes".

(Moisés, 18 años)

Dicen estar en la institución para convertirse en mejores personas y expulsar lo que eran previamente. En este sentido fueron habituales expresiones del tipo: estoy aqui para "cambiar", "ser mejor", "Ilevar una mejor vida"... pues antes "era malo", "me peleaba con otros chavos", "salía en la noche", "no les hacía caso a mis papas", "me drogaba", "era muy rebelde"... Saben que su paso por la entidad supone ser "tratados", "operados" para NO SER lo que eran antes. El ser (totalizado a partir de un estigma) constituye el objeto de intervención: éste será impugnado, interpelado, cuestionado, coaccionado para someterlo a un proceso 
de corrección, optimización que los convierta en "mejor persona", esa alucinación positivista por la que es posible acceder al "interior" del otro y transformarlo sin su consentimiento y voluntad. Al instarlos a que definieran lo que entienden por el encargo de la institución, los chicos arguyen:

"Que... tratan de cambiar a los jóvenes, tratan de renovar su forma de ser, cambiarlos para que se integren otra vez en la sociedad".

(Cristian, 16 años)

"Yo me imagino que más que nada para ser aptos en la sociedad. Y para... pues ya pensar de diferente manera. Pues si antes pensaba nomás en golpear y ese tipo de agresividad, pues ahora piensas en ti y en las demás personas porque todos los días vas a necesitar alguna persona".

(Héctor, 17 años)

"Pues para cambiar mis actitudes, de negativas o positivas... pues antes era más rebelde con mi familia y ya con el tiempo que llevo aquí, cosas buenas las he practicado... las he sacado de mi persona".

(Néstor, 18 años)

La investigación muestra como el paso por la institución es percibido por los chicos como un proceso de mejoramiento en el que deben dar cuenta a los profesionales (a través, como veremos en el siguiente subcapítulo, de una eficaz y dramatizada actuación) de que se están despojando de su antiguo ser (errado, incorrecto, infractor) para ocupar una nueva condición: la de normal. Los chicos saben que lo que se pretende con su paso por la institución es una reubicación moral, un tránsito purificador que los incorpore a un nuevo orden moral. Se trata de una suerte de tránsito exorcizante que los despoje de los viejos sentidos, para instalar otros. Un trance en el que se eliminan y se borran los antiguos atributos que los hacían "malos", para metamorfosearse en chicos "buenos". Las siguientes citas en relación al significante "operador" son altamente ilustrativas:

E: Pero, ¿qué operan?

S: Pues si hablas mal, y eso.

(Salvador, 17 años) 
E: ¿A qué te suena eso de "operador"?

J: Quién sabe... como que nos quieren cambiar. Abrir nuestro cerebro y quitar todo lo malo. Pues algo asi me suena.

(Jordi, 16 años)

El tratamiento, como proceso de transformación, o más correctamente, de trasfiguración, en el que los chavos dicen entrar a la institución como "menores infractores" y salir como "chavos que se portan bien", nos remite a la idea turneana de liminalidad, propia de los ritos de paso. En éstos se procesan los cambios de condición que sufre el sujeto. Es necesario aclarar antes de adentrarnos en el análisis que presentamos a continuación que éste se centra en la trasformación del status, esto es, del lugar que les es asignado a los chavos en el marco de la institución, y no tanto al cambio de estado operado en términos subjetivos. Los chavos interpretan el encargo institucional -el tratamiento- como un proceso transicional al que deben responder. Consideramos sus respuestas en tanto actuación en la que los chavos tratan de dar cuenta del consentimiento a ser "operados" y de la incorporación a un nuevo orden moral gracias a esa intervención. Es el "como sí" de la conducta restaurada de Schechner (1985) utilizada en performances y rituales. Ese "yo portándome como si fuera otro" del que habla el autor, y que es utilizado como una máscara que permite a los sujetos interpretar la conducta esperada de alguien que participa en un ritual. (op.cit.:109110) Nos inclinamos, entonces a hablar de un cambio de condición que no responde tanto a una modificación subjetiva profunda, como a una dramatización de los supuestos cambios operados en el sujeto. Volveremos más tarde sobre este tema.

Turner $(1988,2007)$ basándose en el análisis tripartito ${ }^{41}$ de van Gennep (1986:2082) [1901] para los ritos de paso, exploró magistralmente la naturaleza de la fase liminal. Partiendo de un modelo de sociedad basado en una "estructura de posiciones", consideró el periodo liminal como una "situación interestructural", ${ }^{41}$ El esquema completo de los "rites de passage" caracterizados por van Gennep incluye:
separación (preliminares), margen (liminales) y agregación (postliminales). 
asociada íntimamente a estados y personas marginales; seres que ocupan una situación de inferioridad estructural. En nuestro caso: pobres, adolescentes y delincuentes. En el marco de estas consideraciones, la idea de umbral elaborada por Vergara (2006), e inspirada a su vez en la liminalidad turnerana, nos permite afinar nuestra aproximación a los tránsitos institucionales, y con ella, a los modos en el que los chicos modulan su experiencia a partir del significado que les atribuyen.

Para el autor la noción de umbral da cuenta de un "cronotopo de corta duraciónextensión que produce un cambio -de diversa intensidad- en la condición del ser, es un lugar-tiempo de paso y trasformación". (op.cit.:109) Le atribuye dos sentidos. En primero como tope o límite ${ }^{42}$; y en segundo, como espacio de paso que se ubica entre-dos situaciones o condiciones, donde el sujeto se detiene brevemente, y vive una experiencia generalmente excepcional, no rutinaria. (op.cit.:115) De este último sentido se desprenden varias cuestiones de interés. Sosteníamos que la significación que los chavos elaboran del paso por la institución nos remite a situaciones liminales, en las que el estado del chavo es ambiguo. Los liminoides son personajes ambivalentes (y por tanto, altamente contaminantes). Ya no son lo que eran, pero todavía no son los que serán: ya no es un "delincuente" propiamente dicho, pero tampoco es un "reinsertado" (Turner, 2007:206). Son seres sin un lugar en la estructura. "No son ni una cosa ni otra"; o tal vez "son ambas al mismo tiempo": un desviado en proceso de "normalización". Se encuentran entonces, entre dos puntos "reconocibles del espacio-tiempo de la clasificación estructural”. (op.cit.:208) En este sentido es muy interesante constatar como la mayoría de los chavos entrevistados se identifican, a pesar del tiempo trascurrido desde la imputación del delito, con el significante utilizado por la

\footnotetext{
${ }^{42}$ Para la primera de las acepciones, el límite nos remite al tránsito institucional como experiencia de inmovilización social. Si bien existe una convocatoria para que los chavos dejen de delinquir y circulen por los canales normalizados, el vaciamiento cultural, en el sentido de la ausencia de la trasmisión de contenidos de valor social, y la falta de apuesta institucional para que los chavos puedan ocupar otros lugares más allá del resto, nos remiten a un límite, un tope. Los chavos no viven su recorrido institucional como la plataforma que los catapulte hacia nuevos lugares sociales: continuar con estudios superiores, formarse en un oficio, vincularse a otros circuitos culturales... Más bien hay, como señalamos en el capitulo anterior, una convocatoria a que se conformen con el destino al que, por condición, parecerían estar destinados. Abordaremos esta cuestión con detenimiento en la parte final de la investigación.
} 
institución "menor infractor", pero ya no con el, también utilizado por la entidad, "joven de conducta problemática". Vinculan el primero de los significantes con la mácula estigmatizarte de la imputación del delito. Mientras expían su pecado por la infracción cometida (cumplimiento de la pena), dicen identificarse con la etiqueta "menor infractor", y desprenderse de esta marca infamante una vez hayan concluido el tratamiento. Respecto al segundo significante, "joven de conducta problemática", declaran no reconocerse en él, pues ahora "ya se portan bien"; no olvidemos que se saben inmersos en un proceso institucional de "mejora".en sintesis: el lugar que se les asigna los define socialmente. Están cumpliendo condena, por lo tanto son "infractores", pero están siendo recalificados, por lo que ya no son "problemáticos".

E: ¿Qué es lo primero que te viene a la cabeza cuando escuchas la expresión "menor infractor"?

Y: Un menor que ha robado.

E: ¿Y te identificas con ella?

Y: Sí... pues por lo que hice, ¿no? Por el robo que cometí.

E: ¿Cuánto hace que hiciste esa infracción?

Y: Un año.

E: Y después de un año, ¿te sigues considerando un "menor infractor"?

Y: Pues si porque todavia no termina mi tratamiento.

E: Entonces cuando termines tu tratamiento en la institución, ¿ya no te vas a identificar con la idea de "menor infractor"?

$Y$ : No

(Yoko, 16 años)

$E(a)$ : ¿Y te identificas con alguna de estas cuestiones ["menor infractor" y "joven de conducta problemática"]?

$E(b)$ : Con la primera.... porque, este, al principio sí me hubiera considerado problemático pero ahorita ya sería infractor por lo mismo de que me están dando los tratamientos y todo eso.

(Eric, 15 años) 
Si bien el rito de paso del tratamiento ${ }^{43}$ es entendido por los chavos como un tránsito que les conferirá un nuevo lugar en la institución, podemos referirnos a él también como rito de iniciación a un status deteriorado. El contacto de los chicos con el sistema de justicia en general, y con la institución en particular, nos remite en última instancia a un rito de degradación respecto al nuevo rol impuesto "menos infractor"-, cuestión que, como veremos en el próximo capítulo, suscitan en los jóvenes no pocas resistencias y tácticas para adecuar su conducta a las expectativas que sobre ellos se ciernen. Sabemos gracias a las inestimables contribuciones de Goffman (2003), que el ser calificado como desviado (en cualquiera de sus modalidades) tiene importantes consecuencias para la imagen que de sí mismo tiene la persona afectada. La consecuencia más importante es un cambio en la identidad pública del individuo, en el que los dispositivos de "reinserción", "prevención del delito", etc. contribuyen activamente al subrayar la condición socialmente inferior de quienes los transitan (de ahí la dimensión restaurativa del ritos de iniciación analizado -son arrojados a las siempre sospechosas "clases peligrosas"). Hemos visto como - rito de degradación respecto al nuevo rol impuesto -"menos infractor"-, cuestión que suscitan en los jóvenes no pocas resistencias y tácticas para adecuar su conducta a las expectativas que sobre ellos se ciernen. En palabras de Sack: "la sentencia crea una nueva cualidad en el acusado, lo sumerge en un status que él, si no existiera la sentencia, no poseería". (Citado en de Leo, 1985:64) El ingreso a la red de

\footnotetext{
${ }^{43}$ Podemos aventurarnos a situar tres etapas tomando en consideración los momentos propuestos por van Gennep (op.cit.), y el modelo elaborado por Vergara (2006:121-123) para el análisis de los ritos transicionales en Alcohólicos Anónimos. La primera es la toma de conciencia del mal (relacionada con la separación de van Gennep) en la que se fuerza al sujeto a elaborar una nueva autodefinición del ser, un ser que dice reconocerse asimismo errado, equivocado... un ser que reconoce su necesidad de corrección. El utillaje empleado por los profesionales para forzar la emergencia de esta "nueva conciencia" es, por una parte, el forzamiento a la autoinculpación a la que el chavo es sometido desde el primer contacto con la institución y, por otro, la recurrencia con la que los "operadores" instan a que los familiares pongan en escena, en presencia del joven, el sufrimiento y los padecimientos soportados a causa de la infracción cometida. La segunda fase, que hemos denominado de recalificación, trata de remodelarlos, de despojarlos de su "maldad" para dotarlos de nuevos "poderes" (autoestima y valores parecen ser los más poderosos) con los que puedan enfrentarse a los desafíos de la vida. Esta es sin duda uno de los espacios de mayor condensación simbólica para los chavos. Nos detendremos en ella en los próximos párrafos. El rito de paso de la reinserción culmina con la lo que la institución denomina y teatraliza "ceremonia de conclusión del tratamiento", donde profesionales, jóvenes y familiares se reúnen con pompa y boato para dar cuenta del trabajo de trituración y despojo al que los liminiodes fueron sometidos.
} 
justicia para menores atribuye una situación social específica, un rol, un nuevo estatus que supondrá una reformulación de su desviación, y que además, desarrolla consecuencias particulares sobre la personalidad de los individuos. Las marcas "menor infractor" y "joven en proceso de corrección" permean subjetivamente en sus portadores. La producción de los chavos como "problemáticos", modela sus prácticas de identificación. Sin embargo, aunque ponderamos el poder estigmatizador de la institución y constatamos la asunción de la nueva condición atribuida a los chicos, sostenemos que la propedéutica reformatoria no logra colonizarlos totalmente.

Lejos de presentar a un joven construido por y desde el poder (en este caso el de la red institucional), postulamos la capacidad de resistencia constante de los sujetos contra éste. He aquí uno de los postulados principales que incardina nuestra investigación. La mirada a nuestro objeto de estudio no puede reducirse a la omnipotencia panóptica del sometimiento. El poder no lo inunda todo. Siguiendo la tesis de Certeau (op.cit.:XLIV), autor fundamental en el desarrollo que sigue, existen procedimientos minúsculos y cotidianos, "maneras de hacer" por parte de los dominados "que juegan con los procedimientos mudos que organizan el orden sociopolítico". Lo que nos proponemos precisamente en el próximo apartado es exhumar las formas subrepticias que adquiere la creatividad táctica de los jóvenes atrapados en los circuitos institucionales de la "reinserción" y la "reeducación", para así acercarnos a los modos en los jóvenes habitan su tránsito institucional.

A estas consideraciones sobre la merma de la capacidad estigmatizadora, debemos añadir otras de orden logístico. Si bien la capacidad y disposición de resistencia de los sujetos es el fundamento nuclear que limita la omnipotencia de dominio subjetivo de la institución, el diseño del "tratamiento externo" permite acotar el alcance del marcaje social. Este tipo de MPA no contempla la asistencia diaria de los chicos a la institución (que en ningún caso excede las veinte horas por semana). Esta característica permite una dinámica de entrada y salida de la entidad, de tal suerte que los chavos pueden transitar por diferentes esferas y desempeñar diversos roles (familiar, escolar, institucional, grupo de pares, etc.). 
Consideración que nos conduce a sostener, como veremos a continuación, que los chavos se ven obligados a realizar ciertos ajustes en su papel cuando entran a la esfera institucional.

Entre bastidores, tecnologías mudas determinan y provocan el cortocircuito de las escenificaciones institucionales. MICHEL DE CERTEAU

El mundo es, en verdad, una boda. ERVING GOFFMAN

\section{II.b.2. Tácticas, resistencias y otras picarescas institucionales: comienza la función}

Los jóvenes oponen resistencia a los designios reformatorios de la institución. Hilan astucias, elaboran artimañas, tejen simulacros de adaptación que contrarrestan, aunque sin aplacarla del todo, la maquinaria de sometimiento institucional. Recorridos imprevisibles y en parte ilegibles que, aunque sujetos a sintaxis preescritas, "trazan argucias de otros intereses y deseos que no están determinados ni captados por los sistemas donde se desarrollan". (de Certeau, op.cit.:XLIX) "Maneras de hacer" a las que de Certeau denominó tácticas, "arte de los débiles" que responde a movimientos en el interior del campo de visión del enemigo, y que están dentro del espacio controlado por éste. Es decir, no cuentan con un lugar propio; no tienen más lugar que el del otro. Se trata de una lógica de acción acomodaticia, esto es, tiene como forma, no un discurso, sino una decisión misma, acto y manera de "aprovechar" la ocasión. En última instancia: maneras de hacer que dan cuenta del éxito del "débil" contra el más "fuerte" (op.cit.:43) y rehúsan la fatalidad del orden dominante.

En éstas los jóvenes trabajan con la economía cultural dominante y dentro de ella (op.cit.:XLIV), esto es, confeccionan sus tácticas a partir de los saberes elaborados con los elementos que recogen en su tránsito institucional de acuerdo 
con sus intereses y sus reglas propias. Recordemos que los chavos cuentan con una panorámica suficientemente clara y amplia de la "idiosincrasia" institucional para esta elaboración. Podríamos sintetizar los saberes "clave" en los siguientes términos:

a) Saben acerca de las intenciones recalcificadoras de la institución y su intento de "abrir nuestro cerebro y quitar todo lo malo".

"Pues nos ayudan a los jóvenes a cambiar las actitudes".

(Néstor, 18 años)

b) Conocen con precisión lo que los "operadores" esperan de ellos: un comportamiento adecuado que los certifique como "aptos" para la sociedad, así como su consentimiento a ser "tratados". Están al corriente de que el "éxito" de su tratamiento es medido por los profesionales a partir de la conducta observada y observable. Al ser interpelados en relación a lo que los profesionales esperan de ellos:

Y: (...) que vean tu comportamiento, ¿no?... que estás cambiando.

$E$ : ¿Y en qué crees que ellos [los profesionales] se dan cuenta de que has cambiado?

Y: Chale... en todo... en cómo les hablas, como te expresas, como caminas, como te vistes... (Yoko, 16 años)

"Lo que entiendo es cómo que me socialice con la gente... aprender a hablar como se debe en lugares, ¿no? El comportamiento..."

(Moisés, 18 años)

Pues yo creo que se demuestra sólo con la actitud, ¿no? Con la actitud, porque si vengo con esa actitud de "no hago nada", pues se van a dar cuenta.

(Jordi, 16 años)

c) Y lo que es más importante, saben que la decisión del juez para alargar la medida penal y continuar el tratamiento en la institución, o concederles la libertad definitiva depende de los informes emitidos por los profesionales de la institución 
sobre los "progresos" de su tratamiento. Ergo, exhibir su supuesta recalificación ante los "operadores" se vuelve una cuestión de primer orden.

En los párrafos que siguen se plantean algunas de las tesis principales sobre el modo en el que los jóvenes habitan la institución a partir del análisis de las tácticas que elaboran.

Una de estas artes, ya esbozada en líneas anteriores, nos remite a la constante negociación, adaptación y ajuste de la apariencia de los chavos en la esfera institucional. En términos goffmanianos, de su fachada socia/ ${ }^{44}$, a partir de la cual poder manipular las impresiones de los profesionales con el propósito de aparentar su adscripción a los intentos recalificadores del tratamiento. El hecho de que la MPA permita a los jóvenes circular por otras esferas sociales (familiar, laboral, escolar, institucional, etc.), los impele a una orientación continua de esta fachada, dependiendo del escenario por el que transiten. ${ }^{45}$ (Asimismo, y como apuntábamos en el apartado anterior, esta suerte de "movilidad" merma los efectos estigmatizadores inherentes al paso por entidades "correctoras"). El concepto de ajuste situacional de F. Moore (1978:39-40) nos permite precisar uno de los principales modos de habitar la institución por parte de los chavos. Nos referimos a tácticas de ajuste al nuevo escenario, y a sus reglas, con el propósito de aplacar las ambigüedades, incertezas e indeterminaciones propias de toda interacción social. Éstas tratan de regular y/o sortear la fricción resultante entre los imperativos institucionales (vinculados al cumplimiento de la pena), y el forzamiento al que son sometidos los jóvenes para acatarlos.

La investigación nos muestra que estos ajustes situacionales vienen dados en términos dramatúrgicos; de ahí se desprende nuestra segunda tesis. A saber: los jóvenes, ante la asignación de etiquetas denigratorias e intentos de "trepanación",

\footnotetext{
${ }^{44}$ Definida por el autor como dotación expresiva de tipo corriente empleada por el individuo durante su actuación. (2004b:34)

${ }^{45}$ Con el propósito de contrastar el modo en el que se desenvuelven los chavos en otras esferas sociales, mantuvimos conversaciones informales con los familiares sobre cómo los percibian en otros entornos (hogar, escuela o grupo de amigos...). Sus respuestas nos devolvieron descripciones alejadas de las marcas "problemático", "infractor"...
} 
urden una trama de ardides, estratagemas y astucias -indisociables del poder y sus asimetrías- que les permiten subvertir las prácticas de abyección de las que son objeto, así como resistir a los efectos del estigma. Una de sus principales operaciones de respuesta para eludir la "profanación del yo" (Goffman, 2004a), reside en la interpretación dramática del papel que de ellos se espera. La actuación de los chavos gravita en torno a un aparente consentimiento a la intervención "psico-pedagógica-educativa" de los profesionales, y a una representación teatral de los supuestos éxitos del tratamiento operados en ellos. Podríamos decir que el papel a interpretar es el de "menor-infractorcomprometido-con-su-proceso-de-remodelación". Debemos volver a subrayar en este punto que, de una correcta interpretación, depende la obtención de una de las cuestiones capitales para ellos: informes institucionales favorables para conseguir la libertad definitiva. ${ }^{46}$

La Escuela de Chicago describió las relaciones sociales como tramas de mediaciones simbólicas recíprocas en las que los individuos despliegan sus recursos para salvaguardar su imagen, y las que, como nos recuerda Delgado (op.cit.:106), nunca son ajenas a los determinantes de dominación y jerarquía. ${ }^{47}$ Sabemos por la metáfora teatral goffmaniana que las artes básicas en la vida social son las del manejo de la impresión, esto es, aquellas que permiten al individuo ejercer un control estratégico sobre su propia imagen. (2004b:151-152) La fachada, con sus indispensables estratagemas y subterfugios, es parte de la interacción social; su construcción permite al sujeto manejarse a sí mismo en su

\footnotetext{
${ }^{46}$ Lemert (op.cit.:48) ya apuntó las resistencias del sujeto al intento de asignación del estatus desviado, matizando que los sujetos estigmatizados pueden asimismo encontrar determinadas ventajas en su asunción.

47 Los dispositivos interrelacionales observados durante la exploración etnográfica entre los operadores y los chavos-familiares dan cuenta de interacciones no simétricas entre los actores como consecuencia de la atribución de un estigma, y de las relaciones de poder que subyacen en la potestad de inferiorizar al otro. Observamos en no pocas ocasiones, actitudes intransigentes, incluso agresivas, invasoras, atropelladoras, infantilizadoras y culpabilizadoras de los "operadores" con sus interlocutores. Especialmente en las entrevistas individuales de los profesionales con los familiares destinadas a la elaboración del diagnóstico. Durante las mismas fueron habituales las insidiosas convocatorias a que los padres se autoincluparan por la "mala" educación proporcionada a sus hijos, y por ende, a que reconocieran su culpabilidad en el delito cometido por sus hijos. Los familiares son interpelados en más de una ocasión con preguntas del tipo: "¿En que colaboró usted para que su hijo cometiera el delito?".
} 
relación con los otros, y con su entorno, y comportarse adecuadamente en las diferentes y variopintas situaciones sociales. Esto es precisamente lo que los chavos despliegan en el marco institucional: manipulan las impresiones, construyen apariencias y apreciaciones que den pie a la construcción de su fachada a partir de los comportamientos observados, por los cuales los individuos "esperan ser tomados no por lo que son, sino por lo que parecen, o mejor, por lo que pretenden parecer". (Delgado, op.cit.:72) De esta manera, los chicos exhiben sus desgracias, tratan de enternecer con la mirada, hacen creer, esbozan compromisos, llaman la atención sobre su desamparo, ponen cara de no saber nada, usan su supuesta fragilidad... todo un despliegue del utillaje dramatúrgico para contrarrestar los mecanismos de degradación, reducción y redefinición llevados a cabo por la institución.

Goffman (2004a) sostuvo en una de las más importantes contribuciones al estudio de las instituciones totales, que éstas, además de provocar en el interno un proceso de degradación y de desestructuración subjetiva, generan mecanismos de adaptación, roles y expectativas de importantes consecuencias para los sujetos. Aunque no podemos referirnos estrictamente a la entidad estudiada como institución total, parte del planteamiento goffmaniano sobre las modalidades estratégicas de adaptación son válidas para nuestro trabajo. El autor de "Internados" constata tres tipos de respuesta: la oposición a ultranza, la sumisión y el acatamiento aparente. Esta última da cuenta de la táctica de resistencia de los chavos a la intervención institucional, encarnando el rol de "interno" dócil. Con esto no queremos decir que no se produzcan fricciones con los profesionales, desafíos a las reglas, sanciones, partes, deslices, etc. por parte de los chavos. ${ }^{48}$ Sostenemos que este tipo de incorrecciones conductuales momentáneas son parte del "juego", esto es, se adecuan al comportamiento que los "operadores" esperan de un "menor infractor". Si bien exhibir su docilidad es importante, mostrar

\footnotetext{
${ }^{48}$ En las actividades grupales es frecuente que los chavos trasgredan las reglas marcadas para esos espacios: no mascar chicle, entrar con aretes, exhibir tatuajes, no sentarse correctamente... Estas sesiones estuvieron atravesadas por llamadas al orden constantes por parte de los "operadores".
} 
su "asocialidad" también lo es. Recordemos que el interaccionismo simbólico parte de la premisa de acuerdo con la cual la interacción se fundamenta en la obligación de los participantes de hacerse mutuamente accesibles y resultar mutuamente previsibles. Bajo esta mirada nos referimos a la interacción social como la puesta en escena de un papel asentado en la comunicación recíproca y la asunción de ciertas reglas: Ios chavos deben actuar bajo el guión establecido. ${ }^{49}$ Asimismo, esta corriente sociológica subraya la importancia de definir adecuadamente cada situación, lo que significa, sintetizado por Gallén (op.cit.:71), establecer los límites del comportamiento adecuado, el marco que distingue un episodio que se inicia, identificar a los que intervienen y sus papeles respectivos, asumir cooperativamente una determinada estructura previa de expectativas y valores considerados pertinentes y adecuados. Así lo muestra la exploración etnográfica; los encuentros "mixtos" (profesionales, chicos, familiares, incluso la presencia intrusa de la investigadora) estuvieron atravesados por la correcta interpretación de los roles que debía jugar cada quien. Los participantes de la escena actuaron siempre bajo las expectativas normativas que se cernían en torno a cada uno de ellos: los "operadores" como instigadores de la moral (utilizando un termino del viejo Becker), y los chavos como pigmaliones que se están dejando modelar. Un sofisticado montaje urdido de frases estereotipadas, preguntas retóricas, vocabularios específicos, pero también de miradas, gestos, actitudes, movimientos, en donde los sujetos quedan convocados a ocupar determinados lugares y encarnar ciertos papeles.

Una de las tácticas que los chicos utilizan de forma recurrente para salvaguardar su representación ( $\mathrm{y}$ con ello rehuir el dominio institucional), consiste en la apropiación del discurso de la entidad y de sus significantes estrella, utilizándolo a

\footnotetext{
${ }^{49}$ Esta consideración es extensible a familiares y profesionales. Sin embargo, acotamos nuestro análisis a las actuaciones de los chavos.

${ }^{50}$ En encuentro cara a cara entre normales y estigmatizados es para Goffman (2003:25) una de las escenas primordiales de la sociología, pues son los momentos en que ambas partes deberán enfrentar directamente las causas y los efectos del estigma; revelen la tensión que engendran las relaciones sociales. La incertidumbre que reina en el encuentro observador-observado, humilladorhumillado, estigmatizador-estigmatizado se refiere a la traducción de la identidad que le es atribuida al otro.
} 
su favor. Constatamos una eficiente puesta en escena discursiva de los jóvenes (y también de los familiares obligados a tomar el tratamiento). Su discurso es un fiel eco de la soflama institucional, acompañado de una relación proporcional entre el tiempo transcurrido en la entidad y el manejo del discurso: a más tiempo, más fiel es el eco. De esta manera, los chavos dicen, investidos de solemnidad, necesitar trabajar su "autoestima", evitar ponerse en "situaciones de riesgo" o requerir más "comunicación" con sus papás. Al mismo tiempo sostienen al unísono que la familia y la colonia de procedencia son las causas principales que los condujeron al delito. Sus dotes dramatúrgicas alcanzan la máxima expresión cuando se refieren a lo "malos" que eran antes y lo "buenos" que están aprendiendo a ser ahora gracias a los "tratamientos". Ya Malinowski (1973 [1922]) advirtió décadas atrás sobre las tensiones existentes entre las declaraciones normativas de los actores sociales y sus acciones reales. En la misma línea, Lévi-Strauss (1971) sostuvo que lo que los interesados creen, está siempre muy lejos de lo que hacen o piensan efectivamente. En todo caso advertimos que, desde el punto de vista dramático, son actuantes disciplinados (Goffman, 2004b:231), esto es, recuerdan su parte y no hacen gestos inesperados ni dan pasos en falso durante su actuación. Es necesario que la realización dramática de la actuación logre ser significante para los "operadores" (y la investigadora). Esta puesta en escena debe expresar durante la interacción el mensaje deseado, que tiene que ser inequívoco: estoy aprendiendo en la institución a ser un buen chico; me estoy reinsertando.

\section{E: ¿Qué has aprendido en reintegra?}

A: Pues educación... cívica. A hacer, este, como te diré... antes así como que yo era bien grosero con la gente $y$ ahora quiero aprender cómo que no... antes como que buscaba muchos problemas con los actos, con la mirada que haces, y ya pues haciendo asi consigo algo, más amigos, mis familiares...

(Adrián, 18 años)

Y: Pues yo digo que si me sirve porque también viene mi familia con mi terapeuta. Y visto en todo el tiempo que llevo acá, ahorita ya convivo más con mi familia; ya no peleamos, ya no llevamos mejor. Ya estamos más unidos.

(Yoko, 16 años) 
Si tomáramos en conjunto la totalidad de las entrevistas realizadas a los chicos, podríamos elaborar una suerte de "Recetario para una buena recalificación moral". $Y$ es que en todas y cada una de ellas aparecieron repetidamente los ingredientes necesarios para ser un "buen chico": Valorar a mi familia; Pedir permiso para salir; Comunicarme con mis papas; No juntarme con mis perniciosas y antiguas amistades; No andar en la calle (pues no sabes a lo que te expones, es un lugar de "riesgo"); Valorar más lo que se tiene; Pensar las cosas dos veces antes de hacerlas.

Otra de las repeticiones recurrentes en las entrevistas podría ser sintetizada de la siguiente manera: "al principio no me gustaba venir a la institución, pero ahora [asombrosamente] sí me gusta y, además, me está sirviendo de mucho".

A: Eso es, tenía la obligación de venir. Es lo que a mí al principio me parecía. Y luego me empezaron a gustar las pláticas, el trato que me dan y fui cambiando.

E: ¿En qué fuiste cambiando?

A: En todo... en mi forma de ser, en mi carácter, en mi propósito en la vida...

(Adrián, 18 años)

Sin embargo, a pesar de que recogimos esta afirmación en numerosas ocasiones durante el trabajo de campo, una vez más los decires no concuerdan con los haceres. Una de las principales batallas de los "operadores" con los jóvenes, además de la insidiosa corrección conductual, es la continua falta de asistencia a las sesiones tanto grupales como individuales. Los chavos son intermitentes en sus ausencias y sus presencias. Saben que a la tercera falta la institución da parte al juzgado para que revoquen la libertad asistida. Constatamos durante el trabajo de campo una fina tensión en este aspecto. Los chavos dejan de asistir a las citas con la justa frecuencia (no más de tres veces seguidas) para no motivar un aviso al juez de menores. Se ausentan unas semanas, vuelven a venir presentando 
excusas recurrentes (entre las más socorridas: "tengo a mi mama enferma"), para después volver a ausentarse. ${ }^{51}$

Otra táctica de resistencia que pudimos constatar para sortear situaciones incómodas, practicas de infantilización o injerencias en su intimidad consideradas excesivas consiste en el mutismo y el asentimiento ("Les doy el avión”), o simplemente la risa, es decir, tomarse a guasa lo que le están diciendo, claro, siempre con discreción. Todas ellas necesitan un alto grado de astucia dramática.

"Pues controlando mis emociones, ¿no? Que no me vean el enojo, la impotencia de no poder hacer nada. (...) A veces es sobrellevarla... que lo que digan no me afecte, para no dar una mala contestación".

(Jordi, 16 años)

Concluimos estas líneas subrayando una de nuestras conclusiones principales: si bien estos jóvenes marcados con el atributo de "problemáticos", "delincuentes", "infractores", etc., han acabado aprendiendo e interiorizando los términos de su inferioridad, la propedéutica correctora de la institución no ha logrado colonizarlos del todo. El trabajo de campo revela que a pesar de las identificaciones con las etiquetas institucionales, ellos se autoperciben también como chavos trabajadores, responsables, con intereses y metas, como "alguien que quiere ser algo en la vida". Sabemos que el hecho de recibir del otro una identidad supone la adjudicación de un lugar concreto en lo social. (Berger y Luckmann, op.cit.) Toda etiqueta nos remite a una cierta localización. Los chicos saben acerca de la nueva identidad deteriorada que comenzaron a aprender meses antes de la entrada en la institución, cuando fueron detenidos y confinados durante meses en el Consejo de Menores. Sin embargo, no están inermes, ni mucho menos permanecen indiferentes ante los intentos de asignación de su nuevo estatus. Despliegan maneras de hacer que les permitan subvertir los efectos subjetivos de la etiqueta; tácticas que engañan al orden dominante y rehúsan su "condición de ley, de

${ }^{51}$ Las inasistencias se van sumando de tal manera que trascurrido el año máximo de pena, éste se alargará hasta recuperar los días "perdidos". Los profesionales reconocieron que en la mayoría de los casos la duración de las penas exceden los 12 meses. 
sentido y de fatalidad" (de Certeau, op.cit.:32). Argucias que nos remiten a prácticas de subjetivación (Duschatzky y Corea, op.cit.;20), esto es, recursos que permiten a estos jóvenes sortear las prácticas denigratorias. La construcción de una fachada social ajustada a las expectativas de su nueva condición y la interpretación del papel del "joven delincuente en proceso de corrección" son un arma imprescindible de resistencia a la abyección.

\section{II.b.3. Cartografías de subjetivación: la palabra como anclaje}

Marco Polo instaba al Gran Kan a discernir lo que es infierno de lo que no.

Si bien esta investigación ha cuestionado de forma medular las dinámicas de "dessocialización" que atraviesan gran parte de la práctica del campo social, tratando de develar sus "metamorfosis y disfraces", es necesario señalar que no todo, en nuestro recorrido etnográfico, ha sido infierno. A pesar de los intentos reformatorios y recalificadores de la institución, existen espacios, por minúsculos que sean, que permiten la emergencia de los chavos en tanto sujetos. Asimismo no podemos olvidar que la institución brinda un servicio jurídico que procura la aplicación de MPA evitando algo mucho más terrible que el sometimiento a las ortopedias morales del tratamiento en externación. A saber: el cumplimiento de la pena en un correccional. ${ }^{52}$

Los chicos encuentran en la institución pequeños deltas; puntos donde anclarse para no ser arrastrados del todo por las corrientes de licuefacción que horadan nuestro tiempo. En este sentido, tal vez haya que pensar, como sostienen Duschatzky y Corea (op.cit.:74), que en ausencia de referentes a los que sujetarse, lo propio es que cualquier sistema de referencias que se arme conlleve a la oportunidad de un proceso subjetivante. La investigación muestra la existencia de espacios donde es posible la producción de operaciones de subjetivación, esto

\footnotetext{
${ }^{52}$ Claro que los casos atendidos por la institución son escrupulosamente elegidos. Sólo brindan asesoría legal a aquellos jóvenes que "sean primodelincuentes", y que, por la tipología del delito, tengan altas posibilidades de que les sea aplicada una MPA. En la consecución de este tipo de sentencias les va la vida. Planteado en términos simples: si no hay MPA, no hay institución.
} 
es, la emergencia del sujeto, no como una tabula rasa sobre la que operar, sino como un sujeto con capacidad de elección y deseo.

Indagar y ponderar estos lugares nos parece una tarea crucial para el propósito de esta investigación. La pregunta por los modos de producción social de los sujetos en particulares circunstancias, es también la pregunta por la eficacia de los dispositivos de trabajo social educativo. En este punto antropología y pedagogía social se intersectan. A través del análisis etnográfico de los tránsitos institucionales podemos abrir interrogantes acerca de qué modelo de trabajo educativo puede albergar a los jóvenes en tanto sujetos, acogiendo sus intereses y suscitando nuevos deseos que les inciten a emprender viajes altamente valorados, y a apropiarse de los artilugios culturales trasmitidos a tal efecto.

Los lugares institucionales donde se observa la emergencia del sujeto, están mediados por la palabra y el saber, ambas, cuestiones que atraviesan la práctica pedagógica. Se trata de dos espacios grupales. El primero es el grupo psicopedagógico-educativo de "desarrollo humano", y el segundo, el lugar donde los chavos toman clases de apoyo para obtener el certificado de secundaria guiados por voluntarios de INEA (aunque no se trate de un espacio propiamente institucional, como ya apuntamos en la presentación de la entidad).

El grupo de "desarrollo humano", consta de dos momentos. En el primero, que podríamos calificar de pedagógico ${ }^{53}$, los "operadores" abordan uno de los diferentes módulos temáticos que conforman el curriculum de la actividad (adicciones, autoestima ${ }^{54}$, sexualidad, realidad social, valores, comunicación y

\footnotetext{
${ }^{53}$ Es importante puntualizar que la educación no es concebida es su dimensión socializante, esto es, en el sentido de acción orientada a la incorporación de los sujetos a la cultura de su época, sino en su función de recalificación moral. Más preocupada en la "domesticación" de los chicos, que la trasmisión del patrimonio cultural que amplíe sus posibilidades de nuevas filiaciones con la trama social y cultural de su tiempo.

${ }^{54}$ La tan mentada autoestima, en educación, no es sino la verdadera estima que, en términos de confianza, de apuesta al por-venir, los educadores sean capaces de transmitir a los sujetos. Se trata de posibilitar su acceso, en carácter de herederos legítimos, a los patrimonios culturales que les pertenecen, en sentido estricto. Para ello hay que poner en juego la confianza: confianza en que harán buen uso de ese legado, esto es, que acrecentarán la herencia, cambiándola, actualizándola. (Núñez, 2003)
} 
violencia familiar), para después comentar y discutir los contenidos con los jóvenes.

Más allá de "distorsiones" como (a) los frecuentes cuestionamientos de la palabra de los chavos por parte de los "operadores"; (b) las dinámicas inquisitoriales donde la insistencia en la disciplina parecería inundarlo todo, o casi todo; y (c) que los contenidos a trasmitir no son precisamente de valor social, los chavos, cuando se apropian del espacio (coincidiendo con una intervención más discreta de los profesionales), consiguen dar sus opiniones, generar debates sobre algunos de los aspectos abordados, hablar de sus experiencias cotidianas, intercambiar inquietudes, escuchar y ser escuchado, etc. En la segunda mitad del grupo de "desarrollo humano", los profesionales tratan de abrir un espacio donde los chavos compartan los aconteceres más relevantes de la semana. Todos los miembros del grupo están obligados a contestar la pregunta protocolaria: ¿Cómo te sientes? ¿Hay algo que quieras compartir con el grupo? A pesar de que observamos "salidas por la tangente", respuestas estereotipadas, preocupaciones recurrentes acerca de la salud de las abuelas, y otras argucias y escamoteos, constatamos momentos en los que los chavos llegan a compartir preocupaciones e inquietudes que no parecen fútiles. Éstas encuentran eco con otros miembros del grupo, que manifiestan sus enfoques y sentires sobre las palabras de su compañero. $Y$ es que la palabra pacifica y estructura.

E: ¿Por qué dices que el grupo te ayuda a no pelearte?

Y: Pues sí, porque como estamos acá estamos platicando... Platicamos lo que nos pasa en la vida. (Yoko, 16 años)

Y ya empecé a platicar y todo... y es lo que más me gusta, me puedo expresar yo mismo. (Eric, 15 años)

Lo que más [me gusta de la institución]... que hablen conmigo, tener una conversación, eso es lo que me gusta.

(Adrián, 18 años)

También atravesado por el encuentro de la palabra y el saber, el espacio 
(informal) académico ofrecido por INEA deviene lugar de anclaje. Los jóvenes que acuden al aula son convocados por los profesores voluntarios a ocupar una plaza como estudiantes. Trabajan sus libros de ejercicios: resuelven problemas matemáticos, plantean dudas sobre la simetría de un poliedro, se ensimisman con la sintaxis de una oración...

"Y si me gusta venir aquí [a la institución] ... bueno aquí no mucho, pero si me gusta venir a INEA". (Yoko, 16 años)

Ambos espacios, grupo de "desarrollo humano" e "INEA", aparecen de forma unánime en sus apreciaciones como los más estimados. ¿Por qué tomar estos enunciados como estatuto de "verdad", y otros como estrofas de un guión dramatizado? Sin perder de vista que se trata de actores altamente competentes, es pertinente señalar que durante los encuentros con los chavos hubo momentos (pocos) en los que el uso del instrumental dramático no fue tan recurrente. El trabajo de campo vino atravesado por el intento incesante de abrir espacios de interacción "informales" con los jóvenes, donde poder explorar los intersticios de lo que, en un primer acercamiento, era un discurso hermético y colonizado por los significantes institucionales. La inercia panóptica de los "operadores" y los escasos cuatro meses de presencia continuada en la institución no fueron buenos aliados, sin embargo permitieron una cierta aproximación al pensar de los chavos. Si bien los primeros espacios de interacción "formal" (cubículo, investigadora, joven y grabadora) estuvieron atravesados por respuestas estereotipadas, la búsqueda de espacios "informales" (recesos entre actividades, paseos al metro de regreso a casa...), permitieron la emergencia de respuestas que suponemos menos "actuadas". A partir de ellas, hemos podido contrastar, disentir, disputar la retórica institucional de los chicos, pero sobretodo, hemos podido construir un saber a cerca de lo que desean. De esta manera sostenemos que los espacios descritos, son lugares que les permiten un cierto anclaje.

Siguiendo el sentido que Duschatzky y Corea (op.cit.) confieren a las prácticas de subjetividad constatamos, además de los espacios que posibilitan un anclaje para 
el sujeto, otras operaciones donde emerge el sujeto para habitar situaciones de inferiorización y menosprecio. Las modalidades de resistencia y las tácticas abordadas en el subcapítulo anterior suponen la primera coordenada en el relieve de estas prácticas de subjetivación. Sin detenernos en ellas, pues ya han sido abordadas con detenimiento, dirigiremos la mirada a aquellas respuestas en la que los chavos nos recuerdan que, lejos de ser "objetos" a corregir, son sujetos con capacidad de elección, decisión y deseo.

"Ellos [los profesionales] nos lo dan [el tratamiento] y tu lo agarras o no lo agarras. No te pueden obligar a tomarlo".

(Jordi, 16 años)

E: Entonces, ¿son ellos [los profesionales] los que te dicen que tienes que hacer "el bien"? A: Sí, pero ya es decisión mía si lo tomo o lo dejo.

(Adrián, 18 años)

En esta línea, es interesante recoger las enérgicas reacciones al ser interrogados a cerca de su opinión sobre las visiones miserabilistas y conmiserativas de la delincuencia juvenil. Ante las retóricas de humillación que subyacen en concepciones victimistas, algo del orden de la elección se pone en juego.

E: ¿Qué te parecen las opiniones de algunas personas que ven a los chavos que han delinquido como victimas, es decir, que cometieron un delito por pertenecer a una colonia pobre, o por tener una familia "desestructurada"?

A: Que está mal, porque el chavo sabe lo que hace, el chavo no es un niño de cinco años, ya sabe lo que es el bien y lo que es el mal. Él decide si hacer un delito, o no. Pero está mal juzgarlo porque asi le das más ánimos y saliendo [del Consejo de Menores] yo pienso que va a ser igual y por eso hay mucha delincuencia, por lo mismo. Es lo que pienso. Es tu decisión si vas a tomar el bien o vas a tomar el mal. Es tu decisión... si vas a tomar el mal tienes que atenerte a las consecuencias después.

(Adrián, 18 años)

De la misma manera se alejan de aquellas afirmaciones que auguran una ausencia de futuro para ellos. Al ser interpelados en este punto, las respuestas 
fueron contundentes: "depende de las decisiones que uno tome". A lo que hay que añadir que la mayoría de ellos se imaginan con un "buen" porvenir, y que, a pesar de la insistencia de los profesionales de verlos como sujetos sin entusiasmos y "sinsentido", ellos hablan de sus intereses y proyectos ("sacar adelante a mi familia", "vivir a parte de mis papas", "aprender más de mecánica y si es posible poner mi propio taller", "hacer la carrera militar", "terminar mi secundaria", "me veo trabajando en varios antros como DJ (...) no voy a descansar hasta llegar a eso"...).

Concluimos este recorrido con una última parada: el intento de desmarque de los jóvenes del estigma "menor infractor". Al plantear el interrogante “¿Cómo crees que te ve la gente?", las respuestas dan cuenta del alcance que esta mácula comporta.

"Se te quedan mirando como si fueras de otro mundo".

(Manuel, 15 años)

"Hay gente que ve un chavo de nosotros, y así como que se espanta" (...) Como un ratero, como un adicto, un, este, alguien que piensa que no vales nada".

(Eric, 15 años)

Aún en condiciones en las que los dispositivos de etiquetamiento implementan una importante función de deterioro del estatus, se registran operaciones de sujetivación que les permiten desvincularse de máculas abyectas. Como arguye Becker (op. cit.), los estigmatizados buscan otros procesos de clasificación, de tal manera que los chavos se autoperceiben como personas "normales", "tranquilos"..., teniendo muy presente, eso sí, la marca infamante que les acompaña por la colonia de procedencia, la entrada al circuito de justicia juvenil, etc. Muchos de ellos coinciden en señalar que, en última instancia lo importante es la concepción que "tengas de ti mismo", más allá de la etiqueta adjudicada por el resto. 
"Y luego yo pienso pues que digan lo que quieran, lo importante no es cómo te ves, sino como eres".

(Eric, 15 años)

"Se me quedan viendo las personas como diciendo "ratero". Con la mirada te dicen todo, pero no es cierto. Mientras que sepa yo que no hago nada, todo está bien".

(Adrián, 18 años) 


\section{CAPÍTULO III}

\section{EL TRABAJO SOCIAL EDUCATIVO COMO ANTI-DESTINO}

Lo que más falta nos hace es creer en el mundo, así como suscitar acontecimientos que, aunque sean mínimos, escapen al control; hacer nuevos espaciotiempos, aunque su superficie o su volumen sean reducidos... la capacidad de resistencia o, al contrario, la sumisión a un control, se deciden en el curso de cada tentativa.

GILLES DELUZE

El recorrido final de este trabajo pretende ser una aportación más, al esfuerzo de aquellos profesionales del campo social que, con su labor cotidiana, contribuyen a saldar la deuda de vida que los adultos contraemos con los nuevos. Una deuda simbólica que, recordando a Arendt (1996), nos remite a la responsabilidad de posibilitar el acceso de las nuevas generaciones al mundo, esto es, al encargo de ofrecer a nuestras infancias y adolescencias lugares valiosos y herramientas para ocuparlos. Tarea especialmente preciada (e indispensable) en el trabajo de atención a jóvenes que, bajo el empuje de la corriente de un capitalismo salvaje, son encauzados a ocupar los lugares destinados al resto social. Esta investigación a tratado de vislumbrar cómo ciertas prácticas del campo social, inscritas en la lógica de la gestión diferencial de determinadas poblaciones, coadyuvan en la producción y estancamiento de los "excluidos sociales", de aquellos jóvenes considerados superfluos (Bauman, 2004) e prescindibles (Forrester, op.cit.) para los engranajes de la maquinaria neoliberal.

¿Qué otros lugares permiten a los chavos emprender recorridos inéditos que los alejen del determinismo de un supuesto destino prefijado? ¿Qué herramientas son necesarias trasmitir para que puedan construir nuevas articulaciones con el mundo? ¿Qué modelos de trabajo educativo nos permiten alejarnos de las intervenciones que sólo confirmar la privación y la impotencia? 
Antes de adentrarnos en la construcción de las posibles respuestas a estos interrogantes, consideramos oportuno aclarar dos cuestiones. En primer lugar, matizamos que el modelo institucional por el que apostamos no está concebido especialmente para aquellos tipificados por la ley como "menores infractores". Sabemos que el trabajo sólo sobre los jóvenes "desviados", significa reforzar su pertenencia a una condición separada y diferente, con los riesgos de convertir ese estatus en resorte para un destino de resto social a segregar. Creemos que es necesario trabajar desde instituciones no separadas y no especiales para "delincuentes", sino desde lugares abiertos y franqueables para todos los jóvenes; espacios que puedan albergar a todas las adolescencias. En segundo lugar, deseamos puntualizar que la propuesta aquí presentada no responde a un cuestionamiento de la institución estudiada en términos de éxito o fracaso de su tarea "resocializadora". Plantearlo en esos términos supondría implícitamente una adhesión a los objetivos "reeducadores", al mismo tiempo que un reconocimiento de la validez general del tipo de procedimientos para alcanzarlos. Nuestra posición es mucho más radical (en el sentido de apuntar a la raíz, a lo fundamental): impugna de forma integral las prácticas higienistas en términos ideológicos, políticos y éticos. Matizadas estas cuestiones, pasemos a lo que verdaderamente nos concierne en este capítulo final: dejar espacio y hacer durar lo que no es infierno.

La aproximación etnográfica nos ha permitido constatar que los espacios que ofrecen la posibilidad de albergar la subjetividad de los chavos están atravesados por dos elementos entroncados en la práctica educativa: el saber y la palabra. Esta constatación supone el punto de partida en el camino exploratorio hacia nuevos marcos institucionales que posibiliten la creación y consolidación de dispositivos de trabajo educativo que, alejándose de la propuesta neoliberal de control disciplinario, posibiliten la apertura de canales que conecten a los jóvenes con esferas sociales y culturales inéditas. Se trata, afinando más nuestra propuesta, de un lugar para la educación social, esto es, para la acción social 
orientada a la incorporación de los sujetos al entramado de su época a través de la trasmisión de las herencias culturales que, por derecho, corresponden a todo ser humano. (Núñez, 1999) El trabajo social educativo transmite a los jóvenes las llaves de acceso a particulares y valiosas vinculaciones sociales. La educación, en tanto que posibilitadora de recorridos impredecibles, nos aleja de los lugares que convocan a la determinación y lo definitivo. Examina situaciones de imposibilidad contingente y trabaja con todos los medios para transformarla, creando las condiciones para que algo de otro orden pueda nacer (Duschatzky y Corea, op.cit.), para que el sujeto pueda habitar un por-venir, trazar sus propios recorridos, y disponer de nuevos tiempos y lugares. La educación social es, utilizando la metáfora de Núñez (2005), como un anti-destino... que "permite a los sujetos 'ponerse en camino', partir de un lugar a otros, cuyas arquitecturas, alcances y toponimias desconocemos de antemano. La educación, la educación social, nos impulsa en los tránsitos o trayectorias vitales, en la medida que nos provee no sólo de los artilugios simbólicos necesarios para la circulación social y las difíciles relaciones con los otros, sino de la confianza para realizar dichos trayectos, para intentarlo".

Para ponerle viento a estas velas hay que rehuir de la idea de lo irreversible y lo conclusivo; de diagnósticos que arrojan sentencias implacables sostenidas en la alucinación positivista de que es posible acceder al "interior" del otro y forzarlo a cambiar su subjetividad. En necesario alejarse de prácticas que recurran a etiquetas inmovilizadoras, que terminan obturando toda posibilidad de emprender otras búsquedas. En un lugar distinto (y distante) a las profecías de ignominia, el trabajo social educativo que disiente del quehacer neohigienista, se abre a la incertidumbre, al descubrimiento y a lo inédito del encuentro con el otro, rasgos constitutivos de la ética educativa. El otro no es un ser predecible, no tiene una naturaleza desviada, ni unas propiedades intrínsecamente anormales. El otro es un enigma, un interrogante, y los profesionales del campo social deben estar dispuestos a admitir y sostener la incógnita que éste representa. 
Se trata de construir modos de trabajo que se sostengan en lo imprevisible, y que al mismo tiempo, mantengan la apuesta esencial de toda tarea educativa. A saber: el envite por que los chicos urdan nuevas filiaciones sociales y culturales. Apuesta en la que subyace la convicción de que estos jóvenes serán capaces de ocupar otros lugares; que podrán apropiarse de los recursos culturales que los profesionales de la educación les trasmitan, y que con ellos podrán emprender recorridos inéditos, particulares e insospechados.

Nos topamos aquí con otra de las piedras de toque de la tarea educativa: la trasmisión de contenidos culturales. Estos artilugios simbólicos de orden cultural representan no sólo el utillaje con el que el sujeto podrá emprender otras búsquedas y enfrentarse a nuevos desafíos, suponen también el resorte que puede provocar, suscitar, estimular, movilizar sus intereses. La transmisión pone a disposición de los sujetos el instrumental necesario para circular por lo social amplio, ofreciendo a quien lo recibe un "espacio de libertad". (Duschatzky y Corea, op.cit.:93) Apostamos entonces por un modelo institucional atravesado por aquellos contenidos culturales necesarios para el acceso y circulación por el entramado social de época. Contenidos, por lo tanto, de valor social que serán traspasados por los profesionales de la educación proponiendo su uso y apropiación. $^{55}$

Es en el marco de estas consideraciones que cuestionamos la importancia y el valor de la transmisión del inventario catequizador como llave efectiva de acceso a nuevas y apreciadas filiaciones. La trasmisión, o más correctamente, la inculcación de valores, habilidades sociales, competencias, entre otros artefactos, responden más al intento de moralización y domesticación de estilos de vida, que a la apuesta por habilitar las posibilidades de otros por-venires. Es más, este tipo de contenidos terminan provocando el tedio y el hastío que obturan los lugares

\footnotetext{
55 Núñez y Planas (1997) realizan una proposición de cinco áreas referenciales para la estructuración de los contenidos que podemos tomar como propuesta: 1) Área de lenguaje y comunicación; 2) Área de sujeto social y entorno; 3) Área de arte y cultura; 4) Área de tecnología; y 5) Área de juego y deporte.
} 
para que algo del orden del consentimiento a la acción educativa y del interés de los chavos pueda emerger.

Es pertinente volver a recordar en este punto que el objetivo de la acción educativa no es el cambio del "interior" del sujeto. Nuestro planteamiento parte de otro lugar: es el trabajo educativo el que produce efectos de cambio en el sujeto; de donde será necesario diferenciar, como nos recuerda Núñez (1990), efectos y función. La función de la educación es la transmisión, no el cambio de estructura ("interna", "moral", "inconsciente"...) del sujeto. Aclaremos aquí para una mejor exposición de la idea, que el sujeto de la educación es un sujeto dividido. Las contribuciones de Kant y Lacan nos permiten hablar de esta división en una dimensión social -la manera en que éste se representa o posiciona en lo socialesto es, su sociabilidad, y una dimensión de orden particular, su subjetividad. Entendemos que el trabajo educativo debe realizarse en el plano, no de la subjetividad, sino de la sociabilidad, asumiendo, como decíamos, que este trabajo tiene efectos estructurantes en aquella. ${ }^{56}$ (Thomas y Venceslao, 2008) En otras palabras, "el cambio del sujeto es efecto del cambio de lugar, esto es, de la promoción social que pueda provocar la acción educadora". (Núñez, op.cit:112)

Sabemos que sin el consentimiento del sujeto la acción educativa no es posible. Si éste no desea o consiente apropiarse del legado que se le ofrece, y elaborar con él, nuevas articulaciones culturales y sociales, la tarea de los profesionales será del todo infructuosa. Retomemos una vez más dos proposiciones filosóficas imprescindibles para el trabajo social educativo:

1. La idea hegelinana por la cual la voluntad del hombre no puede ser violentada. (1993 [1832]) El ser humano puede ser sojuzgado, en sus aspectos físicos y exteriores. Sin embargo, su voluntad es libre, esto es, no puede ser violentada ni forzada. "Sólo se puede obligar a algo a quien quiere ser obligado". (FD § 91)

2. El concepto kantiano de moralidad ligado a la imposibilidad de coacción de la moral. (2007 [1788]:36-37) "La voluntad (...) por su constitución subjetiva, no es

${ }^{56}$ Es precisamente la existencia de esta realidad subjetiva que hace al sujeto singular y único, marcando así la necesidad de trabajar atendiendo su particularidad. 
determinada necesariamente por tal ley", esto es, no admite constricción alguna. Estas premisas nos conducen a otro de los puntos medulares del modelo de trabajo que tratamos de esbozar. A saber: no es posible obligar a los jóvenes a que consientan al acto educativo. Movilizar su aquiescencia requiere, entre otras cosas, la apertura de tiempos y lugares que alberguen sus intereses (dando espacio y crédito a su palabra), permitiendo a su vez la emergencia de nuevas inquietudes. Es necesario a su vez, prestar atención a qué tipo de contenidos se ofrecen (socialmente valiosos), y a la posición que ocupa el encargado de trasmitirlos: un lugar de respeto, escucha, acompañamiento, pero también de exigencia... Un emplazamiento que convoca al joven a un lugar de responsabilidad y de posibilidad. Lograr el consentimiento de los jóvenes deviene uno de los desafíos más arduos e intrincados del trabajo educativo. La tarea del educador para conectar los intereses de los chavos con "posibles formas de realización social, es decir, trabajar para que el joven pueda encauzarlos de modos socialmente admitidos o admisibles" abre posibilidades inéditas de activar el asentimiento de jóvenes. "Se trata de legitimar sus intereses, proporcionando los recursos culturales para que pueda llegar a un despliegue, socialmente valioso, de aquellos". (Núñez, 1999:52)

Imaginamos y proponemos modelos institucionales que brinden a cada joven un lugar apreciado, plural y reconocido, en el que su palabra y su subjetividad puedan alojarse. Lugares atravesados por la cultura, que devengan plataformas de anclaje desde donde emprender nuevos e insospechados viajes a bordo de un Argos pertrechado de saberes que les permitan descifrar algo de la complejidad y del enigma del mundo. Modos de hacer que se desarrollen, como propone Diker (2004:8), junto con los chicos que transitan las instituciones, y no sobre ellos. O al decir zambraniano, hablando más con los adolescentes, y no tanto sobre ellos. (citada en Larrosa y Fenoy, 2002) Escuchándolos, sosteniéndolos, acompañándolos en sus búsquedas, al mismo tiempo que exigiéndoles. Un modelo que contemple a los jóvenes, no como personas deficitarias a las que hay que salvar, redimir o, en el mejor de los casos, auxiliar, sino como actores con 
pleno derecho a un lugar social. Un modelo que entiende la educación como el derecho de todo sujeto a formar parte, a ser inscrito en el entramado social, cultural y económico de su tiempo. 


\section{CAPÍTULO IV}

\section{PALABRAS FINALES...}

Aquí finaliza nuestro recorrido, siempre inconcluso, por las intrincadas geografías de la negatividad de los seres que representan la parte oscura y desordenada de toda sociedad. Son varios los aspectos que merecen ser destacados a modo de corolario en este itinerario final.

Las premisas sobre las que se ha construido la arquitectura general de la investigación nos han aproximado a la efigie amenazante de los desviados, no desde su concepción como fenómeno natural, sino como producto de dinámicas sociales y posiciones ideológicas entroncadas en el control y la exclusión de quienes parecen representar un peligro para lo que le Goff (2008:175) llamó la "comunidad sagrada", los normales. Como dispositivo conceptual, la anomalía social permite proyectar y fijar en los extraños todos los males de los que trata de alejarse. Hemos visto que esta construcción es reflejo de los miedos que la sociedad experimenta. Fuente de desorden y contaminación, los excluidos ocupan un lugar paradójicamente central en todas las sociedades: son la sustancia generadora por excelencia a partir de la cual se organiza y re-estructura la vida colectiva. Recordemos uno de los axiomas principales que han orientado este trabajo: todo orden se constituye a partir de una exclusión. (Tizio, 1997)

El imaginario social sitúa la existencia amenazante de los excluidos en contra del orden de la comunidad, por lo que se vuelve imprescindible vigilar y tutelar la presencia monstruosa y amenazante de esos otros que concitan nuestros miedos, fascinaciones y espantos. Cada sociedad, en cada momento histórico, ha confeccionado las categorias necesarias para designar y clasificar a aquellos que perturban el orden social, asi como los aparatos destinados a su gestión. Esta investigación ha centrado su mirada en una de las múltiples y multiplicadas modalidades contemporáneas de nombrar y operar sobre la desviación: la figura del "menor infractor" en su transitar por las redes institucionales (no carcelarias) de 
la justicia juvenil. Recorrido que nos ha permitido un acercamiento a la re-edición de las viejas prácticas de gestión poblacional higienista $-y$ su correlato de conceptualizaciones positivistas- como parte del utillaje al servicio de los nuevos modelos de control social de las invariables "clases peligrosas": los pobres. Hemos visto al mismo tiempo como los mecanismos de clasificación, y su correlato de nomenclaturas lógico-sociales, son instrumentos cognitivos, al mismo tiempo, que dispositivos de poder que ordenan, separan e inmovilizan grupos sociales, delineando diferencias y fronteras muchas veces inexpugnables.

Otra de nuestras consideraciones ha girado en torno a la lógica devaluativa del otro pobre que subyace en el higienismo contemporáneo, y que sella el nexo aparentemente inapelable entre pobreza y desviación. Esta postura encierra la idea de que la pobreza es, no sólo una condición social, sino una determinación, un atributo que define a los jóvenes que viven situaciones de pauperización. El sujeto, por el hecho de vivir en un entorno de marginación, es portador de un déficit económico, social, cultural, cognitivo y moral, quedando así justificada su cosificación como objeto de re-educación, esto es, alguien sobre el que intervenir con propósitos correctivos y reformadores. El "menor infractor" será impugnado y coaccionado para someterlo a un proceso de optimización que lo convierta en una "mejor persona", esa alucinación positivista por la que es posible acceder al "interior" del otro y transformarlo sin su consentimiento y voluntad. Durante el tratamiento será aleccionado con el profuso inventario de las "habilidades sociales" y los "valores" que mágicamente corregirán toda conducta juzgada como errada y perniciosa no sólo para el propio sujeto, sino también para el conjunto la sociedad. Esta catequización laicizada en valores y destrezas sociales desplaza los saberes culturales, para dar lugar a un trabajo educativo de corte moralizante, travestido de "empatías", "autoestimas", "emociones" y otras bondades. Lo que encontramos en lugar de la transmisión de saberes valiosos que posibiliten nuevos recorridos y anclajes en el entramado social -la tarea propiamente educativa- es un dispositivo de sujeción a un destino social prefijado. Las instituciones neohigienistas son horadadas por una suerte de vaciamiento cultural que nos 
remite indefectiblemente a la vigencia de las viejas posiciones educativas pestalozzianas, aquellas diseñadas a la medida de la pobreza y la exclusión de quien las recibe.

Estas arquitecturas ideológicas han marcado otro de los abordajes inexcusables de nuestra investigación. A saber: las prácticas de estigmatización y su corolario inferiorizante. El trabajo etnográfico ha evidenciado que la mirada de los profesionales es atravesada acríticamente por las representaciones hegemónicas sobre cómo deben ser los desviados. La categoría "joven delincuente" cuenta con sus "inherencias" particulares que contribuyen a forjar una determinada construcción (a priori) del otro. Nos topamos con un proceso de totalización de estos jóvenes a partir de las marcas distintivas y abyectas "menor infractor" y "joven de conducta problemática", otorgándoles así una nueva identidad que absorbe e invisibiliza el resto de aspectos que hacen particular y único a cada sujeto. Podríamos decir que la posesión de este rasgo desviado los esencializa, esto es, los supone poseedores de otros rasgos indeseables supuestamente asociados a su mácula principal. Los chavos pasan a ser la encarnación de una categoría social que los define más allá de sí mismos. Bajo esta lógica, el sujeto no depara ninguna sorpresa para los "operadores"; tampoco ningún enigma. Es trasparente a su mirada y previsible en sus conductas, pues todos aquellos apresados en esta misma categoría responden a un patrón idéntico de comportamiento. No sin cierta inquietud hemos advertido que estas posiciones de hermetismo y certidumbre (en relación a quién es el joven, y a las categorías omniexplicativas que guian las intervenciones de los profesionales) constituyen uno de los principales escollos para la tarea educativa, enemiga por definición de lo definitivo, lo imposible y lo determinado.

Las prácticas nominativas a las que nos referimos -retóricas que etiquetan, al mismo tiempo que sentencian y predisponen- terminan creando una realidad propia. El "discurso, en tanto proceso de producción de sentido, produce efectos de realidad" (Núñez, 2004b:125), representaciones y significaciones que crean 
imágenes y símbolos con consecuencias reales en el plano social, institucional, pero también en el subjetivo. Las inestimables contribuciones de los sociólogos del labelling approach nos han permitido abordar las prácticas de identificación de estos jóvenes y los mecanismos que conspiran para conformarlos a la imagen que los otros esperan de ellos. Así, los marcados con un atributo defectuoso acaban aprendiendo los términos de su inferioridad, esto es, el "joven problemático" acaba convirtiéndose en lo que dicen de él que es... acaba "problematizándose", adoptando la identidad que los demás le atribuyen y actuando como tal. Debemos volver a subrayar una vez más que estas cuestiones sintomáticas son producidas por el propio funcionamiento institucional. Retomemos a de Leo (1985:14) quien compendia perspicazmente estas cuestiones al argüir que las instituciones de justicia para menores son uno de los aspectos medulares de la criminalización de los jóvenes en el sentido que su acción "desempeña un papel primordial en la definición, delimitación, elaboración y producción social e institucional del fenómeno".

Uno de sus puntos medulares de la investigación se ha articulado en torno a los modos en los que los jóvenes habitan su tránsito institucional y las tramas de sentido que urden en relación al intento redentor del otro. En este sentido, la idea turneana de liminalidad $(1988,2007)$, propia de los ritos de paso, nos ha permitido realizar una primera aproximación a la interpretación que los chicos hacen del encargo institucional. Observamos que el tratamiento es concebido como un proceso transicional al que deben responder, esto es, un itinerario de mejoramiento en el que deben dar cuenta a los profesionales de que se están despojando de su antiguo ser (errado, incorrecto, infractor) para ocupar una nueva condición: la de normal. El trabajo etnográfico ha evidenciado, por un lado, que los chicos saben que lo que se pretende con su paso por la institución es una reubicación moral, un tránsito purificador que los incorpore a un nuevo orden moral; una suerte de itinerario exorcizante que los despoje de los viejos sentidos, para instalar otros; brete en el que se eliminarán y borrarán los antiguos atributos que los hacían "malos", para metamorfosearse en chicos "buenos". Por otro lado, 
nos ha permitido considerar sus respuestas al tratamiento en tanto actuación dramatúrgica en la que los chavos tratan de dar cuenta no sólo del consentimiento a ser "operados", sino de la incorporación a un nuevo orden moral gracias a la intervención de los profesionales. Retomaremos en breve este aspecto cardinal.

Hemos señalado que el ingreso a los circuitos de la justicia para menores, y sus mecanismos de producción de sujetos de "conducta problemática", atribuyen a los portadores de esta marca un nuevo estatus que modela sus prácticas de identificación al permear en el plano subjetivo. Sin embargo, aún en condiciones en las que los dispositivos de etiquetamiento despliegan su implacable capacidad estigmatizadora, registramos en los chicos operaciones de sujetivación que les permiten una cierta desvinculación de máculas abyectas, un atemperamiento de los efectos del estigma. Dicho de otro modo, los designios recalificadores no logran colonizarlos del todo. Lejos de enfrentarnos a un sujeto construido por y desde el poder, nos hemos topado con jóvenes con capacidad de resistencia contra la propedéutica reformatoria de la entidad.

A partir de la inmersión en lo tangible propia del trabajo de campo, y fondeando en las premisas teóricas de de Certeau (op.cit.), hemos tratado de exhumar las formas subrepticias que adquiere la creatividad táctica de los jóvenes atrapados en los circuitos institucionales de la "reeducación" y la "reinserción" social. Sujetos que no están inermes, ni mucho menos indiferentes, ante los intentos de asignación de una nueva identidad deteriorada. Por el contrario, hilan astucias, elaboran artimañas, tejen simulacros de adaptación que contrarrestan, sin aplacarla del todo, la maquinaria de sometimiento y marcaje institucional... Lo que hemos encontrado en nuestra exploración es un interesante despliegue de prácticas de subjetivación (Duschatzky y Corea, op.cit.) que les permiten contrarrestar la praxis denigratoria, articulando respuestas (subrepticias) en las que nos recuerdan que, lejos de ser "objetos" a corregir, son sujetos con capacidad de elección, decisión y deseo. 
Asimismo, no podemos dejar de mencionar en este tramo conclusivo que, en el recorrido por las geografías del higienismo contemporáneo, no todo ha sido infierno. A pesar de los intentos reformatorios y recalificadores de la institución, hemos constatado la existencia de espacios que, aunque minúsculos, permiten la emergencia de los chavos en tanto sujetos. Los chicos encuentran en la institución pequeños deltas; puntos donde anclarse para no ser arrastrados del todo por las corrientes de licuefacción que horadan nuestro tiempo. Y es que, como plantean Duschatzky y Corea (op.cit.:74), en un momento histórico atravesado por la ausencia de referentes a los que sujetarse, lo propio es que cualquier sistema de referencias que se arme conlleve la oportunidad de un proceso subjetivante. La aproximación etnográfica muestra la existencia de espacios que hacen posible la producción de estas operaciones de subjetivación, donde los jóvenes emergen, no como tabula rasa sobre la que operar, sino como sujetos con inquietudes, elecciones e intereses. Asimismo, constatamos que estos lugares vienen atravesados por el saber y la palabra, dos elementos entroncados en la práctica educativa.

Llegamos con estas inferencias a un punto crucial de la investigación: el encuentro entre la antropología y pedagogía social. Ha sido a través del análisis etnográfico de los tránsitos institucionales de estos jóvenes, que hemos podido abrir interrogantes acerca de qué modelo de trabajo educativo puede albergarlos en tanto sujetos con derecho a un lugar social.

Nos ha incardinado en esta apuesta el vasto utillaje de una pedagogía social disidente del control disciplinario y la gestión poblacional. Una pedagogía que analiza, problematiza y trasforma las prácticas sociales educativas encaminadas a la incorporación de los sujetos a la cultura de su tiempo, a través de la transmisión de aquellos saberes socialmente necesarios que les permitan inscribirse y circular por el entramado de su época. Sabemos que para posibilitar que algo de otro orden pueda nacer, esto es, para que el sujeto pueda habitar un por-venir, trazar sus propios recorridos y disponer de nuevos tiempos y lugares, es necesario 
acercarlo a la cultura y ofrecerle sus artilugios simbólicos como llaves de acceso a nuevas e insospechadas filiaciones sociales. Desde este lugar, la tarea educativa se convierte en resorte que incite a los jóvenes a emprender viajes impredecibles que los alejen de los lugares que conducen a lo determinado y lo definitivo.

Esta investigación ha intentado ofrecer una perspectiva distinta del fenómeno de la exclusión y sus modalidades de gestión, interrogándose a cerca de la validez de las taxonomías clasificatorias que inferiorizan al otro diferente, y revelando las arquitecturas ideológicas sobre la cuales está construida. Dando cuenta de la existencia de conocimientos y categorías que humillan y desprecian, hemos tratado de desentrañar el proceso de producción de ese otro "problemático", "infractor", "menor"... trazando líneas de reflexión que hagan posible una nueva representación de los jóvenes, no ya como problema social a gestionar, sino como sujetos con derecho a ser injertados en el entramado social de su época. Deseamos que esta investigación haya contribuido a la apertura de nuevos y valiosos espacios para el trabajo social educativo que, alejado del infierno, formen parte fundamental del engranaje que convoca y robustece la justicia social. 


\section{BIBLIOGRAFÍA}

\section{Agamben, Giorgio}

2006 Homo sacer. El poder soberano y la nuda vida. Valencia: Pre-textos.

\section{Arendt, Hannah}

1996 La crisis de la educación en Entre el pasado y el futuro. Barcelona: Península.

2004 Los orígenes del totalitarismo. Barcelona: Taurus.

\section{Ayciriex, Aurora, y Victoria Moretti}

2004 Por las cornisas del diagnóstico en Una ética en el trabajo con niños y jóvenes. La habilitación de una oportunidad. G. Frigerio y G. Diker, eds. Pp. 58-64. Buenos Aires: Novedades educativas.

\section{Balandier, George}

1994 El poder en escena. De la representación del poder al poder de la representación. Barcelona: Paidós.

\section{Baratta, Alessandro}

2004 Criminología crítica y crítica del derecho penal. Barcelona: Siglo XXI.

Barth, Frederik

1976 Los grupos étnicos y sus fronteras. México D.F.: FCE.

\section{Bauman, Zygmunt}

1999 Trabajo, consumismo y nuevo pobres. Barcelona: Gedisa.

2002 Modernidad líquida. México D.F.: FCE.

2004 Vidas desperdiciadas. La modernidad y sus parias. Buenos Aires: Paidós.

2005 Amor líquido. Acerca de la fragilidad de los vínculos humanos. Buenos Aires: FCE. 


\section{Becker, Howard S.}

1971 Los extraños. Sociología de la desviación. Buenos Aires: Tiempo contemporáneo.

Bentham, Jeremy

1979 El panóptico. Madrid: La Piqueta.

Bergalli, Roberto, Juan Bustos Ramírez, y Miralles Teresa

1983 El pensamiento criminológico. Volume I. Bogotá: Temis.

Berger, Peter, y Thomas Luckmann

2001 La construcción de la realidad social. Buenos Aires: Amorrortu.

Bernfeld, Siegfried

1973 Psicoanálisis y educación antiautoritaria. Barcelona: Barral.

Calvino, Ítalo

2003 Las ciudades invisibles. Madrid: Siruela.

Castel, Robert

1984 La gestión de los riesgos: de la antipsiquiatría al post-análisis. Barcelona: Anagrama.

2004aEl encuadre de la exclusión en La exclusión: bordeando sus fronteras. Definiciones y matices. S. Karsz, ed. Barcelona: Gedisa.

2004b La inseguridad social. ¿Qué es estar protegido? Buenos Aires: Manantial. Castellanos, Francisco

2007 Manual de capacitadores: Las medidas en la justicia para adolescentes.

Certeau, Michel de

2007 La invención de lo cotidiano. Artes de hacer. México D.F.: Universidad Iberoamericana.

Cohen, Stanley

1988a Visiones de control social

Barcelona: PPU.

1988b Visiones de control social. Barceona: PPU. 


\section{Cornu, Laurence}

2004 La ética de una oportunidad en Una ética en el trabajo con niños y jóvenes. La habilitación de una oportunidad. G. Frigerio y G. Diker, eds. Pp. 14-32. Buenos Aires: Novedades educativas.

\section{Chapman, Dennis}

1968 Sociology and the stereotype of the criminal. London: Tavistock.

\section{Delgado, Manuel}

2007 Sociedades movedizas. Pasos hacia una antropología de las calles. Barcelona: Anagrama.

Díaz, R., y G. Hillert

1993 El tren de los adolescentes. Buenos Aires: Lumen Humanitas.

\section{Diker, Gabriela}

2004 Los sentidos de las nociones de prácticas y experiencias en Una ética en el trabajo con niños y jóvenes. La habilitación de una oportunidad. G. Frigerio y G. Diker, eds. Pp. 8-13. Buenos Aires: Novedades Educativas.

\section{DOF}

24 de diciembre de 1991.

\section{Douglas, Mary}

1978 Símbolos naturales. Madrid: Alianza.

1991a Brujería: el estado actual de la cuestión en Ciencia y brujería. M. Gluckman, ed. Barcelona: Anagrama.

1991bPureza y peligro. Un análisis de conceptos de contaminación y tabú. Madrid: Siglo XXI.

\section{Durkheim, Emile}

2006 [1895] Las reglas del método sociológico. México D.F.: Colofón.

\section{Durkheim, Emile, y Marcel Mauss}

1996 [1901] Sobre algunas formas primitivas de clasificación. Contribución al estudio de las representaciones colectivas. Barcelona: Ariel. 


\section{Duschatzky, Silvia, y Cristina Corea}

2007 Jóvenes en banda. Los caminos de la subjetividad en el declive de las instituciones. Barcelona: Paidós.

\section{Forrester, Viviane}

1997 El horror económico. México D.F.: FCE.

Foucault, Michel

1970 Arqueología del saber. Méxio, D.F.: Siglo XXI.

1980 Historia de la sexualidad, vol. 1. Madrid: Siglo XXI.

1994 Nacimiento de la biopolítica. Buenos Aires: Siglo XXI.

2000a Los anormales. México, D. F.: FCE.

2000b Vigilar y castigar. Madrid: Siglo XXI.

\section{Gallén, Carlota}

2006 Les fronteres de la normalitat. Una aproximació en clau social a les persones amb intel-ligència límit o borderline. Barcelona: Edicions de 1984.

Goff, Jaques Le

2008 Lo maravilloso y lo cotidiano en el Occidente medieval. Barcelona: Gedisa.

Goffman, Erving

2003 Estigma. Madrid Amorrortu.

2004a Internados. Ensayos sobre la situcación social de los enfermos mentales. Madrid: Amorrortu.

2004b La presentación de la persona en la vida cotidiana. Madrid Amorrortu.

\section{Gónzalez Echevarría, Aurora}

1984 Invención y castigo del brujo en el África negra. Teorias sobre la brujería. Barcelona: Serbal. 
Gónzalez Vidaurri, Alicia, y Augusto Sánchez Sandoval

2008 Criminología. México D.F.: Porrúa.

Gramsci, Antonio

1973 La alternativa pedagógica. Barcelona: Nova Terra.

Hegel, Georg Wilhelm Friedrich

1993 [1832] Fundamnetos de la Flilosofía del Derecho. Madrid: Libertarias Prodhufiy

Jiménez, García

2009 <http://www.juridicas.unam.mx/publica/rev/boletin/cont/95/el/el14.htm\#N3>:

Revista Jurídica. Boletín Mexicano de Derecho Comparado

Juliano, Dolores

2002 La prostitución: el espejo oscuro. Barcelona: Icaria.

Kant, Immanuel

2007 [1788] Crítica a la razón práctica. México D.F.: Porrua.

Karsz, Saul

2004 La exclusión: concepto falso, problema verdadero en La exclusión: bordeando sus fronteras. Definiciones y matices. S. Karsz, ed. Barcelona: Gedisa.

2007 Problemática del trabajo social. Definición, figuras, clínica. Barcelona: Gedisa.

Krotz, Esteban

2007 Cuatro cuestiones cruciales para el desarrollo de nuestras antropologías en ¿A dónde va la antropología? A. Giglia y C. Garma, eds. México D.F.: Alteridades. Larrauri, Elena

2000 La herencia de la criminología crítica. Barcelona: Siglo XXI.

Larrosa, Jorge, y Sebastián Fenoy

2002 María Zambrano: el arte de las mediaciones. Barcelona: Publicaciones de la Universidad de Barcelona.

Leach, Edmund

1985 Cultura y comunicación : la lógica de la conexión de los simbolos. Una introducción al uso del análisis estructuralista en la antropología social. México D.F.: Siglo XXI. 


\section{Lemert, Edwin}

1967 Human deviance, social problems and social control. Englewood Cliffs: N.J. Prentice-Hall.

Leo, Gaetano de

1985 La justicia de menores. Barcelona: Teide.

\section{Lévi-Strauss, Claude}

1971 Introducción a la obra de Marcel Mauss en Sociología y Antropología. M. Mauss, ed. Madrid: Tecnos.

1982 El pensamiento salvaje. México D.F.: FCE.

\section{Malinowski, Bronislaw}

1973 [1922] Los argonautas del pacífico occidental. Barcelona: Península.

\section{Matza, David}

1981 El proceso de desviación. Madrid: Taurus.

\section{Meirieu, Philiphe}

1998 Frankenstein educador. Barcelona: Laestes.

\section{Moore, Sally F.}

1978 Law as process. London: Routledge \& Kegan Paul Ltd.

\section{Moreno, Luis}

2000 Ciudadanos precarios. La "última red" de protección social. Barcelona: Ariel.

\section{Núñez, Violeta}

1990 Modelos de educación social en la época contemporánea. Barcelona: PPU.

1999 Pedagogía social: cartas para navegar en el nuevo milenio. Buenos Aires: Santillana.

2003 Los nuevos sentidos de la tarea de enseñar. Más allá de la dicotomía "enseñar vs. asistir". Revista Iberoamericana de Educación nº 33. 
2004a La pedagogía social y el trabajo educativo con las jóvenes generaciones en Una ética en el trabajo con niños y jóvenes. La habilitación de una oportunidad. G.y.D. Frigerio, Gabriela ed. Pp. 110-120. Buenos Aires: Novedades educativas.

2004b Viejos y nuevos paradigmas... ¿qué pasa en la Pedagogía Social? Pedagogía Social. Revista interuniversitaria n 11:pp. 111-134.

2005 Participación y educación social. en XVI Congreso Mundial de Educadores Sociales. Montevideo.

Núñez, Violeta, y Teresa Planas

1997 La educación social especializada. Historia y perspectivas: una propuesta metodológica en Pedagogía social. A. Petrus, ed. Barcelona: Ariel.

Paz, Octavio

1993 El laberinto de la soledad. México D.F.: FCE.

Platt, Anthony M.

1974 The child savers. The invention of delinquency. Chicago: The University of Chicago Press.

\section{Reguillo, Rossana}

2005 Ciudades y violencias. Un mapa contra los diagnósticos fatales en Ciudades translocales: espacios, flujos, representaciones. Perspectivas desde las américas. S. Reguillo y M. Godoy, eds. Tlaquepeque (México): ITESO.

2007 La mara: conteingencia y afiliación con el exceso (re-pensando los límites) en Las maras. Identidades juveniles al límite. J.M. Valenzuela, A. Nateras, y R. Reguillo, eds. México D.F.: UAM, C.C. CAsa Juan Pablo, Colegio de la Frontera Norte.

\section{Santamaría, Enrique}

2002 La incógnita del extraño. Una aproximación sociológica de la "inmigración no comunitaria". Barcelona: Anthropos.

\section{Schechner, Richard}

1985 Between theater and anthropology. Philadelphia: University of Pennsylvania Press. 


\section{Simmel, George}

1971 [1908] "The poor" en Georg Simmel on individuality and social forms. Chicago: University of Chicago press.

\section{Thomas, Elisa, y Marta Venceslao}

2008 Itinerarios de inserción laboral: una propuesta de promoción social. Revista del Colegio de Educadores y Educadoras Sociales de Catalunya (CEESC) n 11.

Tizio, Hebe

1997 La categoría inadaptación social en Pedagogía social. A. Petrus, ed. Barcelona: Ariel.

2008 El protocolo y las reglas de la práctica. $V$ debate de actualidad ELP-CdC "Abusos del protocolo", Barcelona, 2008.

\section{Turk, Austin}

1969 Criminality and the legal order. Chicago: Rand Mc Nally \& Co.

\section{Turner, Victor}

1988 El proceso ritual. Madrid: Taurus.

2007 La selva de los símbolos. México D.F.: Siglo XXI.

\section{Van, Gennep Arnold}

1986 Los ritos de paso. Madrid: Taurus.

\section{Vergara, Abilio}

2006 El resplandor de la sombra. México D.F.: Educiones Navarra.

Wallerstain, Inmanuel

2006 Análisis del sistema mundo. México D.F.: Siglo XXI. 